\title{
Radioactive Air Emissions Notice of Construction Application for the Waste Receiving and Processing Facility
}

Prepared for the U.S. Department of Energy

Assistant Secretary for Environmental Management

Project Hanford Management Contractor for the

U.S. Department of Energy under Contract DE-AC06-96RL13200

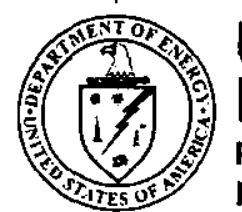

United States

Department of Energy

P.o. Box 550

Richland, Washington 99352 


\section{INFORMATION CLEARANCE FORM}

A. Information Category

$\square$ Abstract

$\square$ Journal Article

$\square$ Summary

$\square$ Internet

$\square$ Visual Aid

$\square$ Soltware

$\square$ Full Paper

Other

$\square$ Report

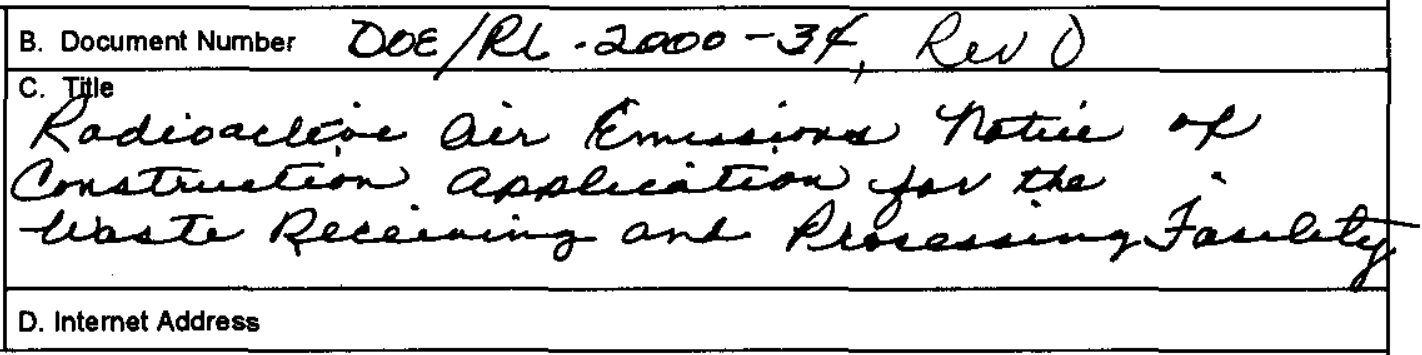

E. Required Information

1. Is document potentialy classified? QTo OYes (MANDATORY)

\section{Rif. Eoghe \\ Manager's Signature Required}

If Yes

ADC Signature Required

2. Internal Review Required?

If Yes, Document Signatures Below

DNo Ores Classified

QNo OYes

Counsel

Program

3. References in the Information are Applied Technology (No OYes

Export Controlled Information ONo OYes
4. Does Information Contain the Following: (MANDATORY)

a. New or Novel (Patentable) Subject Matter? DNo OYes

If "Yes", Disclosure No.:

b. Information Received in Confidence, Such as Proprietary and/or Inventions? QNo OYes If "Yes", Affix Appropriate Legends/Notices.

c. Copyrights? Qwo OYes If "Yes", Attach Permission.

d. Trademarks? ONo Qves If "Yes", Identify in Document.

5. Is Information requiring submission to OSTI? (B) $O$ Yes

If Yes UCand $B \& R-$

6. Release Level? (D) Public O Limited

7. Charge code $8159 / 9$

F. Complete for a Journal Article

1. Title of Journal

G. Complete for a Presentation

1. Title for Conference or Meeting

2. Group Sponsoring

3. Date of Conference

5. Will information be Published in Proceedings? $\bigcirc$ No $O$ Yes

4. City/State

H. Author/Requestor

6. Will Material be Handed Out? $\bigcirc$ No $O$ Yes

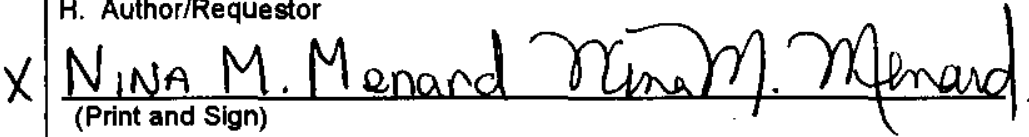
Responsible Manager

I. Reviewers

$\chi$

General Counsel

Lelend Eillis W

Office of Externat Affairs

DOE-RL

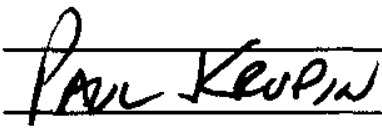

Signatua

$\square$

$X$

Other

$\square$

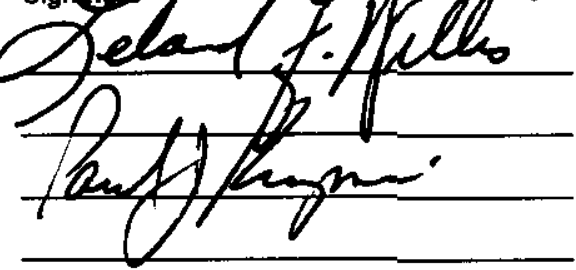

$\mathrm{Y} / \mathrm{N}$

$\mathrm{Y} / \mathrm{N}$

$\mathrm{Y} / \mathrm{N}$

$\mathrm{Y} / \mathrm{N}$

Other

$\square$

$\mathrm{Y} / \mathrm{N}$

J. If Information Includes Sensitive Information and is not to be released to the Public indicate category below.

$\square$ Applied Technology $\square$ Protected CRADA

$\square$ Personal/Private $\square$ Export Controlled

$\square$ Proprietary $\square$ Procurement-Sensitive

$\square$ Business-Sensitive $\square$ Patentable

$\square$ Predecisional $\square$ Other (Specify)

$\square$ UCNI

K. If Additional Comments, Please Attach Separate Sheet

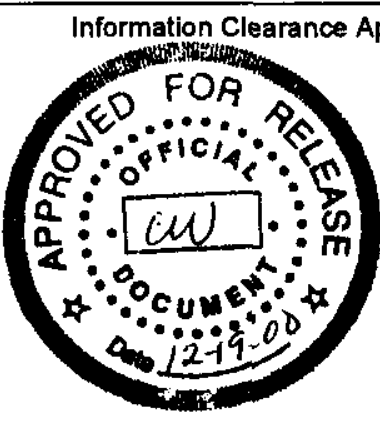




\section{Radioactive Air Emissions Notice of Construction Application for the Waste Receiving and Processing Facility}

Date Published

December 2000

Prepared for the U.S. Department of Energy

Assistant Secretary for Environmental Management

Project Hanford Management Contractor for the

U.S. Department of Energy under Contract DE-AC06-96RL13200

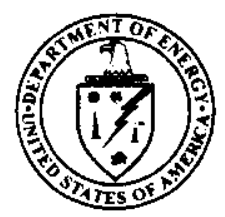

United States Department of Energy

P.O. Box 550

Richland, Washington 99352

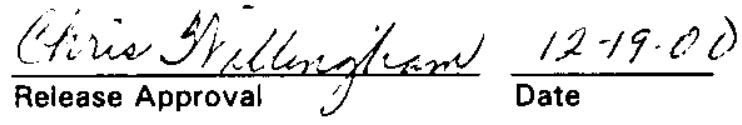




\section{LEGAL DISCLAIMER}

This report was prepared as an account of work sponsored by an agency of the United States Government. Neither the United States Government nor any agency thereof, nor any of their employees, nor any of their contractors, subcontractors or their employees, makes any warranty, express or implied, or assumes any legal liability or responsibility for the accuracy, completeness, or any third party's use or the results of such use of any information, apparatus, product, or process disclosed, or represents that its use would not infringe privately owned rights. Reference herein to any specific commercial product, process, or senvice by trade name, trademark, manufacturer, or otherwise, does not necessarily constitute or imply its endorsement, recommendation, or favoring by the United States Government or any agency thereof or its contractors or subcontractors. The views and opinions of authors expressed herein do not necessarily state or reflect those of the United States Government or any agency thereof.

This report has been reproduced from the best available copy.

Printed in the United States of America 
TERMS

METRIC CONVERSION CHART.

NOTICE OF CONSTRUCTION HISTORY

1.0 LOCATION

2.0 RESPONSIBLE MANAGER

3.0 PROPOSED ACTIONS

4.0 STATE ENVIRONMENTAL POLICY ACT

CHEMICAL AND PHYSICAL PROCESSES

5.0

5.1

5.2

5.3

5.3 .1

5.3 .2

5.3 .3

5.3 .4

6.0

6.1

6.1 .1

6.1 .2

6.1 .3

6.2

6.2 .1

6.2 .2

6.3

7.0

8.0

40

SHIPPING AND RECEIVING.

PROCESS AREA.

Transuranic Waste Process Line.

Transuranic Waste Restricted Waste Management Line

Low-Level Waste Process Line.

NONDESTRUCTIVE EXAMINATION/NONDESTRUCTIVE ASSAY SYSTEMS

Low-Level Waste Restricted Waste Management Process Line.

Hist-1

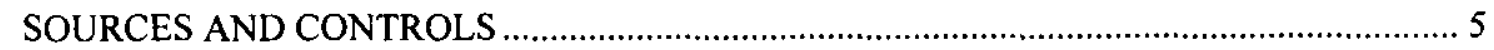

DESCRIPTION OF THE SOURCES

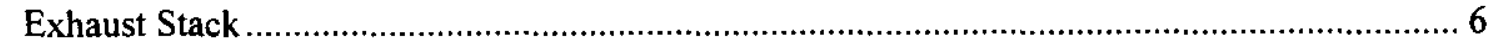

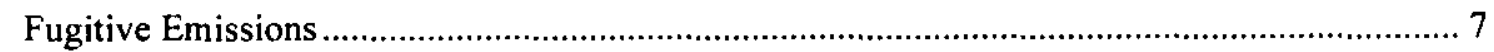

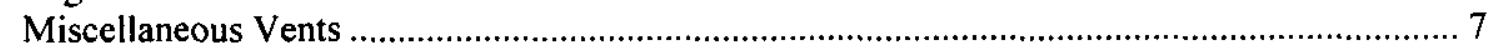

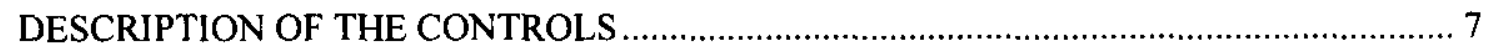

Description of Effluent System ...................................................................................... 8

Efficiency Values of The Control Devices for Removal of Radioactivity ............................... 8

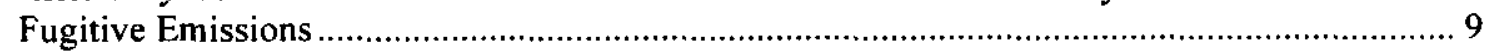

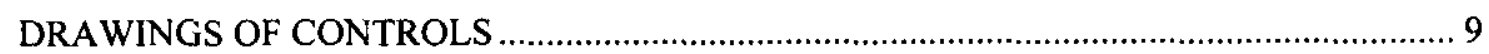

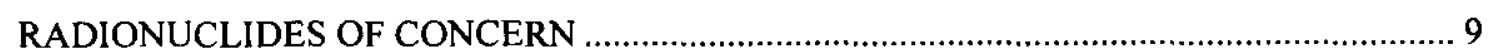

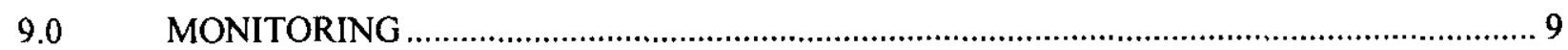

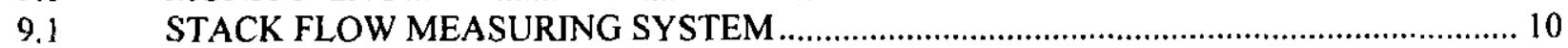

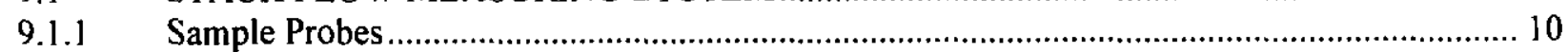

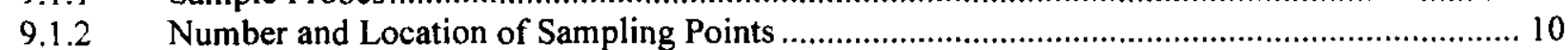

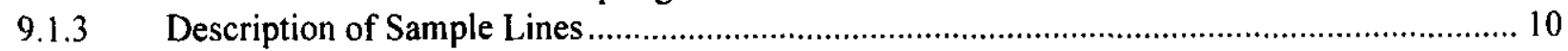

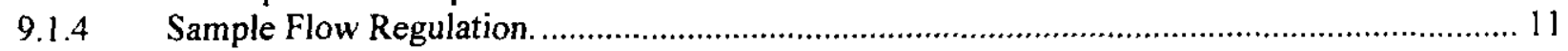

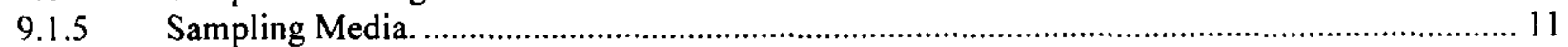

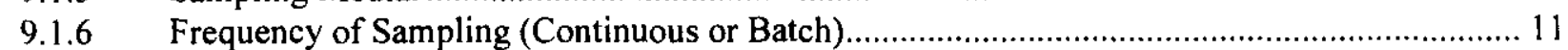

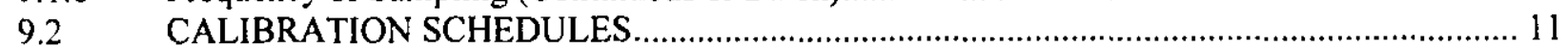

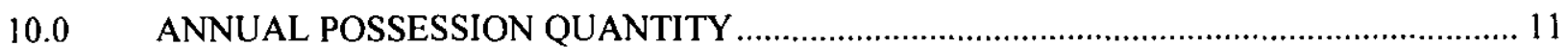




\section{CONTENTS (cont)}

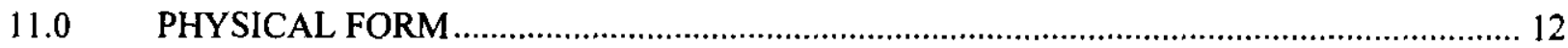

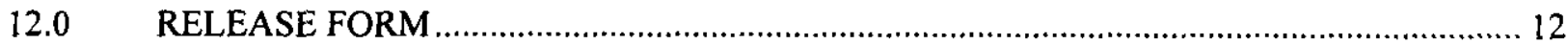

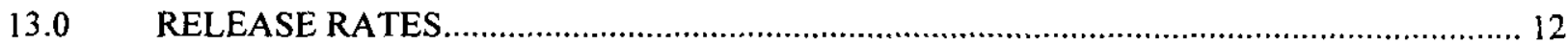

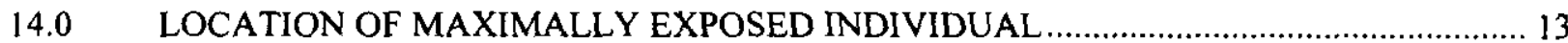

15.0 TOTAL EFFECTIVE DOSE EQUIVALENT TO THE MAXIMALLY EXPOSED

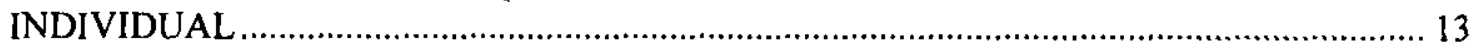

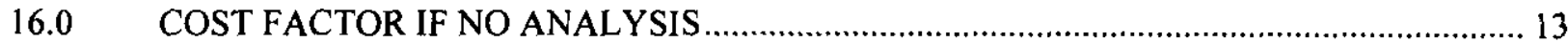

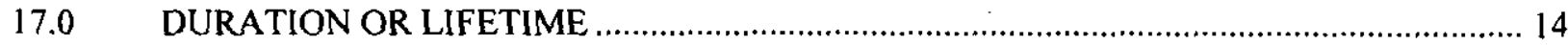

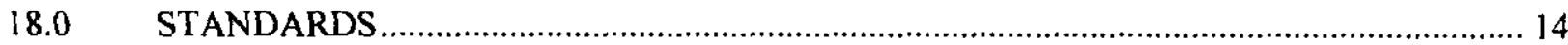

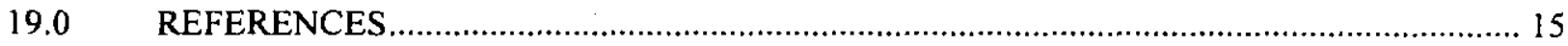

\section{ATT-1 CALCULATION OF DOSE FROM 200 WEST AREA TO} ONSITE MEMBER OF THE PUBLIC ATT $1-i$

ATT-2 CAP88-PC SYNOPSIS REPORT (1 OF 10) ............................................................ ATT-2-j

\section{FIGURES}

Figure 1. Hanford Site. $\mathrm{F}-1$

Figure 2. Location of the Waste Receiving and Processing Facility in the 200 West Area......................F-2

Figure 3. Waste Receiving and Processing Facility Floor Plan........................................................F-3

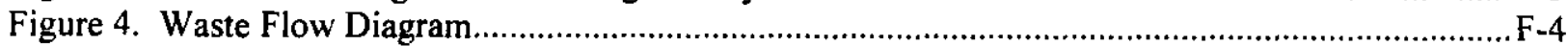

Figure 5. Flow Diagram through Transuranic Waste Gloveboxes. ..................................................F-5

Figure 6. Flow Diagram through Low-Level Processing Glovebox. ................................................F-6

Figure 7. Waste Receiving and Processing Facility Stack. ............................................................

Figure 8. Schematic of Zone I and Zone II Ventilation System......................................................

Figure 9. Waste Receiving and Processing Facility Stack Monitoring and Sampling Systems...............F-9 
BARCT

CFR

$\mathrm{CH}$

$\mathrm{Ci}$

DOE

DOE-RL

EDE

EPA

HEPA

HVAC

ISEMS

LLW

MEI

NDE/NDA

NOC

PNNL

PTE

RCRA

REDOX

RH

RTR

RWM

SEPA

TEDE

TRU

TRUPACT

WAC

WDOH

WC

WG

WIPP

WRAP

${ }^{\circ} \mathrm{C}$

\section{TERMS}

as low as reasonably achievable control technology

American National Standards Institute

American Society of Mechanical Engineers

annual possession quantity

best available radionuclide control technology

Code of Federal Regulations

contact handled

curie

U.S. Department of Energy

U.S. Department of Energy, Richland Operations Office

effective dose equivalent

U.S. Environmental Protection Agency

high-efficiency particulate air heating, ventilation, and air conditioning isokinetic stack emission monitoring system

low-level waste

maximally exposed individual

nondestructive examination/nondestructive assay notice of construction

Pacific Northwest National Laboratory potential to emit

Resource Conservation and Recovery Act of 1976

reduction and oxidation

remote handled

real-time radiography

restricted waste management

State Environmental Policy Act of 1971

total effective dose equivalent

transuranic (waste)

transuranic package transporter

Washington Administrative Code

Washington State Department of Health

water column

water gauge

Waste Isolation Pilot Plant

Waste Receiving and Processing Facility

degrees Centigrade 


\section{METRIC CONVERSION CHART}

Into metric units

Out of metric units

\begin{tabular}{|c|c|c|c|c|c|}
\hline If you know & Multiply by & To get & If you know & Multiply by & To get \\
\hline \multicolumn{3}{|c|}{ Length } & \multicolumn{3}{|c|}{ Length } \\
\hline inches & 25.40 & millimeters & millimeters & 0.0393 & inches \\
\hline inches & 2.54 & centimeters & centimeters & 0.393 & inches \\
\hline feet & 0.3048 & meters & meters & 3.2808 & feet \\
\hline yards & 0.914 & meters & meters & 1.09 & yards \\
\hline miles & 1.609 & kilometers & kilometers & 0.62 & miles \\
\hline \multicolumn{3}{|c|}{ Area } & \multicolumn{3}{|c|}{ Area } \\
\hline square inches & 6.4516 & $\begin{array}{l}\text { square } \\
\text { centimeters }\end{array}$ & $\begin{array}{l}\text { square } \\
\text { centimeters }\end{array}$ & 0.155 & $\begin{array}{l}\text { square } \\
\text { inches }\end{array}$ \\
\hline square feet & 0.092 & square meters & square meters & 10.7639 & square feet \\
\hline square yards & 0.836 & square meters & square meters & 1.20 & square yards \\
\hline square miles & 2.59 & $\begin{array}{l}\text { square } \\
\text { kilometers }\end{array}$ & $\begin{array}{l}\text { square } \\
\text { kilometers }\end{array}$ & 0.39 & square miles \\
\hline acres & 0.404 & hectares & hectares & 2.471 & acres \\
\hline \multicolumn{3}{|c|}{ Mass (weight) } & \multicolumn{3}{|c|}{ Mass (weight) } \\
\hline ounces & 28.35 & grams & grams & 0.0352 & ounces \\
\hline pounds & 0.453 & kilograms & kilograms & 2.2046 & pounds \\
\hline short ton & 0.907 & metric ton & metric ton & 1.10 & short ton \\
\hline \multicolumn{3}{|c|}{ Volume } & \multicolumn{3}{|c|}{ Volume } \\
\hline fluid ounces & 29.57 & milliliters & milliliters & 0.03 & fluid ounces \\
\hline quarts & $0 . \overline{95}$ & liters & liters & 1.057 & quarts \\
\hline gallons & 3.79 & liters & liters & 0.26 & gallons \\
\hline cubic feet & 0.03 & cubic meters & cubic meters & 35.3147 & cubic feet \\
\hline cubic yards & 0.76456 & cubic meters & cubic meters & 1.308 & cubic yards \\
\hline \multicolumn{3}{|c|}{ Temperature } & \multicolumn{3}{|c|}{ Temperature } \\
\hline Fahrenheit & $\begin{array}{l}\text { subtract } 32 \\
\text { then } \\
\text { multiply by } \\
5 / 9 \text { ths }\end{array}$ & Celsius & Celsius & $\begin{array}{l}\text { multiply by } \\
9 / 5 \text { ths, then } \\
\text { add } 32\end{array}$ & Fahrenheit \\
\hline \multicolumn{3}{|c|}{ Energy } & \multicolumn{3}{|c|}{ Energy } \\
\hline kilowatt hour & 3,412 & $\begin{array}{l}\text { British thermal } \\
\text { unit }\end{array}$ & $\begin{array}{l}\text { British thermal } \\
\text { unit }\end{array}$ & 0.000293 & $\begin{array}{l}\text { kilowatt } \\
\text { hour }\end{array}$ \\
\hline kilowatt & $0 . \overline{948}$ & $\begin{array}{l}\text { British thermal } \\
\text { unit per second }\end{array}$ & $\begin{array}{l}\text { British thermal } \\
\text { unit per second }\end{array}$ & $1 . \overline{055}$ & kilowatt \\
\hline \multicolumn{3}{|c|}{ Force/Pressure } & \multicolumn{3}{|c|}{ Force/Pressure } \\
\hline $\begin{array}{l}\text { pounds per } \\
\text { square inch }\end{array}$ & 6.895 & kilopascals & kilopascals & 0.14504 & $\begin{array}{l}\text { pounds per } \\
\text { square inch }\end{array}$ \\
\hline
\end{tabular}

Source: Engineering Unit Conversions, M. R. Lindeburg, PE., Second Ed., 1990, Professional

Publications, Inc., Belmont, California. 


\section{NOTICE OF CONSTRUCTION HISTORY}

The history of the Waste Receiving and Processing Facility Notice of Construction is ordered from the most recent changes to the original notice of construction document (DOE/RL-93-15, Rev. 0).

The initial "Application for Approval to Construct the Waste Receiving and Processing (WRAP) Facility" (DOE/RL-93-15, Rev. 0) was submitted to the Washington State Department of Health in February 1993, and approved by Washington State Department of Health on September 7, 1993.

In January and May of 1999, several (15) revisions to the Waste Receiving and Processing Facility Notice of Construction were approved by Washington State Department of Health. These revisions were made to more accurately reflect the actual operation of the Waste Receiving and Processing Facility and are as follows.

\section{DOE/RL-93-15, Rev. 0A (Air Operating Permit classification)}

Rev. 0A was an upgrade to the continuous air monitor equipment; concurrence received.

DOE/RL-93-15, Rev. 0B (Air Operating Permit classification)

\begin{tabular}{|l|l|}
\hline Date Approved & \multicolumn{1}{c|}{ Summary of Revisions } \\
\hline $1 / 20 / 1999 \mathrm{a}$ & $\begin{array}{l}\text { Changes the limitation on receiving only contact-handled waste to be able to } \\
\text { accept waste that would exceed this limit on a case-by-case basis. }\end{array}$ \\
\hline $1 / 20 / 1999 \mathrm{~b}$ & $\begin{array}{l}\text { This revision changes the description of the size of containers that could be } \\
\text { received by Waste Receiving and Processing Facility. }\end{array}$ \\
\hline $1 / 20 / 1999 \mathrm{c}$ & $\begin{array}{l}\text { The description of operations was modified to state that not all containers will } \\
\text { have been sampled before arriving at Waste Receiving and Processing Facility. } \\
\text { Waste Receiving and Processing Facility also will be sampling the waste as a part } \\
\text { of operations. This revision also clarifies that only the containers with transuranic } \\
\text { material will be vented through high-efficiency particulate air filters. }\end{array}$ \\
\hline $1 / 20 / 1999 \mathrm{~d}$ & $\begin{array}{l}\text { Revises the notice of construction to allow for the treatment of liquid drained } \\
\text { from aerosol cans. }\end{array}$ \\
\hline $1 / 20 / 1999 \mathrm{e}$ & $\begin{array}{l}\text { Revises the figure of the Waste Receiving and Processing Facility stack to } \\
\text { remove the spoilers for vortex shedding, which were never installed. }\end{array}$ \\
\hline $1 / 20 / 1999 \mathrm{f}$ & Revises the frequency of sample collection. \\
\hline $1 / 20 / 1999 \mathrm{~g}$ & Revises notice of construction to include a preventative maintenance schedule. \\
\hline $1 / 20 / 1999 \mathrm{~h}$ & Changes the material used to test the high-efficiency particulate air filters. \\
\hline
\end{tabular}


DOE/RL-93-15, Rev. 0C (Air Operating Permit classification)

2

\begin{tabular}{|l|l|}
\hline Date Approved & \multicolumn{1}{c|}{ Summary of Revisions } \\
\hline $5 / 4 / 1999 \mathrm{a}$ & $\begin{array}{l}\text { Clarifies the "Description of Operations" Section to indicate that housekeeping } \\
\text { waste, survey waste, etc., are not subject to the flow schematic in the figures. }\end{array}$ \\
\hline $5 / 4 / 1999 \mathrm{~b}$ & $\begin{array}{l}\text { Clarifies that containers could be opened in the Processing Area to loosen a lid or } \\
\text { replace a damaged lid. }\end{array}$ \\
\hline $5 / 4 / 1999 \mathrm{c}$ & $\begin{array}{l}\text { Removes the RWM acronym as it is not needed in the description and also } \\
\text { updates the Waste Isolation Pilot Plant acceptance criteria descriptions. }\end{array}$ \\
\hline $5 / 4 / 1999 \mathrm{~d}$ & $\begin{array}{l}\text { Updates the description of the areas where waste is handled in either a closed or } \\
\text { vented container to add the possibility of fugitive emissions. }\end{array}$ \\
\hline $5 / 4 / 1999 \mathrm{e}$ & $\begin{array}{l}\text { Revises the description of the shipping/receiving and nondestructive } \\
\text { examination/nondestructive assay areas to state that room generated waste always } \\
\text { will not be in closed containers. }\end{array}$ \\
\hline $5 / 4 / 1999 \mathrm{f}$ & $\begin{array}{l}\text { Adds a new section to describe the potential fugitive emissions from vented } \\
\text { containers in the shipping/receiving and nondestructive } \\
\text { examination/nondestructive assay areas. }\end{array}$ \\
\hline $5 / 4 / 1999 \mathrm{~g}$ & \begin{tabular}{l} 
This revision updates the list of radionuclides. \\
\hline
\end{tabular}
\end{tabular}

The Waste Receiving and Processing Facility began operation in April 1997. In a Routine Technical Assistance Meeting on April 21, 1998, additional information was submitted to the Washington State Department of Health with a more complete list of radionuclides that are within the source term. The additional radionuclides did not increase the potential to emit, nor were there any change in the operation or physical form. The Washington State Department of Health accepted the additional information as indicated by their signatures on the routine minutes for April 21, 1998.

On July 9, 1996 at a Routine Technical Assistance Meeting meeting, Washington State Department of Health approved the replacement of two continuous air monitors with one Berthold ${ }^{\oplus}$ continuous air monitor. The Washington State Department of Health approved this as a technology improvement and confirmed that no notice of construction would be required.

DOE/RL-93-16, Application for Approval to Construct the Waste Receiving and Processing Facility, Revision 0, was submitted to the U.S. Environmental Protection Agency on April 2, 1993; approval was received on May 10, 1993 (EPA 1993). No revisions have been made on this document.

\footnotetext{
${ }^{\circledR}$ Berthold is a registered trademark of Berthold Systems, Inc., Aliquippa, PA.
} 


\section{RADIOACTIVE AIR EMISSIONS NOTICE OF CONSTRUCTION APPLICATION FOR THE WASTE RECEIVING AND PROCESSING FACILITY}

This document serves as a notice of construction (NOC) pursuant to the requirements of Washington Administrative Code (WAC) 246-247-060, and as a request for approval to modify pursuant to 40 Code of Federal Regulations (CFR) 61.07 for the Waste Receiving and Processing (WRAP) Facility.

The rewrite of this NOC incorporates all the approved revisions (Sections 5.0, 6.0, 8.0, and 9.0), a revised potential to emit (PTE) based on the revised maximally exposed individual (MEI) (Sections 8.0, 10.0, $11.0,12.0,13.0,14.0$, and 15.0), the results of a study on fugitive emissions (Sections 6.0, 10.0, and 15.0 ), and reflects the current operating conditions at the WRAP Facility (Section 5.0). This NOC replaces DOE/RL-93-15 and DOE/RL-93-16 in their entirety.

The primary function of the WRAP Facility is to examine, assay, characterize, treat, verify, and repackage radioactive material and mixed waste. There are two sources of emissions from the WRAP Facility: stack emissions and fugitive emissions. The stack emissions have an unabated total effective dose equivalent (TEDE) estimate to the hypothetical offsite MEI of 1.13 E+02 millirem per year. The abated TEDE for the stack emissions is estimated at $5.63 \mathrm{E}-02$ millirem per year to the MEI. The fugitive emissions have an unabated TEDE estimate to the hypothetical offsite MEl of 5.87 E-04. There is no abatement for the fugitive emissions.

The following text provides the WAC 246-247, Appendix A, requirements 1 through 18.

\subsection{LOCATION}

Name and address of the facility, and location (latitude and longitude) of the emission unit(s).

The WRAP Facility (2336-W Building) is located in the 200 West Area of the Hanford Site, south of 23rd Street and west of Dayton Avenue. Figure 1 illustrates the location of the Hanford Site and Figure 2 illustrates the location of WRAP.

The latitude and longitude are:

Latitude: $\quad 46^{\circ} 33^{\prime \prime} 31.9$

Longitude: $\quad 119^{\circ} 38^{\prime \prime} 21.4$

The address is:

U.S. Department of Energy, Richland Operations Office (DOE-RL)

Hanford Site

Richland, Washington 99352 


\subsection{RESPONSIBLE MANAGER}

Name, title, address, and phone number of the responsible manager.

George H. Sanders

Waste Management Division

U.S. Department of Energy, Richland Operations Office

P. O. Box 550

Richland, Washington 99352

(509) 372-1786

\subsection{PROPOSED ACTIONS}

Identify the type of proposed action for which this application is submitted.

a. Construction of new emission unit(s), or

b. Modification of existing emission unit(s); identify whether this is a significant modification.

The proposed action is considered an insignificant modification of the existing emission unit 296-W-4. The PTE in the original NOC (DOE/RL 93-15) was estimated to be $4.05+02$ millirem per year and the PTE in this NOC is estimated to be $1.13 \mathrm{E}+02$ millirem per year, resulting in a reduced PTE.

\subsection{STATE ENVIRONMENTAL POLICY ACT}

If this project is subject to the requirements of the State Environmental Policy Act (SEPA) contained in chapter 197-11 WAC, provide the name of the lead agency, lead agency contact person, and their phone number.

The proposed action categorically is exempt from the requirements of the SEPA under WAC 197-11-845.

\subsection{CHEMICAL AND PHYSICAL PROCESSES}

Describe the chemical and physical processes upstream of the emission unit(s).

The mission of the WRAP Facility includes examining, assaying, characterizing, treating, verifying, and repackaging solid radioactive material and mixed waste to enable treatment, storage, or disposal. The WRAP Facility manages many categories of radioactive materials such as low-level waste (LLW), transuranic (TRU) waste, TRU mixed waste, and low-level mixed waste (LLMW). The WRAP Facility normally only accepts contact-handled $(\mathrm{CH})$ containers. $\mathrm{CH}$ containers are a category where the external surface dose rate does not exceed 200 millirem per hour. Remote-handled (RH) containers are received on a case-by-case basis with additional administrative controls.

The physical, chemical, and radiological attributes of the newly generated waste are expected to be well known before receipt at the WRAP Facility, while retrieved drums could contain less than fully characterized waste. Whether newly generated or retrieved, the radioactive material might not have been sampled before coming to the WRAP Facility. In every case, however, sufficient knowledge of the radioactive material is obtained by sampling or process knowledge to ensure proper management of the radioactive material. 
The WRAP Facility consists of the following areas (Figure 3):

- Shipping and receiving area

- Nondestructive examination/nondestructive assay (NDE/NDA) area

- Processing area

- Ancillary support areas, including the heating, ventilation, and air conditioning (HVAC), electrical room, mechanical room, and administration areas.

A schematic showing the typical flow of incoming radioactive material through these areas is provided in Figure 4. Waste generated as a result of operations in the WRAP Facility (e.g., housekeeping, survey, and maintenance activity) is not subject to the flow schematic in Figure 4. These containers can be handled to add or remove waste at any location within the WRAP Facility, except for administrative areas.

\subsection{SHIPPING AND RECEIVING}

Containers are delivered to and transferred/shipped from the shipping and receiving area by truck or forklift. In the shipping and receiving area, incoming boxes and drums are unloaded, visually inspected, bar code labeled, and radiologically surveyed. Information pertaining to each container is entered into the data management system.

Following visual inspection, containers are transferred to the lag storage area. From the lag storage area, incoming drums are transferred to a weigh station and on to the NDE/NDA area for further characterization.

Once characterized, verified, and/or certified, the certified TRU waste is loaded into transuranic package transporter (TRUPACT-2) shipping casks for shipment to the Waste Isolation Pilot Plant (WIPP) in New Mexico. Verified LLW is transferred for disposal onsite. Mixed waste is moved to an offsite treatment or permitted storage facility or to an onsite treatment, disposal, and/or storage unit. Radioactive material that fails verification is returned to the generator, processed to correct the problem, or sent to another facility for further reprocessing.

\subsection{NONDESTRUCTIVE EXAMINATION/NONDESTRUCTIVE ASSAY SYSTEMS}

The NDE/NDA area is used to examine and to certify LLW, LLMW, TRU, and TRU mixed waste container contents without opening the containers.

The primary function of NDE is to examine the physical contents of containers entering and leaving the WRAP Facility to determine whether there are any noncompliant items or unacceptable conditions in the containers. This examination of the containers is accomplished by the use of the real-time radiography (RTR) system. The RTR system consists of an x-ray imaging system used to identify noncompliant items, such as free or containerized liquids, compressed gas containers including aerosol cans, and other suspected dangerous waste/materials. Data from the $\mathrm{x}$-ray examination are entered into the data management system for each container.

The primary function of NDA is to determine the activity levels of radionuclides in the radioactive material entering and leaving the WRAP Facility. This information is used to categorize the radioactive 
material, provide inventory control information, determine appropriate handling of individual containers, and to determine if the material meets applicable transportation and disposal criteria. The NDA equipment includes passive-active neutron assay systems and/or gamma energy analysis systems. Data from the analysis of each container are entered into the data management system.

\subsection{PROCESS AREA}

The process area consists of four glovebox lines: a TRU waste process glovebox, a TRU waste restricted waste management (RWM) glovebox, a LLW process glovebox, and a LLW RWM glovebox.

Schematics showing the typical flow of material through the TRU and LLW waste lines are shown in Figure 5 and Figure 6, respectively. In the process gloveboxes, drums are opened, the contents sorted and sampled, if necessary, noncompliant items removed and transferred to the RWM gloveboxes, and the remaining compliant waste repackaged into new drums.

The airborne radiological contaminants produced at the WRAP Facility are expected to be generated in these gloveboxes. Incoming drums generally are opened in gloveboxes. However, it might be necessary to loosen a lid or replace a damaged lid outside of a glovebox.

\subsubsection{Transuranic Waste Process Line}

The TRU waste process glovebox line consists of stainless steel modular gloveboxes that are bolted together in a linear configuration. Windows are gasketed and bolted to the glovebox wall, and gloveports are fitted to the glovebox wall and windows to accept push-through type gloves. Glovebox ventilation is of the once-through type. Air is drawn from the process room, through a nontestable high-efficiency process filter, and into the glovebox. The air is exhausted from the glovebox through another nontestable high-efficiency process filter to the combined glovebox exhaust system.

Process operations are performed inside of the gloveboxes by using the gloves and/or remote controlled manipulators. Drums are loaded into the glovebox through airlock and sealed-type entry systems. Noncompliant items are labeled and transferred to the TRU RWM glovebox using a reusable transfer system. Compliant waste is repackaged into new drums

\subsubsection{Transuranic Waste Restricted Waste Management Line}

The TRU waste RWM glovebox line consists of stainless steel. Window, gloveport, ventilation, and manipulator features are similar to those described for the TRU waste process line glovebox. Glovebox ventilation is of the once-through type. Air is drawn from the process room, through a nontestable high-efficiency process filter, and into the glovebox. The air is exhausted from the glovebox through another nontestable high-efficiency process filter to the combined glovebox exhaust system. Noncompliant waste is received from the TRU waste process line in a reusable transfer container.

The treatment and repackaging operations that occur in the TRU waste RWM glovebox could include the following.

- Aerosol cans are depressurized and drained. The drained liquids are treated within the gloveboxes in accordance with the WRAP Facility RCRA permit application (DOE/RL-91-16) or retained in containers, which are sent to storage outside of the WRAP Facility. Vapors from the aerosol cans are passed through a series of demisters for removal of entrained liquids, and vented to the glovebox exhaust. 
- Miscellaneous inorganic liquids are sampled for characterization, neutralized if required, and solidified using stabilizing additives.

- Miscellaneous organic liquids are sampled for characterization, treated within the gloveboxes in accordance with the WRAP Facility RCRA permit application, or repackaged for transfer to storage facilities pending future treatment.

- Corrosive materials are neutralized. After neutralization, the materials are solidified or loaded out for storage or treatment outside the WRAP Facility.

- Other RCRA permitted treatment such as mercury amalgamation, stabilization of heavy metals, and macroencapsulation could be performed.

- Radioactive material is repackaged to meet acceptance criteria of the receiving facility.

- Radioactive material is sampled.

The empty aerosol cans and other treated LLW packages can be loaded into new drums and routed to the LLW process glovebox for compaction or loaded out of the RWM glovebox for storage, disposal, or additional treatment.

\subsubsection{Low-Level Waste Process Line}

The LLW process glovebox line consists of stainless steel modular gloveboxes that are bolted together in a linear configuration. Glovebox ventilation is of the once-through type. Air is drawn from the process room, through a nontestable high-efficiency process filter, and into the glovebox. The air is exhausted from the glovebox through another nontestable high-efficiency process filter to the combined glovebox exhaust system.

Drums enter the glovebox through an airlock entry system. Noncompliant items are bar code labeled and transferred to the LLW RWM glovebox using a reusable transfer system. Compliant waste is compacted and repackaged into new drums.

\subsubsection{Low-Level Waste Restricted Waste Management Process Line}

The operations in the LLW RWM process line are identical to the operations in the TRU waste RWM line (Section 5.3.2).

\subsection{SOURCES AND CONTROLS}

Describe the existing and proposed (as applicable) abatement technology. Describe the basis for the use of the proposed system. Include expected efficiency of each control device, and the annual average volumetric flow rate(s) in meters $3 / \mathrm{sec}$ for the emission unit(s).

Ventilation exhaust points at the WRAP Facility are divided into three general categories: the exhaust stack, fugitive emissions, and miscellaneous vents. The stack emissions sources are described in Section 6.1.1. Fugitive emissions sources are described in Section 6.1.2. Miscellaneous vents sources are discussed in Section 6.1.3 
Figure 7 depicts the WRAP Facility stack, which is the single discharge point (i.e., source). The source registration for radioactive air emissions for the WRAP Facility, registered with Washington State Department of Health (WDOH), shows the 2336-W Building and the discharge point as the WRAP Facility exhaust stack. Figure 8 depicts a simplified schematic of the Zone $I$ and Zone II ventilation system.

\subsection{DESCRIPTION OF THE SOURCES}

Areas where containers could be opened are considered potentially contaminated. These areas are designated as ventilation zones. Ventilation Zone I includes the areas of highest potential contamination (i.e., gloveboxes and exhaust ducts from gloveboxes). Ventilation Zone II includes areas with lower potential for contamination (i.e., rooms in which Zone I areas are located, other areas with some potential for contamination, and exhaust ducts from Zone II areas). The HVAC system maintains airflow from noncontaminated areas to areas of progressively higher potential contamination by controlling the air pressure in the ventilation zones. Zone II areas are maintained at lower pressure than atmospheric pressure; Zone I areas are maintained at a lower pressure with respect to Zone II.

Also, some areas within a specific ventilation zone are kept at different pressures with respect to each other to maintain desirable airflow patterns. For example, the air pressure in the process room is maintained at a lower air pressure than the process HVAC equipment room. Although both rooms are ventilation Zone II, this difference in air pressure maintains the airflow from the process HVAC equipment room to the process room.

Areas where containers are handled only in a closed condition are the shipping and receiving areas and the NDE/NDA areas. These areas are considered 'uncontrolled' because the air pressure in these areas specifically is not controlled with respect to either atmospheric pressure or other areas of the WRAP Facility. Exhaust air from these areas is not filtered. Two-thirds of the containers in these areas could be vented through either a NucFil ${ }^{\oplus}$ filter, vent clip, or similar system.

\subsubsection{Exhaust Stack}

All of the ventilation air from Zone I and Zone II is exhausted through the exhaust stack. This stack is approximately 14 meters high and is located approximately 3 meters to the west of the northwest corner of the WRAP Facility. The exhaust stack is the emission point for ventilation Zone I and ventilation Zone II. A simplified schematic of the Zone I and Zone II ventilation system is provided in Figure 8.

Approximately 7.72 cubic meters per second of air are discharged through the exhaust stack at a temperature of about $32.2^{\circ} \mathrm{Centigrade}$.

\subsubsection{Zone I Area}

The Zone I gloveboxes and the glovebox exhaust system contribute the majority of the radioactive air pollutants present in the emissions from the WRAP Facility.

The gloveboxes receive makeup air from the Zone II area. Air flows from the room into the gloveboxes through push-through filters by virtue of the pressure differential between the gloveboxes and the room. Each of these push-through filters has a rated capacity of 0.02 cubic meter per second. Each glovebox is

\footnotetext{
${ }^{\oplus}$ Nucfil $^{\oplus}$ is a registered trademark of Nuclear Filter Technology, Inc.
} 
1 provided with the appropriate quantity of push-through filters to prevent the inadvertent migration of 2 contamination from the gloveboxes back into the room through the air inlets.

Air from the gloveboxes flows through nontestable process filters to the Zone I exhaust filters. After treatment in the Zone I exhaust filters, approximately 0.43 cubic meter per second of filtered exhaust air is combined with the filtered air from the Zone II exhaust system for discharge through the stack.

\subsubsection{Zone II Areas}

Zone II areas include the process room, the process HVAC equipment room, the decontamination room, and the warm maintenance room. Make-up air to Zone II areas includes filtered outside air supplied by fans, planned air in-leakage, and airlocks.

A total of approximately 7.29 cubic meters per second of air is exhausted by the Zone Il exhaust system. The 7.29 cubic meters per second of air are exhausted using a ventilation control and air treatment system, which is separate from that used for the Zone I areas. After treatment, the Zone II exhaust is combined with treated exhaust from the Zone I areas and discharged through the exhaust stack.

\subsubsection{Fugitive Emissions}

Fugitive emissions are expected to occur from the shipping/receiving and NDE/NDA areas from the vented containers. The shipping/receiving area can store up to 216 containers at any one time.

Additional containers could be stored on the floor. It is estimated that approximately two-thirds of the containers will be vented. However, at any one time, either none of the containers in the shipping/receiving area or all of the containers could be vented.

During normal HVAC system operation in the NDE/NDA area, air is recirculated, with air exhausted by leakage through doorways and miscellaneous points.

\subsubsection{Miscellaneous Vents}

None of the vents described in this section are expected to contain radioactive air pollutants. The vents are described only to provide a complete description for the WRAP Facility.

During normal operation, air is exhausted through wall louver RV-11-402 from the material preparation room, which is part of the administrative and office areas. In economizer mode, additional air is exhausted through wall louver LV-11-401. Emissions from the locker/change rooms and administrative areas are not anticipated to contain radioactive air pollutants, as radioactive material is not handled in these areas.

\subsection{DESCRIPTION OF THE CONTROLS}

The stack emissions control system, control devices, and fugitive emissions controls are discussed in the following sections. 


\subsubsection{Description of Effluent System}

Because the radioactive airborne emissions consist primarily of particulate matter generated during the processing of radioactive solid material, the emissions control system is capable of containing micrometer- and submicrometer-sized particles.

Zone I and Zone II exhausts are each ducted to their own high-efficiency particulate air (HEPA) filtration banks, each bank consisting of two stages of HEPA filters, with one serving as backup to the other. During routine maintenance activities (e.g., filter changeout) or if an equipment component fails, the exhaust flow is diverted to the backup filter bank. The exhausts are combined and subsequently discharged to the atmosphere.

The Zone I and II exhaust fans have a maximum combined flow of 570 cubic meters per minute. The exhaust fan flow control dampers are adjusted automatically, as necessary, to control the final HEPA filter inlet header pressure. The supply fan outlet header pressure is controlled in a similar manner by adjusting the supply fan control dampers. The header pressure setpoints were determined during initial design, and were confirmed during air balance testing before startup as those necessary to maintain the internal flows and zone pressures.

The WRAP gloveboxes are equipped with nontestable high-efficiency process filters on both the inlet and outlet flows to minimize the radionuclide contamination of the exhaust ducts and final filter banks. If necessary, these filters can be by-passed.

The best available radionuclide control technology (BARCT) assessment developed for this proposed project demonstrates that the prefilter and HEPA system provides the highest degree of removal efficiency (WHC-SD-W026-TI-004).

\subsubsection{Efficiency Values of The Control Devices for Removal of Radioactivity}

HEPA filters are the control devices used for removal of radioactive particles from the Zone I and Zone II ventilation systems. Hanford Site HEPA filters meet the following requirements:

- Permissible penetration at test airflows are no greater than 0.03 percent when tested in accordance with Nuclear Standard Quality Assurance Testing of HEPA filters (NE F 3-43, Article 6)

- Filters have a minimum particle collection efficiency of 99.97 percent for 0.3 -aerodynamic equivalent diameter particle size aerosol at 100 percent and at 20 percent of rated flow capacity for filters with a nominal airflow rating of 0.06 cubic meter per second (size 3 ), and larger, and 100 percent rated flow for filters with a nominal rating below 0.06 cubic meter per second (NE F 3-43, Article 4). The challenge aerosol currently used is Emery 3004, a synthetic aliphatic hydrocarbon, polyalphaolefin.

- The pressure differential for air flow across a clean filter assembly when tested at appropriate nominal flows will not exceed 1.3 inch water column (WC) for size 3 HEPAs and smaller, and 1.0 inch WC for HEPAs larger than size 3. 


\subsection{Fugitive Emissions}

Vented containers are sources of fugitive emissions. All TRU waste containers and some LLW containers are equipped with passive vents, either vent clips, NucFil ${ }^{\circledR}$ filters, or similar type devices. All vent clips will be replaced with NucFil ${ }^{\star}$ filters or similar type devices as the drums are prepared for shipment to either WIPP or transferred to other locations onsite. All incoming containers are maintained in closed condition within the WRAP Facility, and only are opened inside of Zone I, Zone II, or other enclosures providing equivalent or superior containment.

\subsection{DRAWINGS OF CONTROLS}

Provide conceptual drawings showing all applicable control technology components from the point of entry of radionuclides into the vapor space to release to the environment.

A brief description of applicable drawings are as follows:

Figure 7. Waste Receiving and Processing Facility Stack. This sketch shows the locations and dimensions of the stack, samplers, and access points.

Figure 8. Schematic of Zone I and Zone II Ventilation System. This sketch shows the conceptual layout of Zone I and Zone II, and the HEPA filter banks in relation to the stack.

\subsection{RADIONUCLIDES OF CONCERN}

Identify each radionuclide that could contribute greater than ten percent of the potential-to-emit TEDE to the MEI, or greater than $0.1 \mathrm{mrem} / \mathrm{yr}$ potential-to-emit TEDE to the MEI.

The radionuclides of concern exist as particulates. All radionuclides are assumed to be either americium- 241 or strontium-90. This assumption provides a conservative estimate of the PTE from either the stack or vented containers. Radionuclides expected to be encountered are strontium-90, cesium-134, cesium-137, europium-152, europium-154, plutonium-238, plutonium-239, plutonium-240, plutonium241 , americium-241, americium-243, curium-244, and californium-252. In addition, essentially any radionuclide isotope could be encountered.

\subsection{MONITORING}

Describe the effluent monitoring system for the proposed control system. Describe each piece of monitoring equipment and its monitoring capability, including detection limits, for each radionuclide that could contribute greater than ten percent of the potential-to-emit TEDE to the MEI, or greater than 0.1 mrem/yr potential-to-emit TEDE to the MEI, or greater than twenty-five percent of the TEDE to the MEI, after controls. Describe the method for monitoring or calculating those radionuclide emissions. Describe the method with detail sufficient to demonstrate compliance with the applicable requirements.

The WRAP Facility stack is a major stack (296-W-4), therefore, the monitoring and sampling systems (Figure 9) were designed in accordance with the guidance provided in U.S. Department of Energy Order 6430.1A, Section 1589-99.0.1, ANSI N13.1-1969, and 40 CFR 61, Subpart H.

${ }^{\circledR}$ Nucfil $^{\circledR}$ is a registered trademark of Nuclear Filter Technology, Inc. 
1 The stack exhaust is monitored with an isokinetic stack emission monitoring system (ISEMS). The

2 ISEMS is a self-contained, microprocessor-based, radiation detection system used to monitor for airborne radioactive particulates. The WRAP Facility analyzers are capable of monitoring beta-emitting and alpha-emitting particulates. The other components of the sampling/monitoring system are described in the following sections.

\subsection{STACK FLOW MEASURING SYSTEM}

The WRAP Facility stack flow rate of 464 cubic meters per minute is measured by summing the flow through the operating exhaust fans. The exhaust fan flows are measured by flow meters on each fan outlet and data are displayed in the control room

\subsubsection{Sample Probes}

The stack sample isokinetic probe is a single probe assembly mounted by direct insertion into the stack monitoring flange perpendicular to the stack airflow. The probe assembly is made up of a multi-point velocity probe and a multi-point isokinetic nozzle rake for particulate collection. Each nozzle orifice is tapered ( $<30$ foot taper on the outside edge of the orifice) and faces directly into the exhaust stream. Each independent multi-point nozzle array has thread-on sampling nozzles placed at the centroid of each equal area within the stack. The number and placement of the nozzles are consistent with ANSI N13.1.

\subsubsection{Number and Location of Sampling Points}

There are three stack sampling points, one for alpha sampling, one for beta sampling, and one for the filter paper (Figure 9). The sampling points are positioned permanently and designed and operated in accordance with 40 CFR 61.93 .

The sample point is located at least 5-stack diameters downstream from any flow perturbation (such as a duct connection). In addition, the probe is at least 2-stack diameters upstream of any flow disturbance (the top of stack). All are in accordance with 40 CFR 61.07.

\subsubsection{Description of Sample Lines}

The following characteristics of sample transport line/tubes were incorporated into the WRAP Facility design to ensure accurate and reliable sampling.

- The design of sample transport tubing ensures that the lines are as short as possible. Lines have no sharp bends, and any changes in direction have been made with radii curvatures greater than 5-tube diameters.

- Tubing size was selected to minimize particle deposition due to gravitational settling and/or impaction.

- The sampling transport tubing is constructed of seamless stainless steel, is rigid, and adequately is supported to prevent sagging.

- Use of pipe or tube fittings between the sample probes and the sample collectors is minimized. 
- Sample tubing is grounded electrically to the point where the particles are collected.

- The heat tracing of the sample transport tubing is insulated thermally to reduce heat loss to the atmosphere.

- Easily accessible calibration taps are included in the sample line to allow in-place verification of the sample line flowrate. A block valve is included in the sample delivery lines upstream and downstream of the electronic cabinet to isolate the cabinet from the stack effluent for maintenance. Block valves also are located upstream and downstream of the sample delivery pumps for isolation.

\subsubsection{Sample Flow Regulation.}

The stack monitor flow is drawn from the stack to the analyzer with a regulated air pump. The sample flowrate is controlled to maintain an isokinetic sample. The sample flowrate is controlled with an adjustment on the pump and monitored with a differential pressure connected across a flow orifice.

\subsubsection{Sampling Media.}

Millipore ${ }^{\circ}$ membrane filters are used as the sampling medium. Because the filters are not very stiff, the filters are supported on metal gauze or other grid. The filters are 47 -millimeter Versapor $3000^{\oplus}$ or equivalent air sample filters capable of collecting 0.3 -micrometer size particles with a collection efficiency of 95.8 percent.

\subsubsection{Frequency of Sampling (Continuous or Batch)}

The stack monitoring system provides for both continuous and batch sampling. The airborne effluent is sampled continuously. Samples are collected biweekly at a minimum.

\subsection{CALIBRATION SCHEDULES}

Airborne emission sampling equipment is calibrated annually at a minimum. Minimum detection limits are achieved in accordance with the current version of HNF-EP-0835. Stack sampling rotameters and pressure gauges are calibrated annually according to ANSI Z540-1994 calibration by usage methodology.

\subsection{ANNUAL POSSESSION QUANTITY}

Indicate the annual possession quantity for each radionuclide.

The WRAP Facility can handle any radionuclide listed in the periodic table at any time. It is estimated that the total amount of radionuclides in any one container will not exceed 20 curies (DOE/RL-93-15). It further is estimated that the alpha emitters would make up approximately 1.25 curies and the beta/gamma emitters would make up approximately 18.75 curies on average in any container.

\footnotetext{
- Millipore is a registered trademark of Millipore Corporation, Bedford, MA.

${ }^{2}$ Versapor 3000 is a registered trademark of the Pall (Gelman) Corporation, Ann Arbor, MI.
} 
The shipping/receiving area and the NDE/NDA area can receive approximately 20,475 containers annually, of which approximately 13,650 containers will be vented (operating three shifts per day, 7 days per week, and 52 weeks per year). Using americium-241 to represent the alpha emitters and strongium-90 to represent the beta/gamma emitters, the total annual possession quantity (APQ) would be 17,062 curies for alpha emitters and 255,938 curies for beta/gamma emitters.

The process area can process approximately 8,000 containers annually (operating three shifts per day, 7 days per week, and 52 weeks per year). Again, using americium-241 to represent the alpha emitters and strongium-90 to represent the beta/gamma emitters, the total APQ would be 10,000 curies for alpha emitters and 150,000 curies for the beta/gamma emitters.

\subsection{PHYSICAL FORM}

Indicate the physical form of each radionuclide in inventory: Solid, particulate solids, liquid, or gas.

All the radionuclides listed in Section 10.0 are present as particulate solids at ambient conditions.

\subsection{RELEASE FORM}

Indicate the release form of each radionuclide in inventory: Particulate solids, vapor, or gas. Give the chemical form and ICRP 30 solubility class, if known.

All the radionuclides listed in Section 10.0 are released as particulate solids.

\subsection{RELEASE RATES}

Release Rates:

a. New emission unit(s): Give predicted release rates without any emission control equipment (the potential-to-emit) and with the proposed control equipment using the efficiencies described in subsection (6) of this section, or

b. Modified emission units(s): Give predicted release rates without any emissions control equipment (the potential-to-emit) and with the existing and proposed control equipment using the efficiencies described in subsection (6) of this section. Provide the latest year's emissions data or emissions estimates.

The original NOC estimated the average curies per container at approximately 20 curies (DOE/RL-93-15). This estimate is used to calculate the PTE for the beta/gamma emitters (using strongtium-90 for a worst-case scenario) and alpha emitters (using americium-241 for a worse-case scenario).

Unabated emissions from the process area are calculated by multiplying the APQ by the 40 CFR 61 , Appendix D, release factor for particulates (1.00 E-03). Unabated fugitive emissions are calculated by multiplying the release factor agreed to by WDOH in their correspondence dated October 18, 1999 (AIR 99-1006).

Abated emissions are calculated by applying a decontamination factor for one HEPA filter to the unabated emissions. The decontamination factor for one HEPA filter is equal to:

$1 /(1$-efficiency $)=1 /(1-0.9995)=2 E+03$. 
The abated emissions equal the unabated emissions divided by the overall decontamination factor.

Table 1 contains the average curies per container of both the beta/gamma and alpha emitters and the calculated release rates for both the fugitive and stack emissions and the abated release rates for the stack emissions.

\subsection{LOCATION OF MAXIMALLY EXPOSED INDIVIDUAL}

Identify the MEI by distance and direction from the emission unit(s). The MEI is determined by considering distance, windrose data, presence of vegetable gardens, and meat or milk producing animals at unrestricted areas surrounding the emission unit.

Using the 5-year meteorological data and past studies of 200 West Area airborne releases (Attachment 1), the location of the MEI was determined at 24 kilometers east of the WRAP Facility (Laser Interferometer Gravitational Wave Observatory Facility).

The unit dose factors resulting from the dispersion modeling are in Attachment 1 in units of millirem per curie. These conversion factors are multiplied by the estimated controlled emissions rates expected from the WRAP Facility. The results are presented in Table 1. Some of the parameters used in the modeling are as follows:

Source terms: Projected annual releases from the WRAP Facility

Release height: Height the emissions release was taken (i.e., zero or ground level)

Inhalation rate: An individual was assumed to breathe 8,500 cubic meters per year

MEI: $\quad$ Doses were estimated for an individual living 24 kilometers east of the WRAP Facility.

Meteorology: Hanford Site Meteorological Station data and onsite meteorological data were used (Attachment 1).

\subsection{TOTAL EFFECTIVE DOSE EQUIVALENT TO THE MAXIMALLY EXPOSED INDIVIDUAL}

Calculate the TEDE to the MEI using an approved procedure (see WAC 246-247-085). For each radionuclide identified in subsection(8) of this section, determine the TEDE to the MEI for existing and proposed emission controls, and without emission controls (the potential-to-emit) using the release rates from subsection (13) of this section. Provide all input data used in the calculations.

Table 1 contains the calculations for the unabated TEDE to the MEI and the abated TEDE to the MEI for the stack emissions. The calculations for the fugitive emissions are for the unabated TEDE to the MEI only.

\subsection{COST FACTOR IF NO ANALYSIS}

Provide cost factors for construction, operation, and maintenance of the proposed control technology components and system, if a BARCT or ALARACT demonstration is not submitted with the NOC.

Cost factors for construction, operation, and maintenance of proposed technology requirements are not provided, as the BARCT demonstration already has been submitted (WHC-SD-W026-TI-004). 
WDOH has provided guidance that HEPA filters generally are BARCT for particulate emissions (AIR 92-107). Because the radionuclides of concern are particulates, it is proposed that the control devices described in Section 6.0 for the 296-W-4 Stack be accepted as BARCT.

\subsection{DURATION OR LIFETIME}

Provide an estimate of the lifetime for the facility process with the emission rates provided in this application.

Activities covered by this NOC will take place through 2027 .

\subsection{STANDARDS}

Indicate which of the following control technology standards have been considered and will be complied with in the design and operation of the emission unit(s) described in this application:

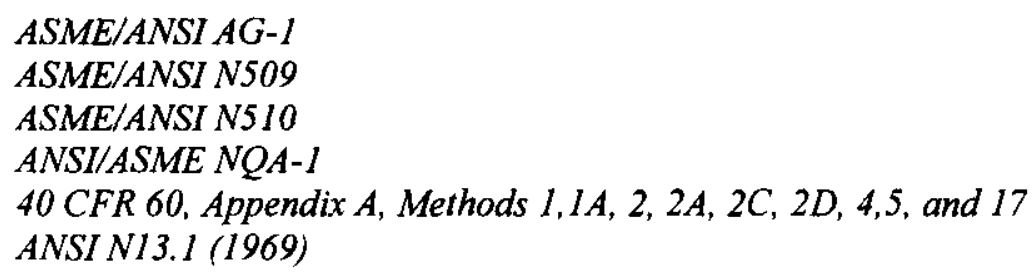

Cited documents will be provided to WDOH on request.

- ASME/ANSI AG-1:

The HEPA filters used in the 296-W-4 Stack ventilation system meet all but two criteria dealing with filter qualification testing. Justification for this exception was discussed with and approved by WDOH at the December 1998 Routine Technical Assistance Meeting. A WDOH approved temporary deviation is currently in place (AIR 99-507).

- ASME/ANSI N509:

Compliance with the ASME/ANSI N509 standards is documented in the U.S. Environmental Protection Agency (EPA) Level II Inspection Report and the follow-up meeting minutes dated February 12, 1998 (DOE/RL-EAP).

- ASME/ANSI N510:

Compliance with the ASME/ANSI N510 standards is documented in the EPA Level II Inspection Report and follow-up meeting minutes dated February 12, 1998 (DOE/RL-EAP).

- ANSI/ASME NQA-1:

Quality assurance is addressed in HNF-0528-3, NESHAP Quality Assurance Project Plan for Radioactive Airborne Emissions (all of Sections 2.0, 3.0 and 5.0) as a compatible alternative to NQA-1. 
- ANSI/ASME NQA-2:

The standard is no longer an active National Standard and has been incorporated into NQA-1.

Compliance compatible with NQA-1 was described previously.

- 40 CFR 60, Appendix A

Stack flow will be tested using Methods 1 and 2. Methods 1 A, 2A, 2C and 2D are not applicable to the stack dimensions/design. Methods 4, 5, and 17 are not applicable to radioactive airborne effluent stacks.

\section{- ANSI N13.1}

The 296-W-4 Stack currently meets ANSI N13.1-1969 criteria and is listed in the Federal Facility Compliance Agreement as fully compliant (ANSI N13.1).

\subsection{REFERENCES}

AIR 92-107, WDOH to DOE-RL, "Surveillance Report Generated by the DOH of KE \& KW Basin on 09/16/1992", October 05, 1992.

AIR 99-507, WDOH to DOE-RL, "Technical Justification for Temporary Deviation to American Society of Mechanical Engineers (ASME) AG-1, Section FC 5100 High Efficiency Particulate Air (HEPA) Filter Qualification Test Requirements", May 19, 1999.

AIR 99-1006, WDOH to DOE-RL, "Request for Approval Vented Container Annual Release Fraction", October 18, 1999.

ANSI N13.1, Guide to Sampling Airborne Radioactive Materials in a Nuclear Facility, 1969, American National Standards Institute, New York, New York.

ANSI/ASME NQA-1, Quality Assurance Requirements for Nuclear Facility Applications, 1994, American National Standards Institute and American Society of Mechanical Engineers, New York, New York.

ASME/ANSI AG-1, Code on Nuclear Air and Gas Treatment, 1991, American Society of Mechanical Engineers and American National Standards Institute, New York, New York.

ASME/ANSI-N509, Nuclear Power Plant Air-Cleaning Units and Components, 1989, American Society of Mechanical Engineers and American National Standards Institute, New York, New York.

ASME/ANSI-N510, Testing of Nuclear Air Treatment Systems, 1989, American Society of Mechanical Engineers and American National Standards Institute, New York, New York.

Beres, D. A., 1990, The Clean Air Act Assessment Package-1988 (CAP-88), A Dose and Risk Assessment Methodology for Radionuclide Emissions to Air. Vols. 1-3, U.S. Environmental Protection Agency.

Carter, G., 1993, HEPA Filters in Series and Projected Efficiency, (telephone conversation with M. Cutler, testing manager, Flanders Filters, March 8), EBASCO, Richland, Washington.

DOE Order 6430.1A, General Design Criteria, U.S. Department of Energy, Washington, D.C. 
DOE-RL, 1992, Response to State of Washington Department of Health Technical Review of Hanford Site Permit FF-0I Supplemental Information, 1992, U.S. Department of Energy, Richland Field Office, Richland, Washington.

DOE/RL-90-34, State of Washington Department of Health, Radioactive Air Emissions Permit FF-01: Supplemental Information, U.S. Department of Energy, Richland Field Office, Richland, Washington.

DOE/RL-91-16, Hanford Facility Dangerous Waste Permit Application, Waste Receiving and Processing Facility, U.S. Department of Energy, Richland Operations Office, Richland, Washington.

DOE/RL-93-15, Application for Approval to Construct the Waste Receiving and Processing Facility, 1993, U.S. Department of Energy, Richland Operations Office, Richland, Washington.

DOE/RL-93-16, Application for Approval to Construct the Waste Receiving and Processing Facility, U.S. Department of Energy, Richland Operations Office, Richland, Washington.

DOE/RL-99-60, Request for Approval-Vented Container Annual Release Fraction, U.S. Department of Energy, Richland Operations Office, Richland, Washington.

DOE/RL-EAP, "EPA Level II Inspection Closeout for WRAP Facility", Meeting Minutes, February 12, 1988.

EPA, 1993, Letter: J. McCormick, EPA to J. D. Bauer, DOE-RL, May 10, 1993, "Approval to construct Waste Receiving and Processing Facility".

HNF-0528-3, NESHAP Quality Assurance Project Plan for Radioactive Air Emissions, September 1998, Fluor Hanford, Richland, Washington.

HNF-EP-0835-6, Rev. 0, Statement of Work for Services Provided by the Waste Sampling and Characterization Facility for the Environmental Compliance Program, Fluor Hanford, Richland, Washington, June 2000.

NE F 3-43, 1990, Quality Assurance Testing of HEPA Filters, U.S. Department of Energy, Washington, D.C.

PNL-4622, Climatological Summary for the Hanford Area, Pacific Northwest Laboratory, Richland, Washington.

PNL-7930, Hanford Site Environmental Report for Calendar Year 1990, Pacific Northwest Laboratory, Richland, Washington.

WDOH, 1989, State of Washington Department of Health Radioactive Air Emissions Permit Number FF-01, 1989, State of Washington Department of Health, Olympia, Washington.

WHC-SD-WO26-TI-003, WRAP Module I Air Emissions Source Term for Air Emissions, Westinghouse Hanford Company, Richland, Washington.

WHC-SD-WO26-TI-004, 1992, WRAP Module I Best Available Radionuclide Control Technology Assessment, Westinghouse Hanford Company, Richland, Washington. 


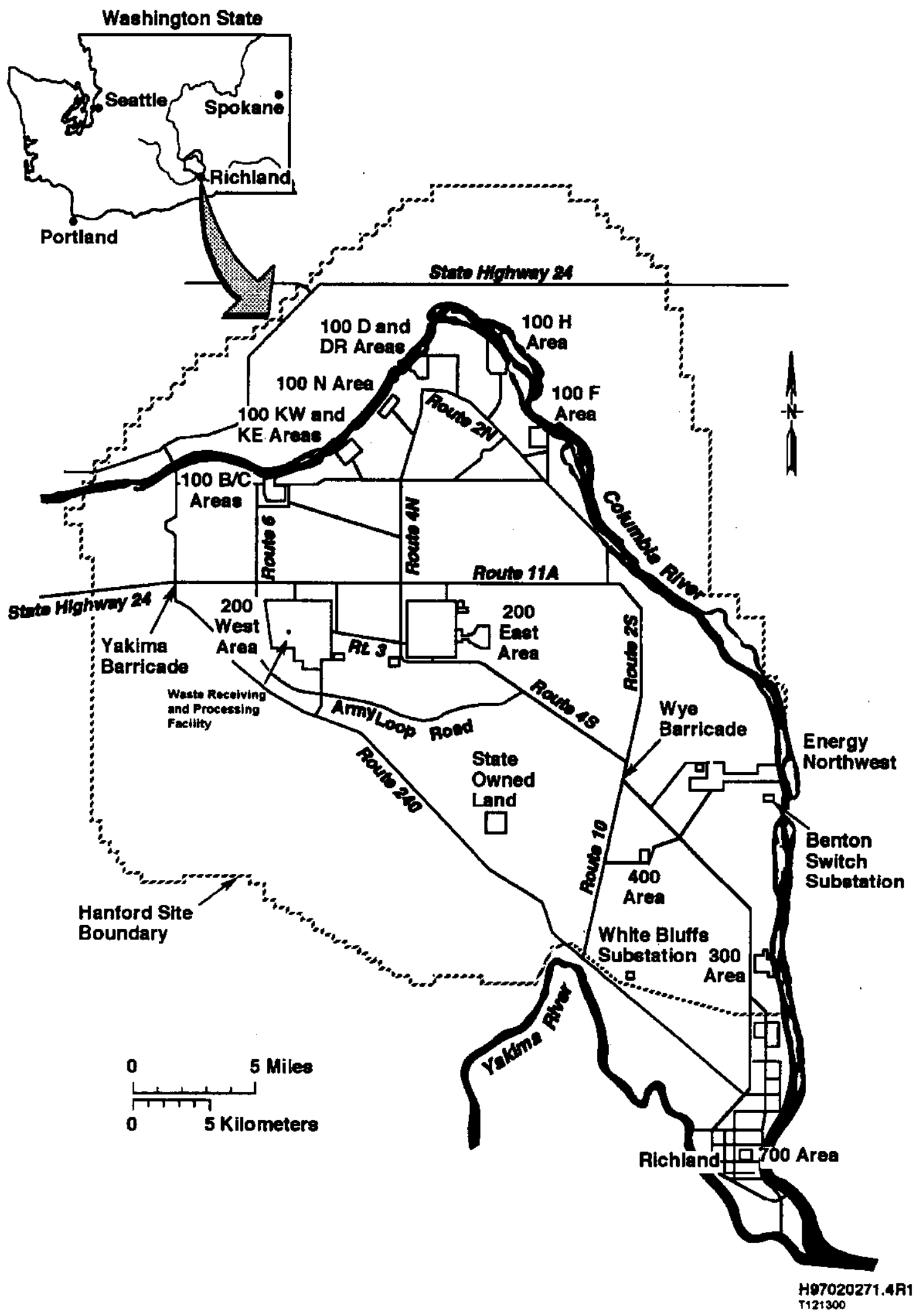

Figure 1. Hanford Site. 


\section{Waste Receiving and Processing Facility (WRAP)}

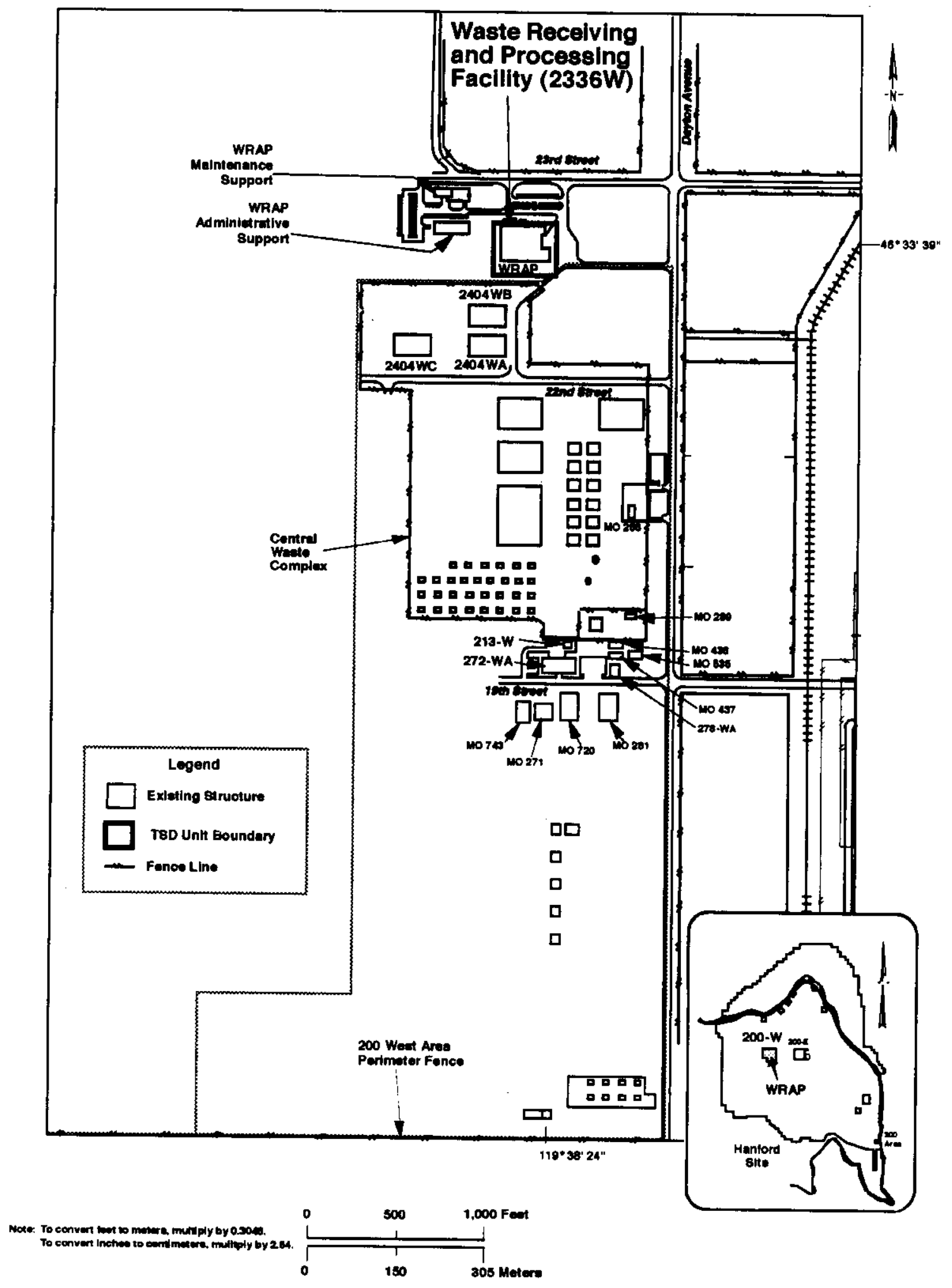

Hos030043.3R2

Figure 2. Location of the Waste Receiving and Processing Facility in the 200 West Area. 


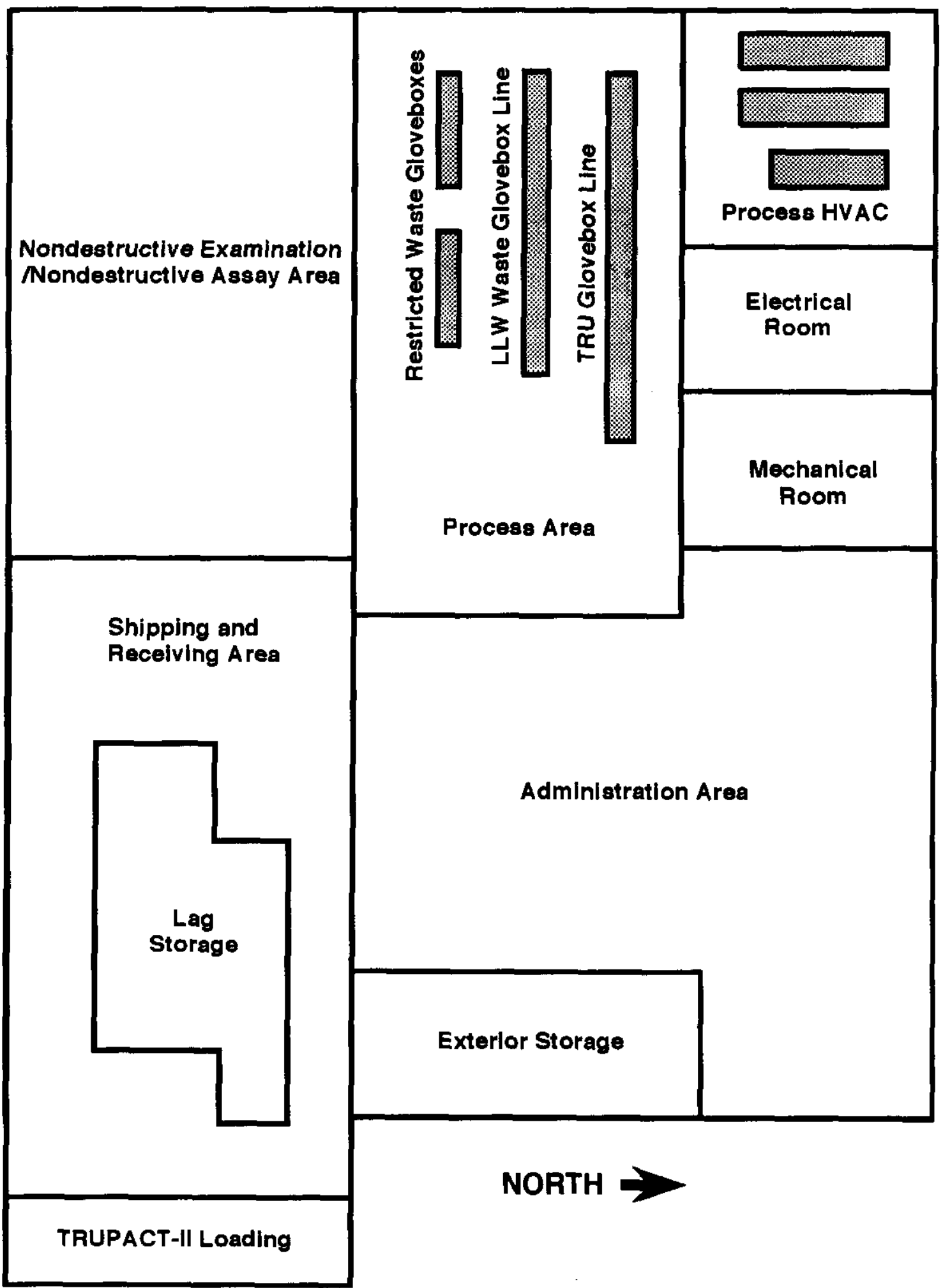

HVAC = heating, ventilation, and air condltioning

LLW = low-level waste

TRU = transuranic (waste)

Note: Upper floor plan contalning the control room ls not shown

TRUPACT = transuranle waste transporter

Figure 3. Waste Receiving and Processing Facility Floor Plan. 


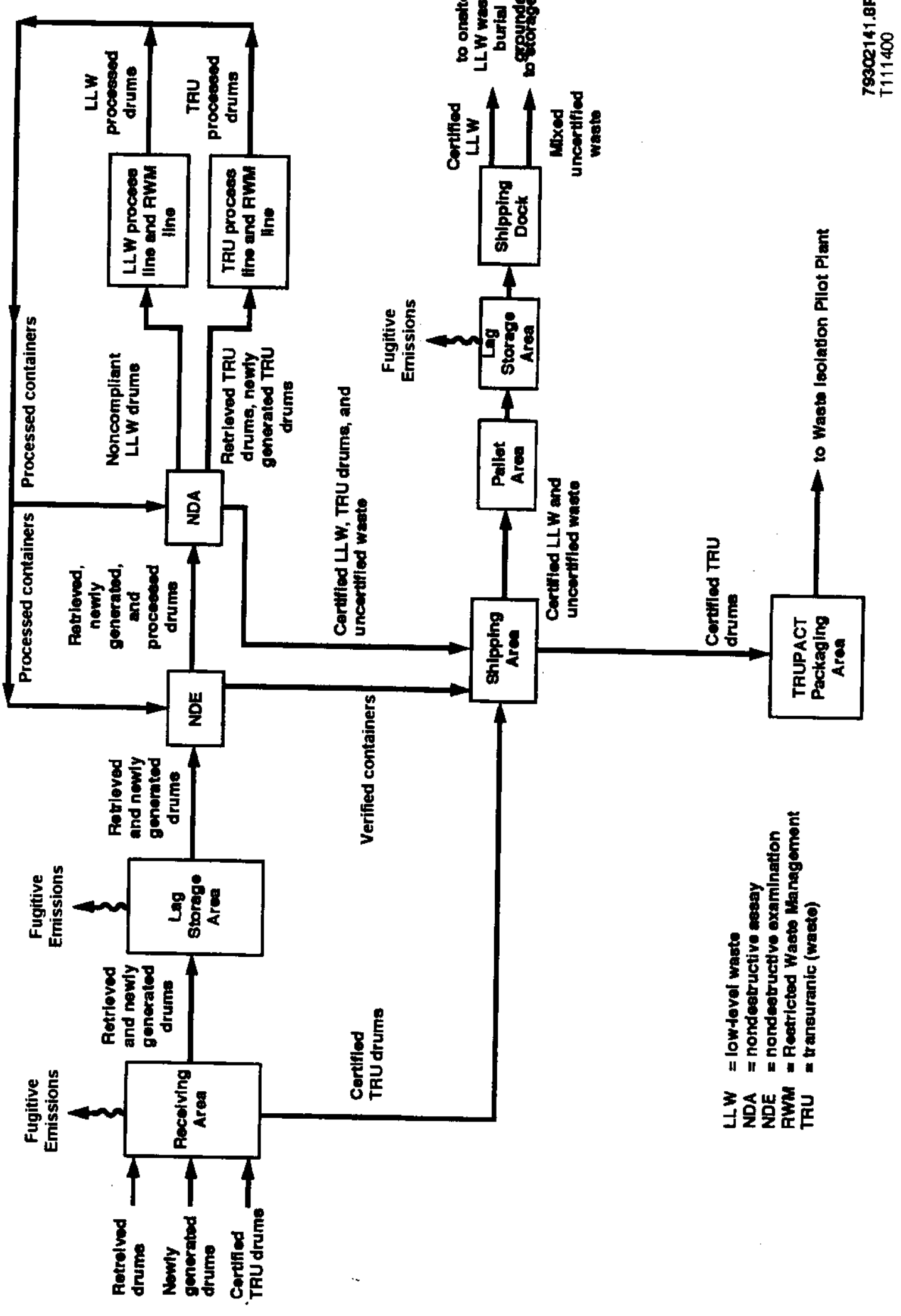

Figure 4. Waste Flow Diagram. 


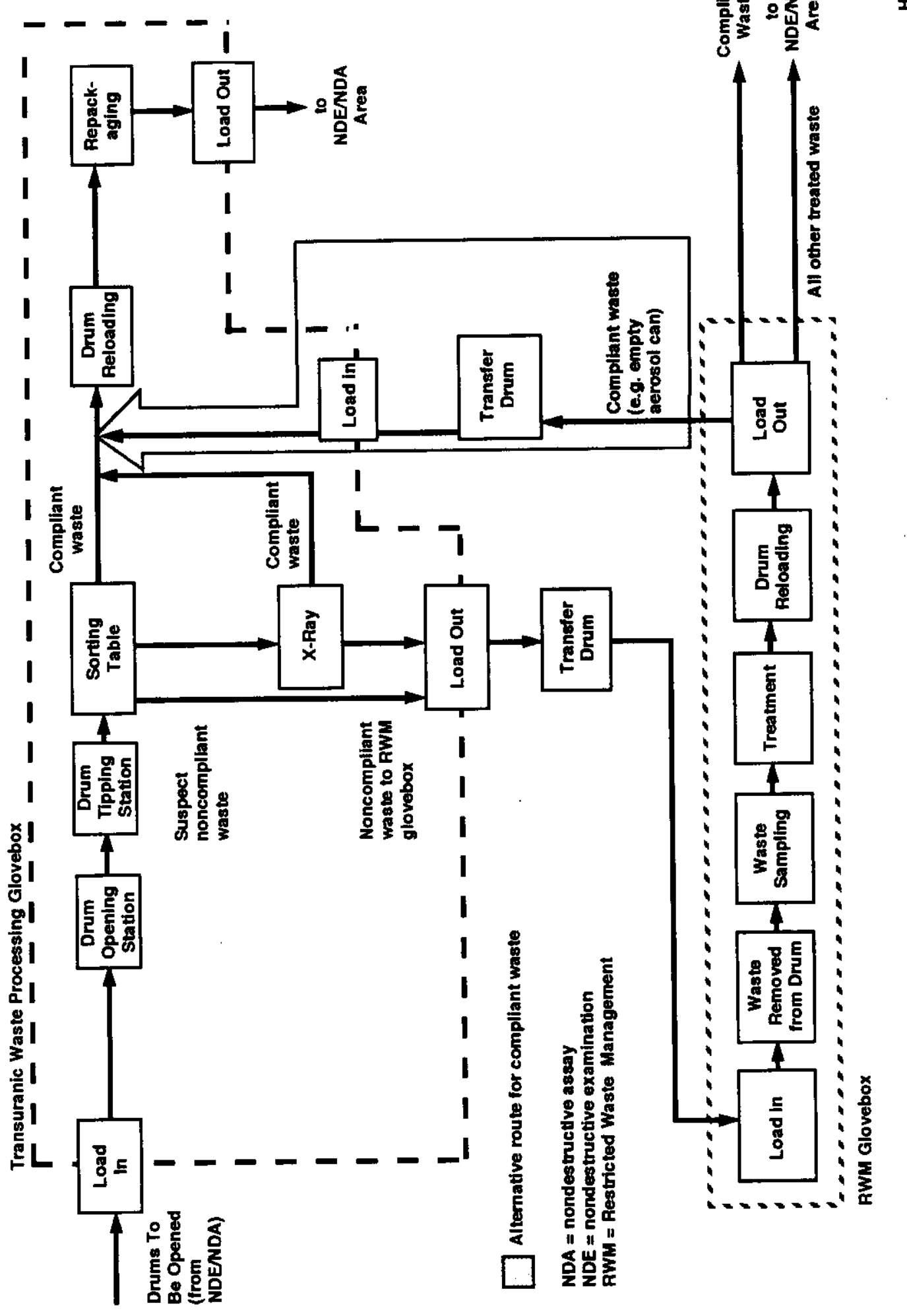

Figure 5. Flow Diagram through Transuranic Waste Gloveboxes. 
DOE/RL-2000-34, Rev. 0

$12 / 2000$

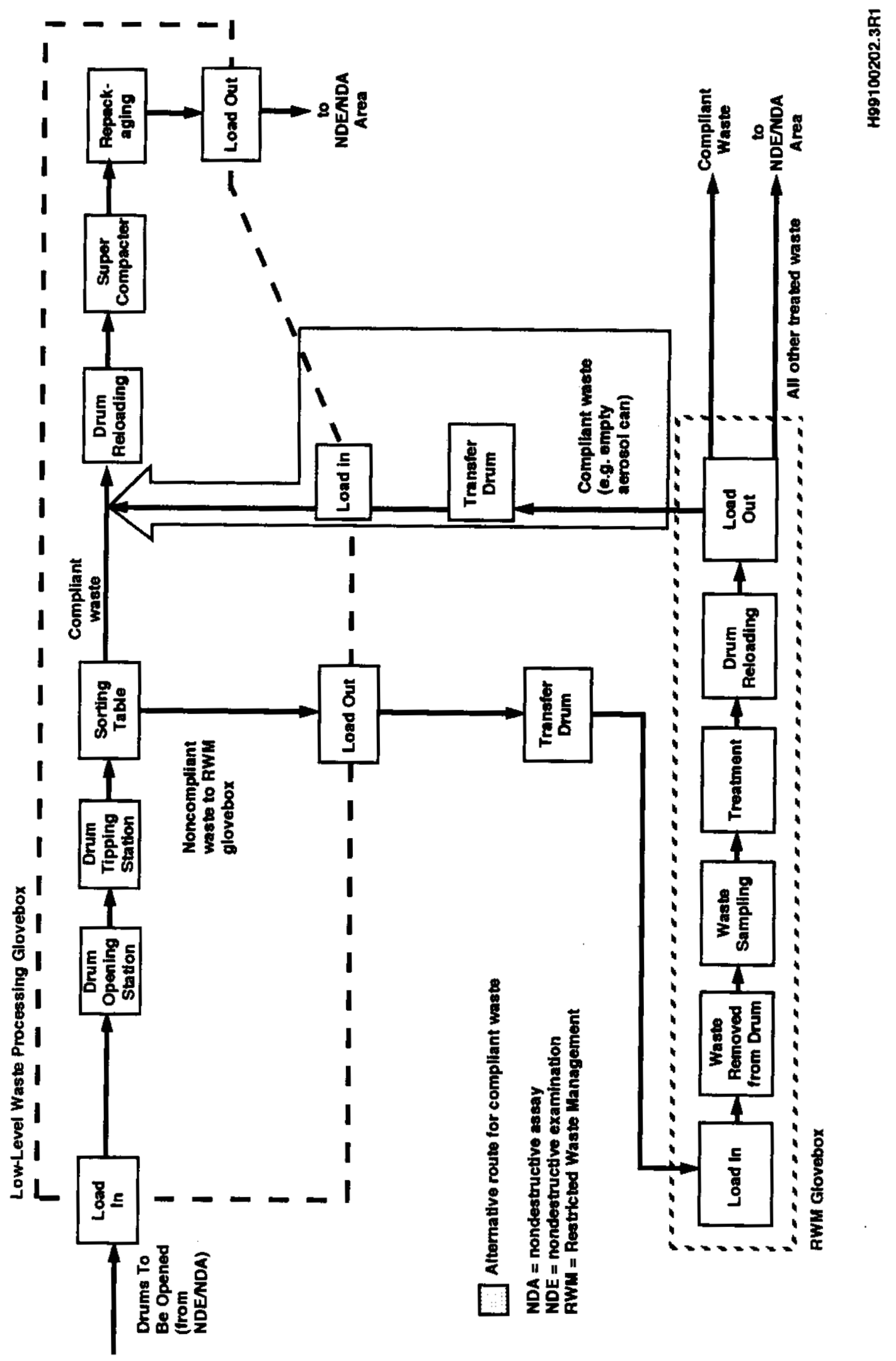

Figure 6. Flow Diagram through Low-Level Processing Glovebox. 


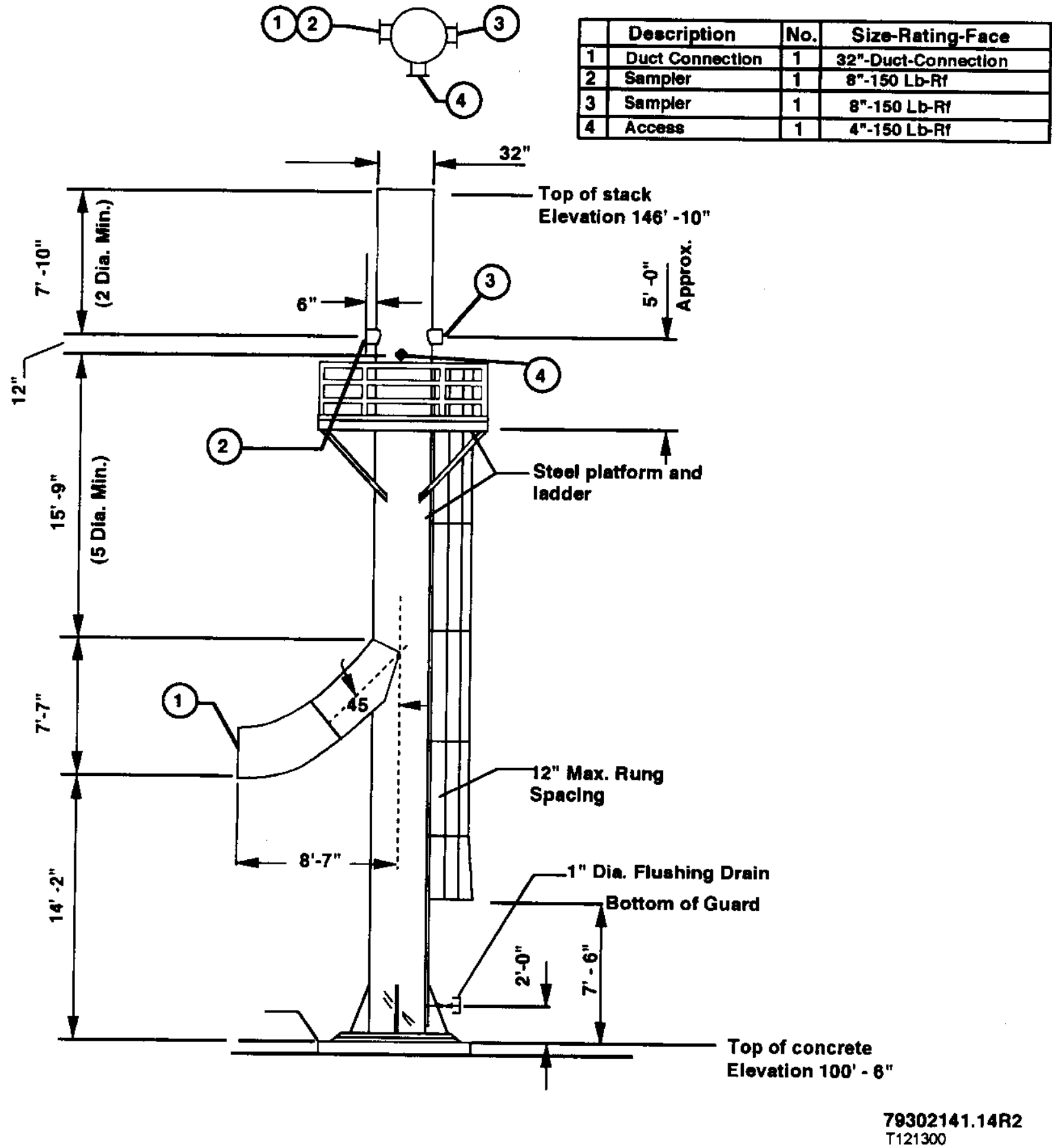

Figure 7. Waste Receiving and Processing Facility Stack. 


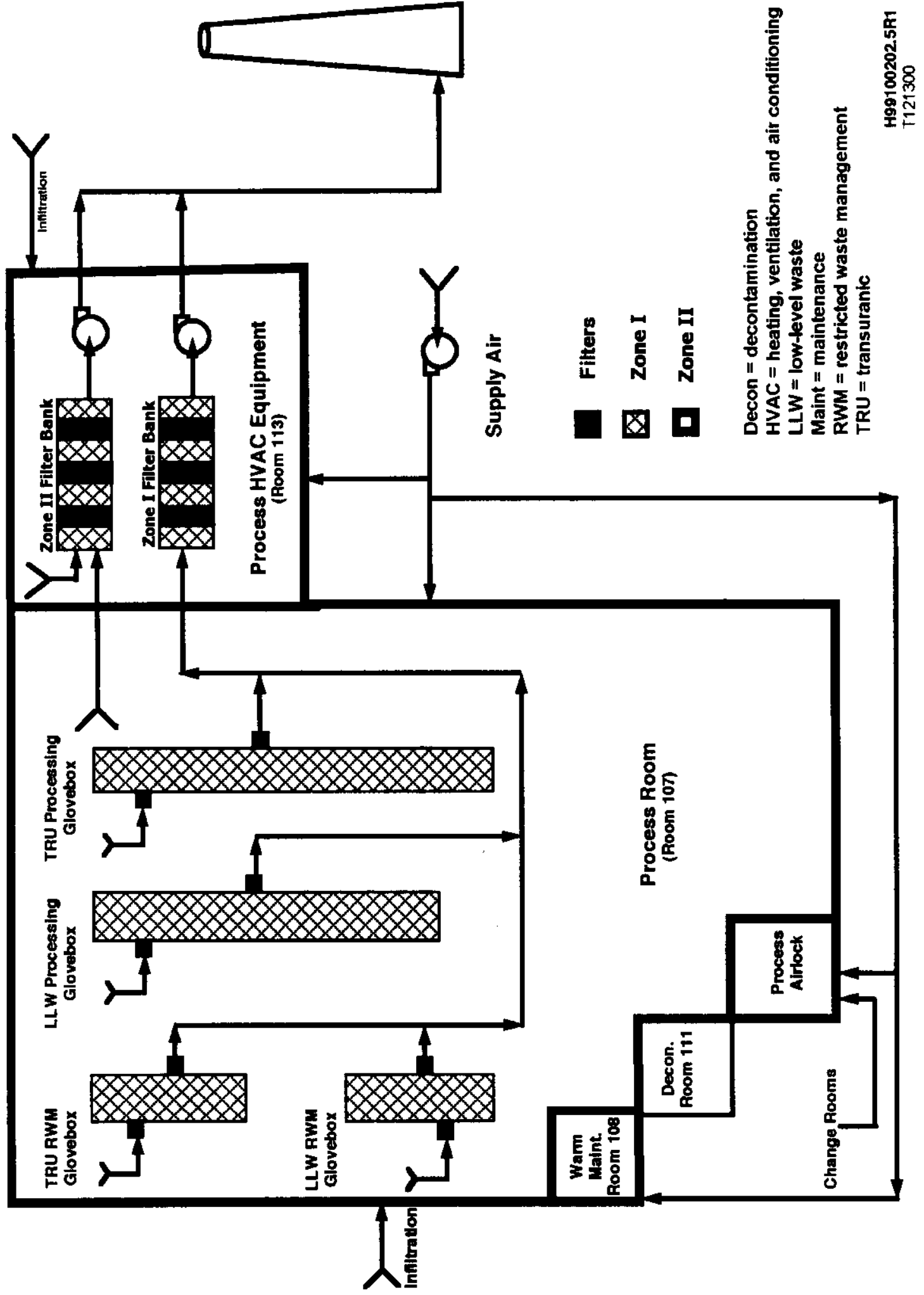

Figure 8. Schematic of Zone I and Zone II Ventilation System. 


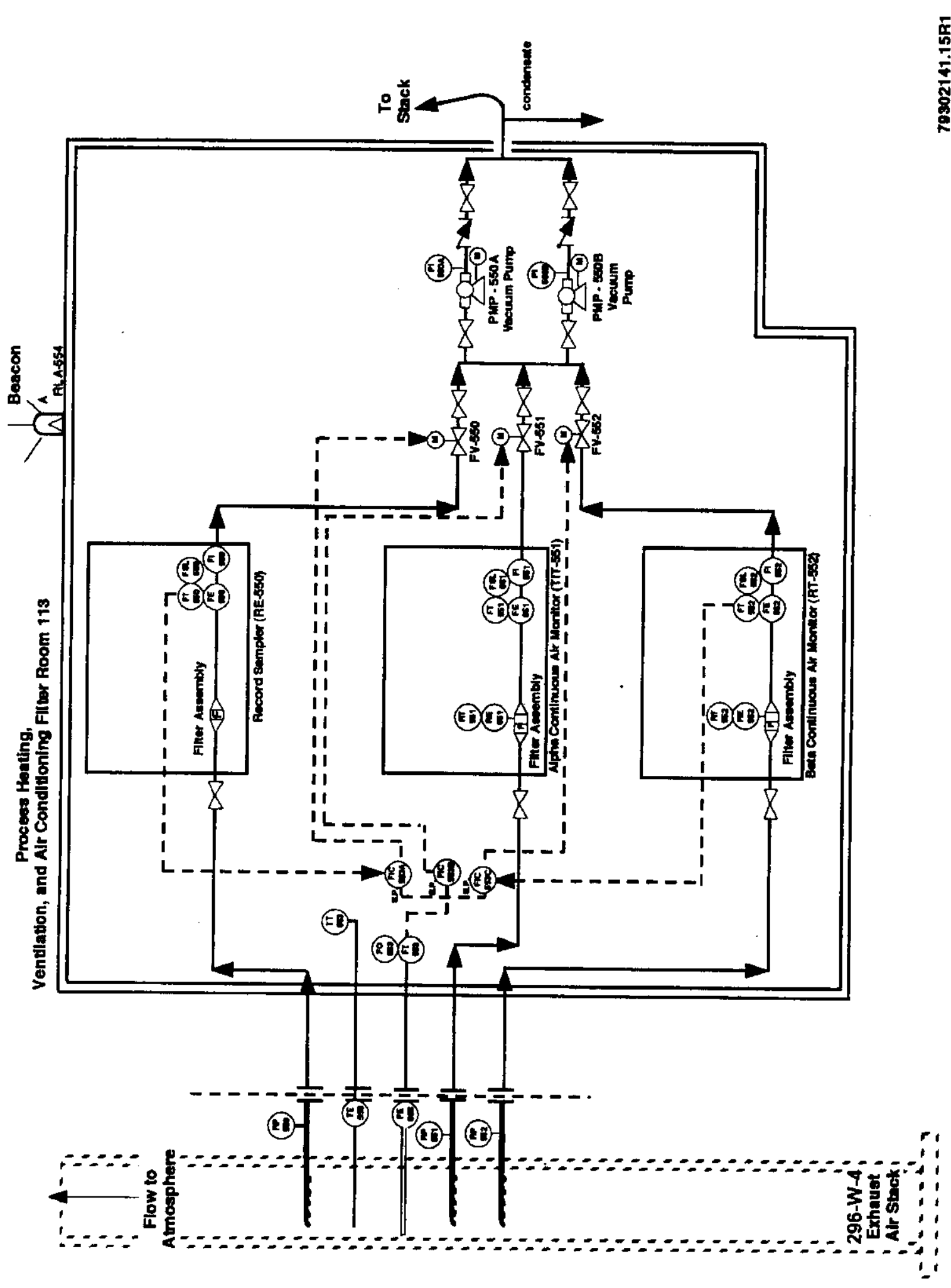

Figure 9. Waste Receiving and Processing Facility Stack Monitoring and Sampling Systems. 
DOE/RL-2000-34, Rev. 0
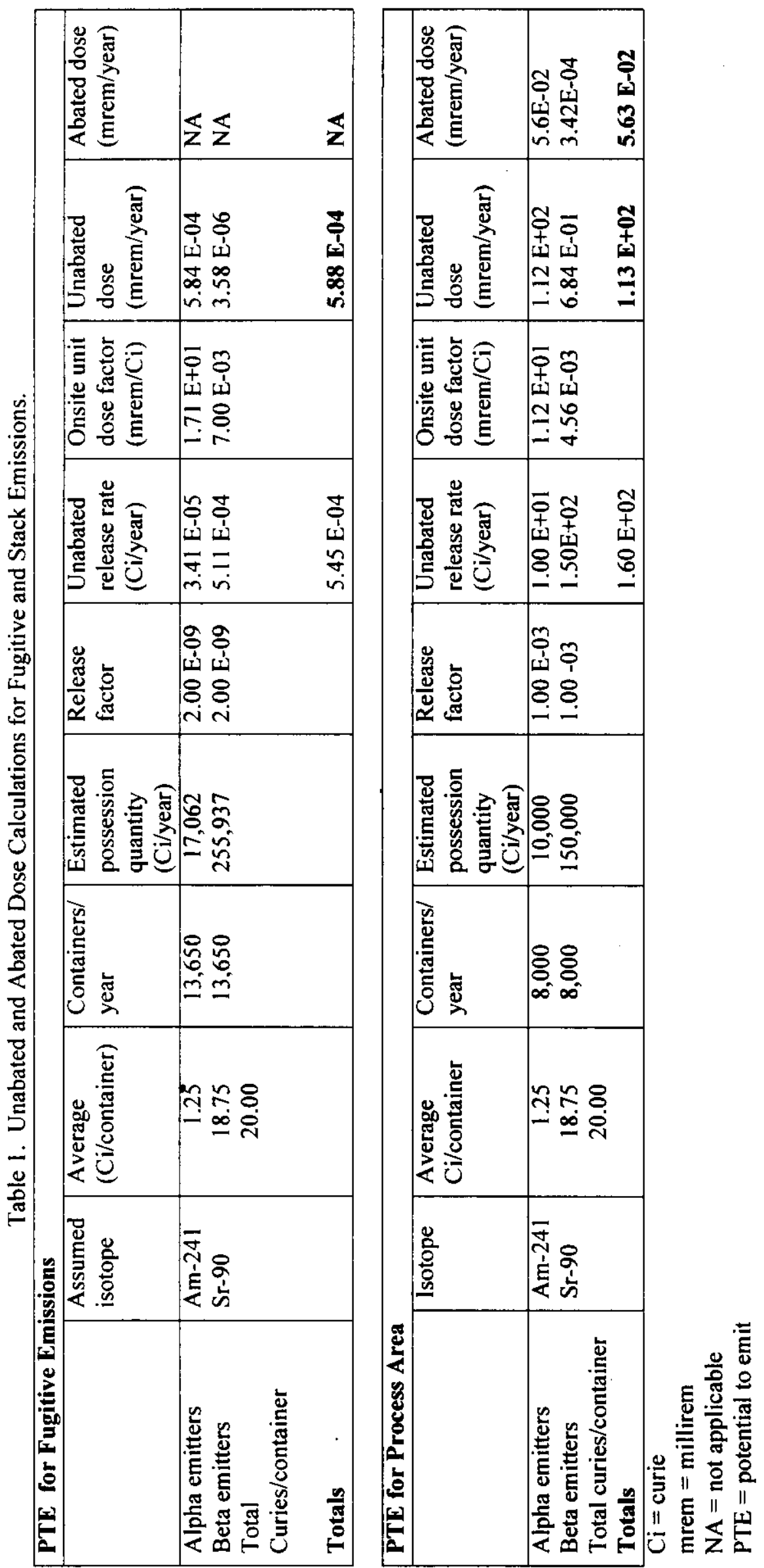

$12 / 2000$ 
DOE/RL-2000-34, Rev. 0

$12 / 2000$

\author{
ATTACHMENT 1 \\ CALCULATION OF DOSE FROM 200 WEST AREA TO \\ ONSITE MEMBER OF THE PUBLIC
}


This page is intentionally left blank 


\author{
L. H. Staven \\ May 9,2000 \\ Pacific Northwest National Laboratory \\ Richland, Washington
}


DOE/RL-2000-34, Rev. 0

$12 / 2000$

This page intentionally left blank. 


\section{INTRODUCTION}

Dose estimates for unit $\mathrm{Ci}$ releases of selected radionuclides were calculated for emissions from the 200 West Area on the Hanford Site. These estimates are used as generic dose conversion factors to determine emission monitoring requirements for the 200 West Area facilities.

\section{METHODS FOR CALCULATING RADIATION DOSE}

The desktop computer version of the Clean Air Act Compliance code (Parks 1992) was used to calculate the effective dose equivalent (EDE) to the receptors from routine chronic 10- and 40-meter releases from the 200 West Area.

\section{RELEASE AND ATMOSPHERIC TRANSPORT ASSUMPTIONS}

The Reduction and Oxidation (REDOX) Facility was selected as the most conservative facility to model 200 West Area emissions because this facility is the closest to the receptors. One $\mathrm{Ci}$ of each selected radionuclide was assumed to leave the facility at 10- and 40-meter heights with no plume rise.

The 200 West Area meteorological data were used to model the direction and probability of dispersion. Data were collected at the 10-meter height for calendar years 1983 through 1996 in the 200 West Area.

Locations around the Hanford Site boundaries, and selected onsite non-U.S. Department of Energy (DOE) facilities, were modeled to determine the locations with the highest chi/Q, or the probability to have the greatest integrated air concentration over the course of a year. Those sites with the highest chi/Q were selected to represent the location of the receptors.

\section{EXPOSURE AND DOSE ASSUMPTIONS}

The dose from the non-ingestion pathways (i.e., inhalation and external) is proportional to the amount of time a receptor spends at the point of exposure. The reported doses for the onsite receptors conservatively assume that the individual is onsite the entire year, for the full 8,766 hours per year.

The onsite public worker was assumed to consume food grown regionally, that is, where the population is located in a 50-mile radius of the 200 Areas. The ingestion dose is added to the inhalation and external doses.

Hanford Site specific parameters were used as documented in Schreckhise et al., 1990. The default file used for calculations is shown in Attachments 1 and 2.

\section{CALCULATION RESULTS}

Doses were calculated for an onsite member of the public working at LIGO, and are shown in Table ATT-1-1. The location of LIGO relative to the 200 West Area is 18,310 meters to the east by southeast. 


\section{REFERENCES}

Parks, B. S. 1992. User's Guide for CAP88-PC. Version 1.0. 402-B-92-001. Office of Radiation Programs, U.S. Environmental Protection Agency, Las Vegas, Nevada.

Schreckhise, R. G., K. Rhoads, J. S. Davis, B. A. Napier, and J. V. Ramsdell. 1993. Recommended Environmental Dose Calculation Methods and Hanford-Specific Parameters. PNL-3777, Rev. 2. Pacific Northwest Laboratory, Richland Washington. 


\section{Appendix A}

\section{A.1 Hanford Default Average Individual file for CAP88PC}

FILE: DEFAULTP.HAN Hanford Average Ind. Parameters Revised 3/29/00 KR

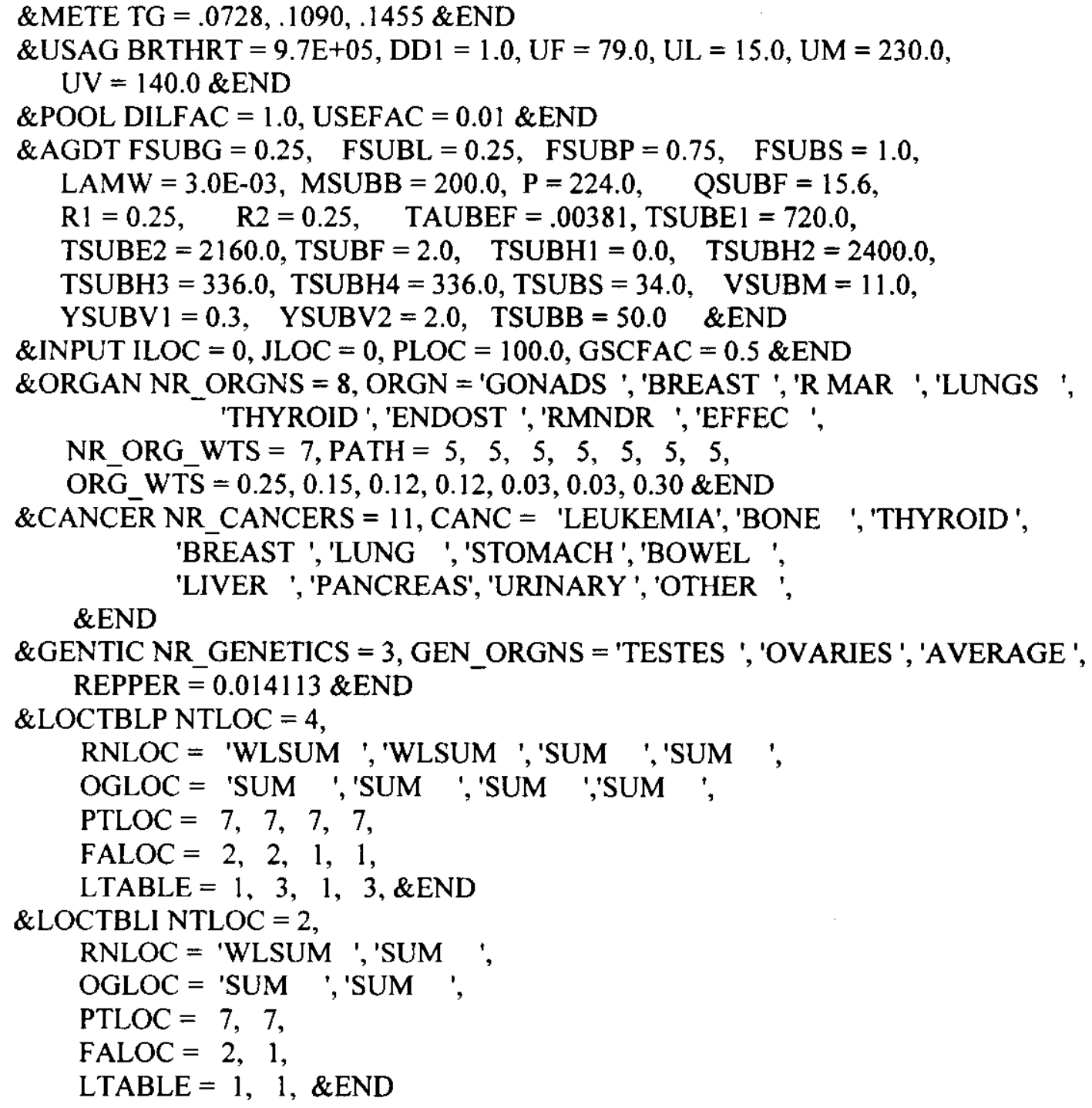

NOTE: The NAMELISTS need to be in the order they are read by the program. If a NAMELIST is not needed it will simply be ignored. The system reads sequentially until it finds a match. 


\section{A.2 Hanford Default maximum individual file for CAP88PC}

FILE: DEFAULTM.HAN Hanford Parameters Revised 6/5/97 KR

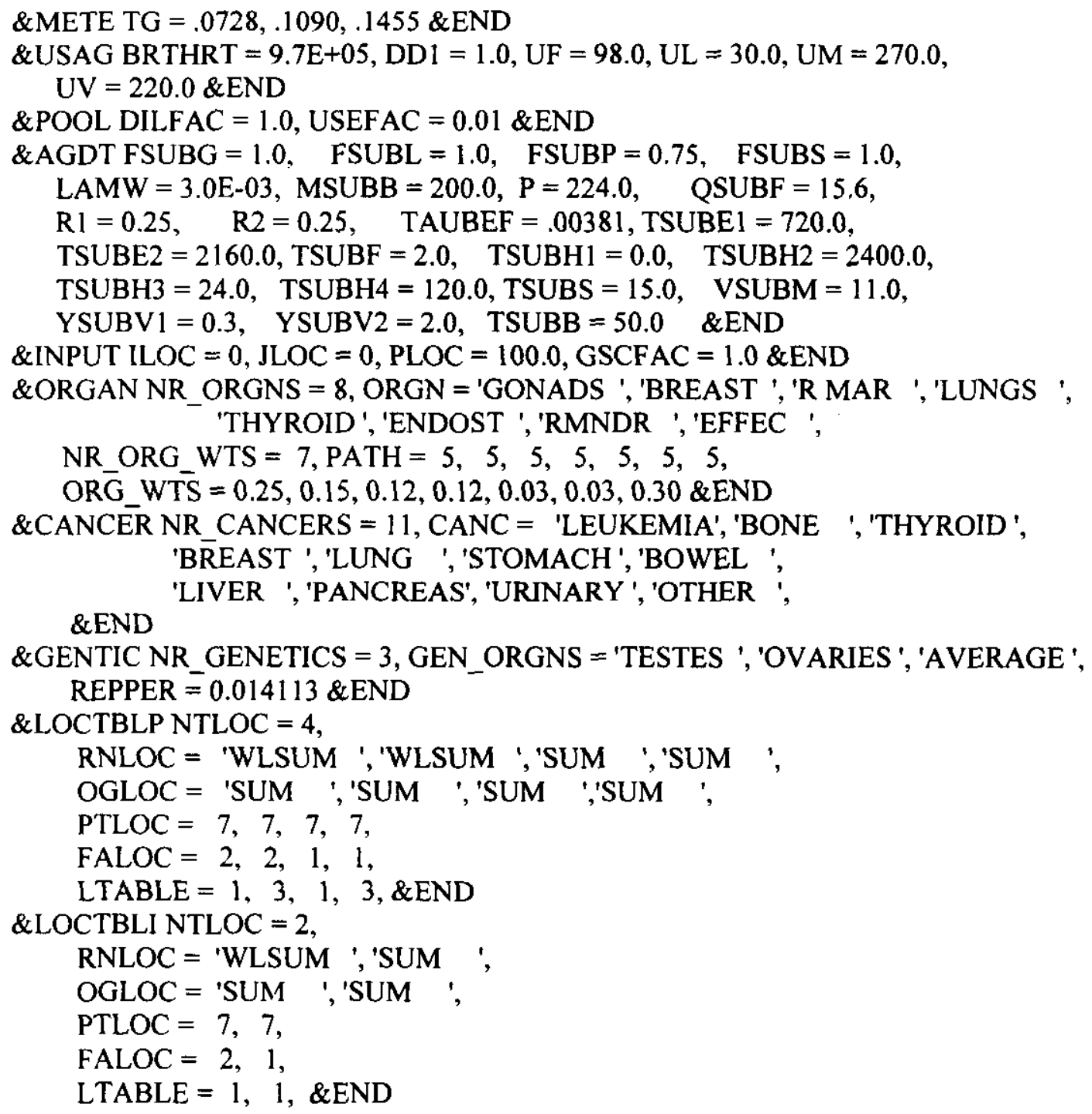

NOTE: The NAMELISTS need to be in the order they are read by the program. If a NAMELIST is not needed it will simply be ignored. The system reads sequentially until it finds a match. 


\begin{tabular}{|c|c|c|c|c|}
\hline \multicolumn{5}{|c|}{$\begin{array}{c}\text { Table ATT-1-2. } 200 \text { West Area -- LIGO Worker (a) CAP88-PC Unit Dose Factors } \\
\text { by Effective Release Height }(40 \mathrm{~m}) \text { with Regional Ingestion }\end{array}$} \\
\hline & $\mathrm{CHI} / \mathrm{q}$ & $8.982 \mathrm{E}-08 \mathrm{~s} / \mathrm{m}^{3}$ & \multicolumn{2}{|c|}{$18310 \mathrm{~m} \mathrm{ESE}$} \\
\hline Nuclide & $\begin{array}{c}\text { No Ingestion } \\
\text { (mrem/yr) }\end{array}$ & $\begin{array}{l}\text { Ingestion Only } \\
\text { (mrem/yr) }\end{array}$ & $\begin{array}{l}\text { Total With Ingestion } \\
(\mathrm{mrem} / \mathrm{yr})\end{array}$ & $\begin{array}{l}\text { Percent } \\
\text { Ingestion }\end{array}$ \\
\hline $\mathrm{H}-3$ & $3.23 \mathrm{E}-06$ & $2.42 \mathrm{E}-06$ & $5.65 \mathrm{E}-06$ & $4.28 \mathrm{E}-01$ \\
\hline $\mathrm{BE}-7$ & $1.72 \mathrm{E}-04$ & $2.93 \mathrm{E}-07$ & $1.72 \mathrm{E}-04$ & $1.70 \mathrm{E}-03$ \\
\hline BE-10 (b) & $(\mathrm{Sr}-90)$ & $(\mathrm{Sr}-90)$ & $\overline{(S r-90)}$ & \\
\hline$C-11$ & $5.4 \overline{1 E}-07$ & $0.00 \mathrm{E}+00$ & $5.41 \mathrm{E}-07$ & $0.00 \mathrm{E}+00$ \\
\hline $\mathrm{C}-14$ & $2.96 \mathrm{E}-07$ & $1.69 \mathrm{E}-04$ & $1.69 \mathrm{E}-04$ & $9.98 \mathrm{E}-01$ \\
\hline$C-15(\mathrm{c})$ & $0.00 \overline{\mathrm{E}}+00$ & $0.00 \mathrm{E}+00$ & $0.00 \mathrm{E}+00$ & \\
\hline$\overline{\mathrm{N}}-13$ & $6.69 \mathrm{E}-08$ & $0.00 \mathrm{E}+00$ & $6.69 \mathrm{E}-08$ & $0.00 \mathrm{E}+00$ \\
\hline $0-15$ & $6.37 \bar{E}-14$ & $0.00 \overline{\mathrm{E}}+00$ & $6.37 \mathrm{E}-14$ & $0.00 \mathrm{E}+00$ \\
\hline F-18 & $7.06 \mathrm{E}-06$ & $0.00 \mathrm{E}+00$ & $7.06 \mathrm{E}-06$ & $0.00 \mathrm{E}+00$ \\
\hline$\overline{\mathrm{NA}}-22$ & $1.12 \mathrm{E}-01$ & $1.04 \mathrm{E}-03$ & $1.13 \mathrm{E}-01$ & $9.18 \mathrm{E}-03$ \\
\hline NA-24 & $1.90 \mathrm{E}-04$ & $3.46 \mathrm{E}-07$ & $1.90 \mathrm{E}-04$ & $1.82 \mathrm{E}-03$ \\
\hline $\mathrm{P}-32$ & $1.24 \mathrm{E}-04$ & $1.28 \mathrm{E}-04$ & $2.52 \mathrm{E}-04$ & $5.08 \mathrm{E}-01$ \\
\hline S-35 & $6.10 \mathrm{E}-06$ & $2.52 \mathrm{E}-05$ & $3.13 \mathrm{E}-05$ & $8.05 \mathrm{E}-01$ \\
\hline$\overline{\mathrm{AR}}-41$ & $7.16 \mathrm{E}-06$ & $0.00 \mathrm{E}+00$ & $7.16 \mathrm{E}-06$ & $0.00 \mathrm{E}+00$ \\
\hline$\overline{\mathrm{K}}-\overline{40}$ & $6.62 \mathrm{E}-02$ & $2.82 \mathrm{E}-03$ & $6.90 \mathrm{E}-02$ & $4.08 \mathrm{E}-02$ \\
\hline $\mathrm{CA}-41$ & $9.98 \mathrm{E}-06$ & $0.00 \mathrm{E}+00$ & $9.98 \overline{\mathrm{E}-06}$ & $0.00 \mathrm{E}+00$ \\
\hline $\mathrm{SC}-46$ & $1.04 \mathrm{E}-02$ & $4.52 \mathrm{E}-05$ & $1.04 \mathrm{E}-02$ & $4.33 \mathrm{E}-03$ \\
\hline CR-51 & $6.35 \mathrm{E}-05$ & $5.32 \overline{\mathrm{E}}-07$ & $6.40 \bar{E}-05$ & $8.31 \mathrm{E}-03$ \\
\hline MN-54 & $1.56 \mathrm{E}-02$ & $1.06 \mathrm{E}-05$ & $1.56 \mathrm{E}-02$ & $6.81 \mathrm{E}-04$ \\
\hline $\mathrm{MN}-56$ & $2.13 \overline{\mathrm{E}}-05$ & $0.00 \mathrm{E}+00$ & $2.13 \mathrm{E}-05$ & $0.00 \mathrm{E}+00$ \\
\hline FE-55 & $3.98 \overline{\mathrm{E}-05}$ & $8.11 \mathrm{E}-06$ & $4.79 \mathrm{E}-05$ & $1.69 \mathrm{E}-01$ \\
\hline FE-59 & $3.21 \mathrm{E}-03$ & $4.34 \mathrm{E}-05$ & $3.25 \mathrm{E}-03$ & $1.33 \mathrm{E}-02$ \\
\hline $\mathrm{CO}-57$ & $2.42 \mathrm{E}-03$ & $1.68 \mathrm{E}-05$ & $2.44 \mathrm{E}-03$ & $6.88 \mathrm{E}-03$ \\
\hline $\mathrm{CO}-58$ & $4.41 \mathrm{E}-03$ & $3 . \overline{54 E-05}$ & $4.45 \mathrm{E}-03$ & $7.96 \mathrm{E}-03$ \\
\hline$\overline{\mathrm{CO}}-60$ & $2.33 \mathrm{E}-01$ & $4.26 \mathrm{E}-04$ & $2.3 \overline{3} \mathrm{E}-01$ & $1.82 \mathrm{E}-03$ \\
\hline NI-59 & $2.20 \mathrm{E}-04$ & $2.31 \mathrm{E}-06$ & $2.22 \mathrm{E}-04$ & $1.04 \mathrm{E}-02$ \\
\hline NI-63 & $4.69 \mathrm{E}-05$ & $6.06 \mathrm{E}-06$ & $5.30 \mathrm{E}-05$ & $1 . \overline{14 \mathrm{E}-01}$ \\
\hline NI-65 & $8 . \overline{38 \mathrm{E}-06}$ & $0.00 \mathrm{E}+00$ & $8.38 \mathrm{E}-06$ & $0.00 \mathrm{E}+00$ \\
\hline CU-64 & $1.35 \mathrm{E}-05$ & $2.66 \mathrm{E}-09$ & $1.35 \mathrm{E}-05$ & $1.97 \mathrm{E}-04$ \\
\hline $\mathrm{ZN}-65$ & $8.34 \mathrm{E}-03$ & $1.07 \mathrm{E}-03$ & $9 . \overline{41 \mathrm{E}-03}$ & $1.13 \mathrm{E}-01$ \\
\hline $\mathrm{ZN}-69$ & $2.78 \mathrm{E}-07$ & $0.00 \mathrm{E}+00$ & $2.78 \mathrm{E}-07$ & $0.00 \mathrm{E}+00$ \\
\hline $\mathrm{ZN}-69 \mathrm{M}$ & $3.56 \mathrm{E}-\overline{05}$ & $5.85 \mathrm{E}-08$ & $3.57 \mathrm{E}-05$ & $1.64 \mathrm{E}-03$ \\
\hline GA-67 & $4.46 \mathrm{E}-05$ & $2.66 \mathrm{E}-08$ & $4.46 \mathrm{E}-05$ & $5.96 \mathrm{E}-04$ \\
\hline AS-76 & $1.17 \mathrm{E}-04$ & $2.66 \mathrm{E}-08$ & $1.17 \mathrm{E}-04$ & $2.27 \mathrm{E}-04$ \\
\hline SE-79 (b) & (Pu-241) & $(\mathrm{Pu}-241)$ & (Pu-241) & \\
\hline BR-82 & $2.72 \mathrm{E}-04$ & $2.07 \mathrm{E}-06$ & $2.74 \mathrm{E}-04$ & $7.57 \mathrm{E}-03$ \\
\hline BR-83 & $6.30 \mathrm{E}-08$ & $0.00 \overline{\mathrm{E}+00}$ & $6.30 \mathrm{E}-08$ & $0.00 \mathrm{E}+00$ \\
\hline BR-84 & $2.41 \mathrm{E}-06$ & $0.00 \mathrm{E}+00$ & $2.41 \mathrm{E}-06$ & $0.00 \mathrm{E}+00$ \\
\hline BR-85 & $6.45 \mathrm{E}-13$ & $0.00 \mathrm{E}+00$ & $6.45 \mathrm{E}-13$ & $0.00 \overline{\mathrm{E}}+00$ \\
\hline KR-83M & $1.29 \overline{\mathrm{E}-09}$ & $0.00 \mathrm{E}+00$ & $1.29 \mathrm{E}-09$ & $0.00 \mathrm{E}+0 \overline{0}$ \\
\hline
\end{tabular}




\begin{tabular}{|c|c|c|c|c|}
\hline Nuclide & $\begin{array}{c}\text { No Ingestion } \\
\text { (mrem/yr) }\end{array}$ & $\begin{array}{c}\text { Ingestion Only } \\
\text { (mrem/yr) }\end{array}$ & $\begin{array}{l}\text { Total With Ingestion } \\
\text { (mrem/yr) }\end{array}$ & $\begin{array}{c}\text { Percent } \\
\text { Ingestion }\end{array}$ \\
\hline KR-85 & $4.78 \mathrm{E}-08$ & $0.00 \mathrm{E}+00$ & $4.78 \mathrm{E}-08$ & $0.00 \mathrm{E}+00$ \\
\hline KR-85M & $1.48 \mathrm{E}-06$ & $0.00 \mathrm{E}+00$ & $1.48 \mathrm{E}-06$ & $0.00 \mathrm{E}+00$ \\
\hline KR-87 & $3.49 \mathrm{E}-06$ & $0.00 \mathrm{E}+00$ & $3.49 \mathrm{E}-06$ & $0.00 \mathrm{E}+00$ \\
\hline KR-88 & $1.66 \mathrm{E}-05$ & $0.00 \mathrm{E}+00$ & $1.66 \mathrm{E}-05$ & $0.00 \mathrm{E}+00$ \\
\hline KR-89 & $6.83 \mathrm{E}-11$ & $0.00 \mathrm{E}+00$ & $6.83 \mathrm{E}-11$ & $0.00 \mathrm{E}+00$ \\
\hline KR-90 (c) & $4.20 \mathrm{E}-37$ & $0.00 \mathrm{E}+00$ & $4.20 \mathrm{E}-37$ & \\
\hline RB-86 & 2.71E-04 & $1.17 \mathrm{E}-04$ & $3.88 \mathrm{E}-04$ & $3.01 \mathrm{E}-01$ \\
\hline RB-87 & $1.52 \mathrm{E}-04$ & $5.25 \mathrm{E}-04$ & $6.77 \mathrm{E}-04$ & $7.75 \mathrm{E}-01$ \\
\hline RB-88 & $3.27 \mathrm{E}-07$ & $0.00 \mathrm{E}+00$ & $3.27 \mathrm{E}-07$ & $0.00 \mathrm{E}+00$ \\
\hline RB-89 & $5.98 \mathrm{E}-07$ & $0.00 \mathrm{E}+00$ & $5.98 \mathrm{E}-07$ & $0.00 \mathrm{E}+00$ \\
\hline RB-90 & $7.36 \mathrm{E}-12$ & $0.00 \mathrm{E}+00$ & $7.36 \mathrm{E}-12$ & $0.00 \mathrm{E}+00$ \\
\hline RB-90M & $2.09 \mathrm{E}-09$ & $0.00 \mathrm{E}+00$ & $2.09 \mathrm{E}-09$ & $0.00 \mathrm{E}+00$ \\
\hline SR-89 & $1.34 \mathrm{E}-04$ & $3.63 \mathrm{E}-05$ & $1.70 \mathrm{E}-04$ & $2.13 \mathrm{E}-01$ \\
\hline SR-90 & $4.56 \mathrm{E}-03$ & $4.15 \mathrm{E}-03$ & $8.71 \mathrm{E}-03$ & $4.77 \mathrm{E}-01$ \\
\hline SR-91 & $3.83 \mathrm{E}-05$ & $2.66 \mathrm{E}-09$ & $3.83 \mathrm{E}-05$ & $6.94 \mathrm{E}-05$ \\
\hline SR-92 & $1.94 \mathrm{E}-05$ & $0.00 \mathrm{E}+00$ & $1.94 \mathrm{E}-05$ & $0.00 \mathrm{E}+00$ \\
\hline$Y-90$ & $1.87 \mathrm{E}-04$ & $2.13 \mathrm{E}-07$ & $1.87 \mathrm{E}-04$ & $1.14 \mathrm{E}-03$ \\
\hline$Y-90 M$ & $7.16 \mathrm{E}-06$ & $0.00 \mathrm{E}+00$ & $7.16 \mathrm{E}-06$ & $0.00 \mathrm{E}+00$ \\
\hline Y-91 & $1.02 \mathrm{E}-03$ & $2.13 \mathrm{E}-05$ & $1.04 \mathrm{E}-03$ & $2.04 \mathrm{E}-02$ \\
\hline $\mathrm{Y}-91 \mathrm{M}$ & $1.44 \mathrm{E}-06$ & $0.00 \mathrm{E}+00$ & $1.44 \mathrm{E}-06$ & $0.00 \mathrm{E}+00$ \\
\hline Y-92 & $1.77 \mathrm{E}-05$ & $0.00 \mathrm{E}+00$ & $1.77 \mathrm{E}-05$ & $0.00 \mathrm{E}+00$ \\
\hline $\mathrm{Y}-93$ & $5.03 \mathrm{E}-05$ & $0.00 \mathrm{E}+00$ & $5.03 \mathrm{E}-05$ & $0.00 \mathrm{E}+00$ \\
\hline ZR-93 & $9.86 \mathrm{E}-04$ & $6.38 \mathrm{E}-06$ & $9.92 \mathrm{E}-04$ & $6.43 \mathrm{E}-03$ \\
\hline ZR-95 & $3.17 \mathrm{E}-03$ & $1.41 \mathrm{E}-05$ & $3.18 \mathrm{E}-03$ & $4.43 \mathrm{E}-03$ \\
\hline NB-93M & $8.24 \mathrm{E}-04$ & $9.28 \mathrm{E}-05$ & $9.17 \mathrm{E}-04$ & $1.01 \mathrm{E}-01$ \\
\hline NB-94 & $7.75 \mathrm{E}-01$ & $1.60 \mathrm{E}-03$ & $7.77 \mathrm{E}-01$ & $2.05 \mathrm{E}-03$ \\
\hline NB-95 & $1.77 \mathrm{E}-03$ & $1.69 \mathrm{E}-04$ & $1.94 \mathrm{E}-03$ & $8.74 \mathrm{E}-02$ \\
\hline NB-95M & $6.49 \mathrm{E}-05$ & $1.10 \mathrm{E}-05$ & $7.59 \mathrm{E}-05$ & $1.45 \mathrm{E}-01$ \\
\hline NB-97 & $3.46 \mathrm{E}-06$ & $0.00 \mathrm{E}+00$ & $3.46 \mathrm{E}-06$ & $0.00 \mathrm{E}+00$ \\
\hline NB-97M & $7.48 \mathrm{E}-22$ & $0.00 \mathrm{E}+00$ & $7.48 \mathrm{E}-22$ & $0.00 \mathrm{E}+00$ \\
\hline $\mathrm{MO}-93$ & $2.76 \mathrm{E}-03$ & $0.00 \mathrm{E}+00$ & $2.76 \mathrm{E}-03$ & $0.00 \mathrm{E}+00$ \\
\hline$M O-99$ & $1.15 E-04$ & $7.98 E-07$ & $1.16 E-04$ & $6.89 E-03$ \\
\hline MO-99+D & $1.42 \mathrm{E}-04$ & $7.98 \mathrm{E}-07$ & $1.43 \mathrm{E}-04$ & $5.60 \mathrm{E}-03$ \\
\hline TC-97 & $3.08 \mathrm{E}-03$ & $1.80 \mathrm{E}-04$ & $3.26 \mathrm{E}-03$ & $5.53 \mathrm{E}-02$ \\
\hline TC-99 & $1.73 \mathrm{E}-04$ & $1.54 \mathrm{E}-03$ & $1.71 \mathrm{E}-03$ & $8.99 \mathrm{E}-01$ \\
\hline \begin{tabular}{|l|} 
TC-101 \\
\end{tabular} & $6.93 \mathrm{E}-08$ & $0.00 \mathrm{E}+00$ & $6.93 \mathrm{E}-08$ & $0.00 \mathrm{E}+00$ \\
\hline RU-97 & $5.41 \mathrm{E}-05$ & $2.66 \mathrm{E}-08$ & $5.41 \mathrm{E}-05$ & $4.91 \mathrm{E}-04$ \\
\hline RU-103 & $1.37 \mathrm{E}-03$ & $6.65 \mathrm{E}-06$ & $1.38 \mathrm{E}-03$ & $4.83 \mathrm{E}-03$ \\
\hline RU-105 & $2.06 \mathrm{E}-05$ & $0.00 \mathrm{E}+00$ & $2.06 \mathrm{E}-05$ & $0.00 \mathrm{E}+00$ \\
\hline RU-106 & $9.81 \mathrm{E}-03$ & $1.01 \mathrm{E}-04$ & $9.91 \mathrm{E}-03$ & $1.02 \mathrm{E}-02$ \\
\hline RH-105 & $2.91 \mathrm{E}-05$ & $8.88 \mathrm{E}-07$ & $3.00 \mathrm{E}-05$ & $2.96 \mathrm{E}-02$ \\
\hline RH-105M & $2.27 \mathrm{E}-28$ & $0.00 \mathrm{E}+00$ & $2.27 \mathrm{E}-28$ & $0.00 \mathrm{E}+00$ \\
\hline RH-106 (c) & $0.00 \mathrm{E}+00$ & $0.00 \mathrm{E}+00$ & $0.00 \mathrm{E}+00$ & \\
\hline PD-107 & $2.61 \mathrm{E}-04$ & $5.40 \mathrm{E}-06$ & $2.66 \mathrm{E}-04$ & $2.03 \mathrm{E}-02$ \\
\hline PD-109 & $2.90 \mathrm{E}-05$ & $1.06 \mathrm{E}-07$ & 2.91E-05 & $3.65 \mathrm{E}-03$ \\
\hline $\mathrm{AG}-109 \mathrm{M}$ & $4.61 \mathrm{E}-33$ & $0.00 \mathrm{E}+00$ & $4.61 \mathrm{E}-33$ & $0.00 \mathrm{E}+00$ \\
\hline AG-110 (c) & $0.00 \mathrm{E}+00$ & $0.00 \mathrm{E}+00$ & $0.00 \mathrm{E}+00$ & \\
\hline
\end{tabular}




\begin{tabular}{|c|c|c|c|c|}
\hline Nuclide & $\begin{array}{c}\text { No Ingestion } \\
\text { (mrem/yr) }\end{array}$ & $\begin{array}{l}\text { Ingestion Only } \\
\text { (mrem/yr) }\end{array}$ & $\begin{array}{l}\text { Total With Ingestion } \\
\text { (mrem/yr) }\end{array}$ & $\begin{array}{c}\text { Percent } \\
\text { Ingestion }\end{array}$ \\
\hline AG-110M & $4.13 \mathrm{E}-02$ & $3.75 \mathrm{E}-04$ & $4.17 \mathrm{E}-02$ & $9.00 \mathrm{E}-03$ \\
\hline $\mathrm{AG}-111$ & $1.46 \mathrm{E}-04$ & $4.96 \mathrm{E}-05$ & $1.96 \mathrm{E}-04$ & $2.53 \overline{\mathrm{E}}-01$ \\
\hline CD-113 (b) & (Pu-241) & $(\mathrm{Pu}-241)$ & $(\mathrm{Pu}-241)$ & \\
\hline CD-113M (b) & (Pu-24l) & (Pu-241) & (Pu-241) & \\
\hline CD-115 & $1.22 \mathrm{E}-04$ & $7.45 \mathrm{E}-07$ & $1.23 \mathrm{E}-04$ & $6.07 \mathrm{E}-03$ \\
\hline $\mathrm{CD}-115 \mathrm{M}$ & $9.53 \mathrm{E}-04$ & $5.13 \mathrm{E}-05$ & $1.00 \mathrm{E}-03$ & $5.11 \mathrm{E}-02$ \\
\hline IN-113M & $1.88 \mathrm{E}-06$ & $0.00 \mathrm{E}+00$ & $1.88 \mathrm{E}-06$ & $0.00 \mathrm{E}+00$ \\
\hline IN-115 & $2.11 \mathrm{E}-02$ & $1.17 \mathrm{E}-03$ & $2.23 \mathrm{E}-02$ & $5.27 \mathrm{E}-02$ \\
\hline $\mathrm{IN}-115 \mathrm{M}$ & $4.78 \mathrm{E}-06$ & $0.00 \mathrm{E}+00$ & $4.78 \mathrm{E}-06$ & $0.00 \mathrm{E}+00$ \\
\hline $\mathrm{SN}-113$ & $3.34 \mathrm{E}-04$ & $1.06 \mathrm{E}-04$ & $4.40 \mathrm{E}-04$ & $2.42 \mathrm{E}-01$ \\
\hline $\mathrm{SN}-123$ & $5.05 \mathrm{E}-05$ & $0.00 \mathrm{E}+00$ & $5.05 \mathrm{E}-05$ & $0.00 \mathrm{E}+00$ \\
\hline $\mathrm{SN}-125$ & $5.01 \mathrm{E}-04$ & $3.24 \mathrm{E}-05$ & $5.33 \mathrm{E}-04$ & $6.08 \mathrm{E}-02$ \\
\hline SN-126 & $3.08 \mathrm{E}-02$ & $1.03 \mathrm{E}-03$ & $3.18 \mathrm{E}-02$ & $3.23 \mathrm{E}-02$ \\
\hline SB-124 & $6.92 \mathrm{E}-03$ & $2.39 \mathrm{E}-05$ & $6.94 \mathrm{E}-03$ & $3.45 \mathrm{E}-03$ \\
\hline SB-125 & $2.51 \mathrm{E}-02$ & $1.06 \mathrm{E}-05$ & $2.51 \mathrm{E}-02$ & $4.24 \mathrm{E}-04$ \\
\hline SB-126 & $2.38 \mathrm{E}-03$ & $8.51 \mathrm{E}-06$ & $2.39 \mathrm{E}-03$ & $3.56 \mathrm{E}-03$ \\
\hline SB-126M & $7.21 \mathrm{E}-07$ & $0.00 \mathrm{E}+00$ & $7.21 \mathrm{E}-07$ & $0.00 \mathrm{E}+00$ \\
\hline SB-127 & $2.91 \mathrm{E}-04$ & $5.85 \mathrm{E}-07$ & $2.92 \mathrm{E}-04$ & $2.01 \mathrm{E}-03$ \\
\hline TE-125M & $2.25 \mathrm{E}-04$ & $2.35 \mathrm{E}-05$ & $2.49 \mathrm{E}-04$ & $9.47 \mathrm{E}-02$ \\
\hline TE-127 & $7.24 \mathrm{E}-06$ & $0.00 \mathrm{E}+00$ & $7.24 \mathrm{E}-06$ & $0.00 \mathrm{E}+00$ \\
\hline TE-127M & $4.89 \mathrm{E}-04$ & $6.81 \mathrm{E}-05$ & $5.57 \mathrm{E}-04$ & $1.22 \mathrm{E}-01$ \\
\hline TE-129 & $9.14 \mathrm{E}-07$ & $0.00 \mathrm{E}+00$ & $9.14 \mathrm{E}-07$ & $0.00 \mathrm{E}+00$ \\
\hline TE-129M & $5.68 \mathrm{E}-04$ & $4.71 \mathrm{E}-05$ & $6.15 \mathrm{E}-04$ & $7.65 \mathrm{E}-02$ \\
\hline TE-131 & $4.80 \mathrm{E}-07$ & $0.00 \mathrm{E}+00$ & $4.80 \bar{E}-07$ & $0.00 \mathrm{E}+00$ \\
\hline TE-131M & $2.07 \mathrm{E}-04$ & $5.32 \mathrm{E}-08$ & $2.07 \mathrm{E}-04$ & $2.57 \mathrm{E}-04$ \\
\hline TE-132 & $2.11 \mathrm{E}-04$ & $7.18 \mathrm{E}-07$ & $2.12 \mathrm{E}-04$ & $3.39 \mathrm{E}-03$ \\
\hline TE-133 & $1.30 \mathrm{E}-07$ & $0.00 \mathrm{E}+00$ & $1.30 \mathrm{E}-07$ & $0.00 \mathrm{E}+00$ \\
\hline TE-133M & $6.48 \mathrm{E}-06$ & $0.00 \mathrm{E}+00$ & $6.48 \mathrm{E}-06$ & $0.00 \mathrm{E}+00$ \\
\hline TE-134 & $1.66 \mathrm{E}-06$ & $0.00 \mathrm{E}+00$ & $1.66 \mathrm{E}-06$ & $0.00 \mathrm{E}+00$ \\
\hline $\mathrm{I}-122$ & $1.57 \mathrm{E}-11$ & $0.00 \mathrm{E}+00$ & $1.57 \mathrm{E}-11$ & $0.00 \overline{\mathrm{E}}+00$ \\
\hline $\mathrm{I}-123$ & $9.89 \mathrm{E}-06$ & $1.25 \mathrm{E}-08$ & $9.90 \mathrm{E}-06$ & $1.26 \mathrm{E}-03$ \\
\hline $\bar{I}-125$ & $2.09 \mathrm{E}-04$ & $3.15 \mathrm{E}-04$ & $5.24 \mathrm{E}-04$ & $6.01 \mathrm{E}-01$ \\
\hline $1-129$ & $1.91 \mathrm{E}-02$ & $5.70 \mathrm{E}-03$ & $2.48 \mathrm{E}-02$ & $2.30 \mathrm{E}-01$ \\
\hline I-130 & $1.10 \mathrm{E}-04$ & $9.04 \mathrm{E}-08$ & $1.10 \mathrm{E}-04$ & $8.21 \mathrm{E}-04$ \\
\hline $\mid-13 !$ & $4.18 \mathrm{E}-04$ & $1.54 \mathrm{E}-04$ & $5.72 \mathrm{E}-04$ & $2 . \overline{70} \overline{\mathrm{E}}-01$ \\
\hline $1-132$ & $1.24 \mathrm{E}-05$ & $0.00 \mathrm{E}+00$ & $1.24 \mathrm{E}-05$ & $0.00 \mathrm{E}+00$ \\
\hline I-133 & $6.46 \mathrm{E}-05$ & $1.04 \mathrm{E}-06$ & $6.56 \mathrm{E}-05$ & $1.59 \mathrm{E}-02$ \\
\hline I-134 & $2.59 \mathrm{E}-06$ & $0.00 \mathrm{E}+00$ & $2.59 \mathrm{E}-06$ & $0.00 \mathrm{E}+00$ \\
\hline I-135 & $3.56 \mathrm{E}-05$ & $0.00 \mathrm{E}+00$ & $3.56 \mathrm{E}-05$ & $0.00 \mathrm{E}+00$ \\
\hline $\mathrm{XE}-122$ & $8.68 \mathrm{E}-07$ & $0.00 \mathrm{E}+00$ & 8.68E-07 & $0.00 \mathrm{E}+00$ \\
\hline $\mathrm{XE}-123$ & $3.86 \mathrm{E}-06$ & $0.00 \mathrm{E}+00$ & $3.86 \mathrm{E}-06$ & $0.00 \mathrm{E}+00$ \\
\hline $\mathrm{XE}-125$ & $3.13 \mathrm{E}-06$ & $0.00 \mathrm{E}+00$ & $3.13 \mathrm{E}-06$ & $0.00 \mathrm{E}+00$ \\
\hline $\mathrm{XE}-127$ & $3.71 \mathrm{E}-06$ & $0.00 \mathrm{E}+00$ & $3.71 \mathrm{E}-06$ & $0.00 \mathrm{E}+00$ \\
\hline XE-131M & $1.35 \mathrm{E}-07$ & $0.00 \mathrm{E}+00$ & $1.35 \mathrm{E}-07$ & $0.00 \mathrm{E}+00$ \\
\hline $\mathrm{XE}-133$ & $4.90 \mathrm{E}-07$ & $0.00 \mathrm{E}+00$ & $4.90 \mathrm{E}-07$ & $0.00 \mathrm{E}+00$ \\
\hline$\overline{\mathrm{XE}}-133 \mathrm{M}$ & $4.18 \mathrm{E}-07$ & $0.00 \mathrm{E}+00$ & $4.18 \mathrm{E}-07$ & $0.00 \mathrm{E}+00$ \\
\hline $\mathrm{XE}-135$ & $2.82 \mathrm{E}-06$ & $0.00 \mathrm{E}+00$ & $2.82 \mathrm{E}-06$ & $0.00 \mathrm{E}+00$ \\
\hline
\end{tabular}


DOE/RL-2000-34, Rev. 0

$12 / 2000$

\begin{tabular}{|c|c|c|c|c|}
\hline Nuclide & $\begin{array}{l}\text { No Ingestion } \\
(\mathrm{mrem} / \mathrm{yr})\end{array}$ & $\begin{array}{l}\text { Ingestion Only } \\
\text { (mrem/yr) }\end{array}$ & $\begin{array}{c}\text { Total With Ingestion } \\
(\mathrm{mrem} / \mathrm{yr})\end{array}$ & $\begin{array}{c}\text { Percent } \\
\text { Ingestion }\end{array}$ \\
\hline $\mathrm{XE}-135 \mathrm{M}$ & $1.19 \mathrm{E}-07$ & $0.00 \mathrm{E}+00$ & $1.19 \mathrm{E}-07$ & $0.00 \mathrm{E}+00$ \\
\hline $\mathrm{XE}-137$ & $4.59 \mathrm{E}-11$ & $0.00 \mathrm{E}+00$ & $4.59 \mathrm{E}-11$ & $0.00 \mathrm{E}+00$ \\
\hline $\mathrm{XE}-138$ & $2.77 \mathrm{E}-07$ & $0.00 \mathrm{E}+00$ & $2.77 \mathrm{E}-07$ & $0.00 \mathrm{E}+00$ \\
\hline$\overline{\mathrm{CS}-1} \overline{34}$ & $6.85 \mathrm{E}-02$ & $1.68 \mathrm{E}-03$ & $7.02 \mathrm{E}-02$ & $2.39 \mathrm{E}-02$ \\
\hline $\mathrm{CS}-134 \mathrm{M}$ & $7.37 \mathrm{E}-07$ & $0.00 \mathrm{E}+00$ & $7.37 \mathrm{E}-07$ & $0.00 \mathrm{E}+00$ \\
\hline $\mathrm{CS}-1 \overline{35}$ & $9.60 \mathrm{E}-05$ & $2.42 \mathrm{E}-04$ & $3.38 \mathrm{E}-04$ & $7.16 \mathrm{E}-01$ \\
\hline CS-136 & $1.87 \mathrm{E}-03$ & $6.76 \mathrm{E}-05$ & $1.94 \mathrm{E}-03$ & $3.49 \overline{\mathrm{E}-02}$ \\
\hline$C S-137$ & $6.36 E-04$ & $1.45 E-03$ & $2.09 E-03$ & $6.95 E-01$ \\
\hline CS-137+D & $2.10 \mathrm{E}-01$ & $1.45 \mathrm{E}-03$ & $2.11 \mathrm{E}-01$ & $6.87 \mathrm{E}-03$ \\
\hline CS-138 & $3.33 \mathrm{E}-06$ & $0.00 \mathrm{E}+00$ & $3.33 \mathrm{E}-06$ & $0.00 \mathrm{E}+00$ \\
\hline CS-139 & $1.69 \mathrm{E}-08$ & $0.00 \mathrm{E}+00$ & $1.69 \mathrm{E}-08$ & $0.00 \mathrm{E}+00$ \\
\hline $\mathrm{BA}-133$ & $7.27 \mathrm{E}-02$ & $0.00 \mathrm{E}+00$ & $7.27 \mathrm{E}-02$ & $0.00 \mathrm{E}+00$ \\
\hline BA-133M & $1.96 \mathrm{E}-05$ & $5.32 \mathrm{E}-08$ & $1.97 \mathrm{E}-05$ & $2.71 \mathrm{E}-03$ \\
\hline BA-137M & $1.24 \mathrm{E}-12$ & $0.00 \mathrm{E}+00$ & $1.24 \mathrm{E}-12$ & $0 . \overline{00 \mathrm{E}+00}$ \\
\hline BA-139 & $1.37 \mathrm{E}-06$ & $0.00 \mathrm{E}+00$ & $1.37 \mathrm{E}-06$ & $0.00 \mathrm{E}+00$ \\
\hline$B A-140$ & $2.40 E-04$ & $9.47 E-06$ & $2.49 E-04$ & $3.80 E-02$ \\
\hline BA-140+D & $1.88 \mathrm{E}-03$ & $9.47 \overline{\mathrm{E}}-06$ & $1.89 \mathrm{E}-03$ & $5.01 \mathrm{E}-03$ \\
\hline BA-141 & $3.55 \mathrm{E}-07$ & $0.00 \mathrm{E}+00$ & $3.55 \mathrm{E}-07$ & $0.00 \mathrm{E}+00$ \\
\hline$\overline{\mathrm{BA}}-142$ & $7.67 \mathrm{E}-08$ & $0.00 \mathrm{E}+00$ & $7.67 \mathrm{E}-08$ & $0.00 \mathrm{E}+00$ \\
\hline$\overline{\mathrm{LA}-140}$ & $3 . \overline{39 E-04}$ & $0.00 \mathrm{E}+00$ & $3.3 \overline{9 E-04}$ & $0.00 \mathrm{E}+00$ \\
\hline LA-141 & $5.57 \mathrm{E}-07$ & $0.00 \mathrm{E}+00$ & $5.57 \mathrm{E}-07$ & $0.00 \mathrm{E}+00$ \\
\hline $\mathrm{LA}-142$ & $1.62 \mathrm{E}-05$ & $0.00 \mathrm{E}+00$ & $1.62 \mathrm{E}-05$ & $0.00 \mathrm{E}+00$ \\
\hline $\mathrm{CE}-141$ & $3.57 \mathrm{E}-04$ & $5.05 \mathrm{E}-06$ & $3.62 \mathrm{E}-04$ & $1.40 \mathrm{E}-02$ \\
\hline CE-143 & $9.66 \mathrm{E}-05$ & $2.66 \overline{\mathrm{E}}-08$ & $9.66 \mathrm{E}-05$ & $2.75 \mathrm{E}-04$ \\
\hline CE-144 & $8.05 \mathrm{E}-03$ & $6.38 \mathrm{E}-05$ & $8.11 \mathrm{E}-03$ & $7.87 \mathrm{E}-03$ \\
\hline PR-143 & $1.74 \mathrm{E}-04$ & $3.99 \mathrm{E}-06$ & $1.78 \mathrm{E}-04$ & $2.24 \mathrm{E}-02$ \\
\hline PR-144 & $5.68 \mathrm{E}-08$ & $0.00 \mathrm{E}+00$ & $5.68 \mathrm{E}-08$ & $0.00 \mathrm{E}+00$ \\
\hline$\overline{\mathrm{PR}-144 \mathrm{M}}$ & $1.01 \mathrm{E}-09$ & $0.00 \mathrm{E}+00$ & $1.01 \mathrm{E}-09$ & $0.00 \mathrm{E}+00$ \\
\hline ND-147 & $2.40 \mathrm{E}-04$ & $2.85 \mathrm{E}-06$ & $2.43 \mathrm{E}-04$ & $1.17 \mathrm{E}-02$ \\
\hline PM-147 & $7.95 \mathrm{E}-04$ & $5.85 \mathrm{E}-06$ & 8.01E-04 & $7.31 \mathrm{E}-03$ \\
\hline PM-148 & $4.15 \mathrm{E}-04$ & $1.86 \mathrm{E}-06$ & $4.17 \mathrm{E}-04$ & $4.47 \mathrm{E}-03$ \\
\hline PM-148M & $6.11 \mathrm{E}-03$ & $2.93 \mathrm{E}-05$ & $6.14 \mathrm{E}-03$ & $4.77 \mathrm{E}-03$ \\
\hline PM-149 & $6.68 \mathrm{E}-05$ & $5.32 \mathrm{E}-08$ & $6.69 \mathrm{E}-05$ & $7.96 \mathrm{E}-04$ \\
\hline PM-151 & $2.73 \mathrm{E}-05$ & $0.00 \mathrm{E}+00$ & $2.73 \mathrm{E}-05$ & $0.00 \mathrm{E}+00$ \\
\hline SM-147 & $1.53 \mathrm{E}+00$ & $1.06 \mathrm{E}-03$ & $1.53 \mathrm{E}+00$ & $6.95 \mathrm{E}-04$ \\
\hline SM-151 & $6.18 \mathrm{E}-04$ & $2.39 \mathrm{E}-06$ & $6.20 \mathrm{E}-04$ & $3.86 \mathrm{E}-03$ \\
\hline SM-153 & $5.19 \mathrm{E}-05$ & $2.66 \mathrm{E}-08$ & $5.19 \mathrm{E}-05$ & $5.12 \bar{E}-04$ \\
\hline EU-152 & $2.35 \mathrm{E}-01$ & $2.66 \mathrm{E}-05$ & $2.35 \mathrm{E}-01$ & $1.13 \mathrm{E}-04$ \\
\hline EU-152M & $9.04 \mathrm{E}-06$ & $0.00 \mathrm{E}+00$ & $9.04 \mathrm{E}-06$ & $0.00 \mathrm{E}+00$ \\
\hline EU-154 & $1.90 \mathrm{E}-01$ & 5.32E-05 & $1.90 \mathrm{E}-01$ & $2.80 \mathrm{E}-04$ \\
\hline EU-155 & $7.42 \mathrm{E}-03$ & $1.06 \mathrm{E}-05$ & $7.43 \mathrm{E}-03$ & $1.43 \mathrm{E}-03$ \\
\hline EU-156 & $1.46 \mathrm{E}-03$ & $1.12 \mathrm{E}-05$ & $1.47 \mathrm{E}-03$ & $7.59 \mathrm{E}-03$ \\
\hline GD-152(b) & $(\mathrm{Pu}-239)$ & $(\mathrm{Pu}-239)$ & (Pu-239) & \\
\hline TB- 160 & $5.08 \mathrm{E}-03$ & $2.39 \mathrm{E}-05$ & $5.10 \mathrm{E}-03$ & $4.69 \mathrm{E}-03$ \\
\hline $\mathrm{HO}-166$ & $7.22 \mathrm{E}-05$ & $0.00 \mathrm{E}+00$ & $7.22 \mathrm{E}-05$ & $0.00 \mathrm{E}+00$ \\
\hline $\mathrm{HO}-166 \mathrm{M}$ & $7.76 \mathrm{E}-01$ & $0 . \overline{00 \mathrm{E}+00}$ & $7.76 \mathrm{E}-01$ & $0.00 \mathrm{E}+00$ \\
\hline $\mathrm{HF}-181$ & $1.72 \mathrm{E}-03$ & $9.84 \mathrm{E}-06$ & $1.73 \mathrm{E}-03$ & $5.69 \mathrm{E}-03$ \\
\hline
\end{tabular}




\begin{tabular}{|c|c|c|c|c|}
\hline Nuclide & $\begin{array}{c}\text { No Ingestion } \\
\text { (mrem/yr) }\end{array}$ & $\begin{array}{l}\text { Ingestion Only } \\
(\mathrm{mrem} / \mathrm{yr})\end{array}$ & $\begin{array}{l}\text { Total With Ingestion } \\
(\mathrm{mrem} / \mathrm{yr})\end{array}$ & $\begin{array}{l}\text { Percent } \\
\text { Ingestion }\end{array}$ \\
\hline W-181 & $3.27 \mathrm{E}-04$ & $5.80 \mathrm{E}-06$ & $3.33 \mathrm{E}-04$ & $1.74 \mathrm{E}-02$ \\
\hline W-185 & $1.59 \mathrm{E}-05$ & $2.66 \mathrm{E}-05$ & $4.25 \mathrm{E}-05$ & $6.26 \mathrm{E}-01$ \\
\hline W-187 & $4.48 \mathrm{E}-05$ & $2.66 \mathrm{E}-08$ & $4.48 \mathrm{E}-05$ & $5.93 \mathrm{E}-04$ \\
\hline RE-187 & $1.13 \mathrm{E}-06$ & $6.95 \mathrm{E}-07$ & $1.82 \mathrm{E}-06$ & $3.81 \mathrm{E}-01$ \\
\hline IR-192 & $4.42 \mathrm{E}-03$ & $1.49 \mathrm{E}-05$ & $4.43 \mathrm{E}-03$ & $3.36 \mathrm{E}-03$ \\
\hline HG-203 & $8.14 \mathrm{E}-04$ & $1.42 \mathrm{E}-04$ & $9.56 \mathrm{E}-04$ & $1.49 \mathrm{E}-01$ \\
\hline TL-207 & $2.09 \mathrm{E}-11$ & $0.00 \mathrm{E}+\overline{00}$ & $2.09 \mathrm{E}-11$ & $0.00 \mathrm{E}+00$ \\
\hline TL-208 & $7.77 \mathrm{E}-11$ & $0.00 \mathrm{E}+00$ & $7.77 \mathrm{E}-11$ & $0.00 \mathrm{E}+00$ \\
\hline TL-209 & $4.94 \mathrm{E}-13$ & $0.00 \mathrm{E}+00$ & $4.94 \mathrm{E}-13$ & $0.00 \mathrm{E}+00$ \\
\hline PB-209 & $1.17 \mathrm{E}-06$ & $0.00 \mathrm{E}+00$ & $1.17 \mathrm{E}-06$ & $0.00 \mathrm{E}+00$ \\
\hline$P B-210$ & $2.86 E-0 I$ & $2.02 E-02$ & $3.06 E-0 I$ & $6.60 E-02$ \\
\hline PB-210+D & $2.86 \mathrm{E}-01$ & $2.02 \mathrm{E}-02$ & $3.06 \mathrm{E}-01$ & $6.61 \mathrm{E}-02$ \\
\hline PB-211 & $2.20 \mathrm{E}-05$ & $0.00 \mathrm{E}+00$ & $2.20 \mathrm{E}-05$ & $0.00 \mathrm{E}+00$ \\
\hline PB-212 & $2.89 \mathrm{E}-03$ & $0.00 E+00$ & $2.89 \mathrm{E}-03$ & $0.00 \mathrm{E}+00$ \\
\hline PB-214 & $1.54 \mathrm{E}-06$ & $0.00 \mathrm{E}+00$ & $1.54 \mathrm{E}-06$ & $0.00 \mathrm{E}+00$ \\
\hline BI-210 & $3.96 \mathrm{E}-03$ & $0.00 \mathrm{E}+00$ & $3.96 \mathrm{E}-03$ & $0.00 \mathrm{E}+00$ \\
\hline BI-211 & $2.53 \mathrm{E}-13$ & $0.00 \mathrm{E}+00$ & $2.53 \mathrm{E}-13$ & $0.00 \mathrm{E}+00$ \\
\hline$\overline{\mathrm{BI}}-212$ & $1.54 \mathrm{E}-04$ & $0.00 \mathrm{E}+00$ & $1.54 \mathrm{E}-04$ & $0.00 \mathrm{E}+00$ \\
\hline $\mathrm{BI}-213$ & $4.28 \mathrm{E}-06$ & $0.00 \mathrm{E}+00$ & $4.28 \mathrm{E}-06$ & $0.00 \mathrm{E}+00$ \\
\hline BI-214 & $1.08 \mathrm{E}-06$ & $0.00 \mathrm{E}+00$ & $1.08 \mathrm{E}-06$ & $0.00 \mathrm{E}+00$ \\
\hline PO-210 & $1.79 \mathrm{E}-01$ & $5.80 \mathrm{E}-03$ & $1.85 \mathrm{E}-01$ & $3.14 \mathrm{E}-02$ \\
\hline $\mathrm{PO}-212$ (c) & $0.00 \mathrm{E}+00$ & $0.00 \mathrm{E}+00$ & $0.00 \mathrm{E}+00$ & \\
\hline $\mathrm{PO}-213$ (c) & $0.00 \mathrm{E}+00$ & $0.00 \mathrm{E}+00$ & $0.00 \mathrm{E}+00$ & \\
\hline $\mathrm{PO}-214$ (c) & $0.00 \mathrm{E}+00$ & $0.00 \mathrm{E}+00$ & $0.00 \mathrm{E}+00$ & \\
\hline PO-215 (c) & $0.00 \mathrm{E}+00$ & $0.00 \mathrm{E}+00$ & $0.00 \mathrm{E}+00$ & \\
\hline $\mathrm{PO}-216(\mathrm{c})$ & $0.00 \mathrm{E}+00$ & $0.00 \mathrm{E}+00$ & $0.00 \mathrm{E}+00$ & \\
\hline PO-218 & $1.78 \mathrm{E}-12$ & $0.00 \mathrm{E}+00$ & $1.78 \mathrm{E}-12$ & $0.00 \mathrm{E}+00$ \\
\hline AT-217 (c) & $0.00 \mathrm{E}+00$ & $0.00 \mathrm{E}+00$ & $0.00 \mathrm{E}+00$ & \\
\hline $\mathrm{RN}-219(\mathrm{e})$ & $5.15 \mathrm{E}-04$ & $3.64 \mathrm{E}-05$ & $5.51 \mathrm{E}-04$ & $6.61 E-02$ \\
\hline RN-220(e) & $4.05 \mathrm{E}-06$ & $0.00 \mathrm{E}+00$ & $4.05 \mathrm{E}-06$ & $0.00 \mathrm{E}+00$ \\
\hline RN-222 & $5.95 \mathrm{E}-05$ & $0.00 \mathrm{E}+00$ & $5.95 \mathrm{E}-05$ & $0.00 \mathrm{E}+00$ \\
\hline FR-221 & $1.00 \mathrm{E}-08$ & $0.00 \mathrm{E}+00$ & $1.00 \mathrm{E}-08$ & $0.00 \mathrm{E}+00$ \\
\hline FR-223 & $2.57 \mathrm{E}-06$ & $0.00 \mathrm{E}+00$ & $2.57 \mathrm{E}-06$ & $0.00 \mathrm{E}+00$ \\
\hline RA-223 & $1.70 \mathrm{E}-01$ & $6.91 \mathrm{E}-04$ & $1.71 \mathrm{E}-01$ & $4.05 \mathrm{E}-03$ \\
\hline RA-224 & $7.09 \mathrm{E}-02$ & $5.32 \mathrm{E}-05$ & $7.10 \mathrm{E}-02$ & $7.50 \mathrm{E}-04$ \\
\hline RA-225 & $8.59 \mathrm{E}-02$ & $7.45 \mathrm{E}-04$ & 8.66E-02 & $8.59 \mathrm{E}-03$ \\
\hline RA-226 & $1.85 \mathrm{E}-01$ & $5.11 \mathrm{E}-03$ & $1.90 \mathrm{E}-01$ & $2.69 \mathrm{E}-02$ \\
\hline RA-228 & $5.00 \mathrm{E}-02$ & $2.61 \mathrm{E}-03$ & $5.26 \mathrm{E}-02$ & $4.95 \mathrm{E}-02$ \\
\hline $\mathrm{AC}-225$ & $1.25 \mathrm{E}-01$ & $5.32 \mathrm{E}-05$ & $1.25 \mathrm{E}-01$ & $4.25 \mathrm{E}-04$ \\
\hline $\mathrm{AC}-227$ & $1.31 \mathrm{E}+01$ & $1.06 \mathrm{E}-02$ & $1.31 \mathrm{E}+01$ & $8.11 \mathrm{E}-04$ \\
\hline AC-228 & $1.31 \mathrm{E}-03$ & $0.00 \mathrm{E}+00$ & $1.31 \mathrm{E}-03$ & $0.00 \mathrm{E}+00$ \\
\hline TH-227 & $2.41 \mathrm{E}-01$ & $2.66 \mathrm{E}-05$ & $2.41 \mathrm{E}-01$ & $1.10 \mathrm{E}-04$ \\
\hline TH-228 & $5.19 \mathrm{E}+00$ & $0.00 \mathrm{E}+00$ & $5.19 \mathrm{E}+00$ & $0.00 \mathrm{E}+00$ \\
\hline TH-229 & $1.44 \mathrm{E}+01$ & $2.66 \mathrm{E}-03$ & $1.44 \mathrm{E}+01$ & $1.85 \mathrm{E}-04$ \\
\hline TH-230 & $5.13 \mathrm{E}+00$ & $2.66 \mathrm{E}-03$ & $5.13 \mathrm{E}+00$ & $5.18 \mathrm{E}-04$ \\
\hline TH-231 & $1.98 \mathrm{E}-05$ & $0.00 \mathrm{E}+00$ & $1.98 \mathrm{E}-05$ & $0.00 \mathrm{E}+00$ \\
\hline TH-232 & $7.39 E+00$ & $0.00 E+00$ & $7.39 E+00$ & $0.00 E+00$ \\
\hline
\end{tabular}


1

2

3

4

5
ATTACHMENT 2

CAP88-PC SYNOPSIS REPORT (1 OF 10) 
DOE/RL-2000-34, Rev. 0

$12 / 2000$

1

2

3

4

5

This page intentionally left blank. 
C A P 88 - P C

Version 1.00

Clean Air Act Assessment Package - 1988

SYNOPSIS REPORT

Non-Radon Individual Assessment

May 9, $2000 \quad 10: 36$ am

Facility: 200W REDOX 40m eff DATASET1

Address: BATTELLE PNL

POB 999

City: RICHLAND

State: WA Zip: 99352

Effective Dose Equivalent

(mrem/year)

$4.56 \mathrm{E}-01$

At This Location: 18310 Meters East Southeast

Source Category: 40.0 M STACK UNIT CI AIRBORNE RELEASE

Source Type: Stack

Emission Year:

Comments: worker set 1 (of 10) use defaultp.han

Dataset Name: w $2 \mathrm{w} 40 \mathrm{~m}$ set 1

Dataset Date: May 9, 2000 10:26 am

Wind File: WNDFILES $\backslash H S 200$ W10.WND

C A U T I O N: Defaults Have Been Changed

(Changes Detailed on Next Page) 


\section{CAUTION!}

The Following DEFAULT VALUES Have Been Changed By The User.

\section{These changes CANNOT BE USED to demonstrate compliance} per 40 CFR 61.93(a) unless specifically approved by EPA.

Inhalation Rate of Man

Changed From: $9.1670 \mathrm{E}+05$

To: $9.7000 \mathrm{E}+05$

Fraction Radioactivity on Veg. \& Prod. after Washing

Changed From: 0.5000

To: 1.000

Ingestion Rate of Meat by Man

Changed From: 85.00

To: 98.00

Ingestion Rate of Leafy Veg. by Man

Changed From: 18.00

To: 30.00

Ingestion Rate of Milk by Man

Changed From: 112.0

To: 270.0

Ingestion Rate of Produce by Man

Changed From: 176.0

To: 220.0

Fraction Time Spent Swimming

Changed From: 0.0000

To: $1.0000 \mathrm{E}-02$

Fraction Year Animals Graze on Pasture

Changed From: 0.4000

To: 0.7500

Fraction Year Animals Graze on Pasture

Changed From: 0.4300

To: 1.0000

The Following DEFAULT VALUES Have Been Changed By The User

(Continued): 
Removal Rate Constant - Physical Loss by Weathering

Changed From: $2.9000 \mathrm{E}-03$

To: $3.0000 \mathrm{E}-03$

Effec. Surface Density of Soil, Dry Weight

Changed From: 215.0

To: 224.0

Fallout interception Fraction-Pasture

Changed From: 0.5700

To: 0.2500

Fallout Interception Fraction-Vegetable

Changed From: 0.2000

To: 0.2500

Period Exposure - Growing Season - Crops/Leafy Veg.

Changed From: 1440.

To: 2160 .

Time Delay - Ingestion Stored Feed

Changed From: 2160.

To: 2400 .

Time Delay - Ingestion Leafy Veg. - Man

Changed From: 336.0 .

To: 24.00

Time Delay - Ingestion Produce - Man

Changed From: 336.0 .

To: 120.0

Avg. Time - Slaughter to Consumption

Changed From: 20.00

To: 34.00 
The Following DEFAULT VALUES Have Been Changed By The User (Continued):

Agr. Productivity by Unit Area - Milk

Changed From: 0.2800

To: 0.3000

Agr. Productivity by Unit Area - Prod/Leafy Veg.

Changed From: 0.7160

To: 2.000

Period Long-term Buildup in Soil

Changed From: 100.0

To: 50.00

Direction Single Location - Individual Calculation

Changed From: 0

To: 12

Direction Single Location - Individual Calculation

Changed From: 0

To: 1

Ground Surface Correction Factor

Changed From: 0.5000

To: 1.000 
May $9,2000 \quad 10: 36$ am SYNOPSIS

Page 1

(w 2 w 40m set l)

MAXIMALLY EXPOSED INDIVIDUAL

Location Of The Individual: 18310 Meters East Southeast

Lifetime Fatal Cancer Risk: 1.12E-05

ORGAN DOSE EQUIVALENT SUMMARY

Dose

Equivalent

Organ

$(\mathrm{mrem} / \mathrm{y})$ )

GONADS

$5.28 \mathrm{E}-01$

BREAST

$4.80 \mathrm{E}-01$

R MAR

4.07E-01

LUNGS

4.37E-01

THYROID

$5.01 \mathrm{E}-01$

ENDOST

4.36E-01

RMNDR

4.09E-01

EFFEC

4.56E-01 
May $9,2000 \quad 10: 36$ am

SYNOPSIS

Page 2

(w 2w 40m set1)

RADIONUCLIDE EMISSIONS DURING THE YEAR

Nuclide

\begin{tabular}{|c|c|c|c|}
\hline \multicolumn{4}{|c|}{ Source } \\
\hline \multirow{2}{*}{$\begin{array}{c}\# 1 \\
\text { Class }\end{array}$} & TOTAL & \multirow[b]{2}{*}{$\mathrm{Ci} / \mathrm{y}$} & \multirow[b]{2}{*}{$\mathrm{Ci} / \mathrm{y}$} \\
\hline & Size & & \\
\hline * & 0.00 & $1.0 \mathrm{E}+00$ & $1.0 \mathrm{E}+00$ \\
\hline \multirow[t]{2}{*}{$Y$} & 1.00 & $1.0 \mathrm{E}+00$ & $1.0 \mathrm{E}+00$ \\
\hline & 0.00 & $1.0 \mathrm{E}+00$ & $1.0 \mathrm{E}+00$ \\
\hline D & 1.00 & $1.0 \mathrm{E}+00$ & $1.0 \mathrm{E}+00$ \\
\hline$*$ & 0.00 & $1.0 \mathrm{E}+00$ & $1.0 \mathrm{E}+00$ \\
\hline D & 1.00 & $1.0 \mathrm{E}+00$ & $1.0 \mathrm{E}+00$ \\
\hline D & 1.00 & $1.0 \mathrm{E}+00$ & $1.0 \mathrm{E}+00$ \\
\hline D & 1.00 & $1.0 \mathrm{E}+00$ & $1.0 \mathrm{E}+00$ \\
\hline $\mathrm{D}$ & 1.00 & $1.0 \mathrm{E}+00$ & $1.0 \mathrm{E}+00$ \\
\hline D & 1.00 & $1.0 \mathrm{E}+00$ & $1.0 \mathrm{E}+00$ \\
\hline D & 1.00 & $1.0 \mathrm{E}+00$ & $1.0 \mathrm{E}+00$ \\
\hline D & 1.00 & $1.0 \mathrm{E}+00$ & $1.0 \mathrm{E}+00$ \\
\hline D & 1.00 & $1.0 \mathrm{E}+00$ & $1.0 \mathrm{E}+00$ \\
\hline$*$ & 0.00 & $1.0 \mathrm{E}+00$ & $1.0 \mathrm{E}+00$ \\
\hline \multirow[t]{2}{*}{$\mathrm{D}$} & 1.00 & $1.0 \mathrm{E}+00$ & $1.0 \mathrm{E}+00$ \\
\hline & 0.00 & $1.0 \mathrm{E}+00$ & $1.0 \mathrm{E}+00$ \\
\hline Y & 1.00 & $1.0 \mathrm{E}+00$ & $1.0 \mathrm{E}+00$ \\
\hline Y & 1.00 & $1.0 \mathrm{E}+00$ & $1.0 \mathrm{E}+00$ \\
\hline W & 1.00 & $1.0 \mathrm{E}+00$ & $1.0 \mathrm{E}+00$ \\
\hline W & 1.00 & $1.0 \mathrm{E}+00$ & $1.0 \mathrm{E}+00$ \\
\hline W & 1.00 & $1.0 \mathrm{E}+00$ & $1.0 \mathrm{E}+00$ \\
\hline W & 1.00 & $1.0 \mathrm{E}+00$ & $1.0 \mathrm{E}+00$ \\
\hline Y & 1.00 & $1.0 \mathrm{E}+00$ & $1.0 \mathrm{E}+00$ \\
\hline$Y$ & 1.00 & $1.0 \mathrm{E}+00$ & $1.0 \mathrm{E}+00$ \\
\hline Y & 1.00 & $1.0 \mathrm{E}+00$ & $1.0 \mathrm{E}+00$ \\
\hline W & 1.00 & $1.0 \mathrm{E}+00$ & $1.0 \mathrm{E}+00$ \\
\hline W & 1.00 & $1.0 \mathrm{E}+00$ & $1.0 \mathrm{E}+00$ \\
\hline W & 1.00 & $1.0 \mathrm{E}+00$ & $1.0 \mathrm{E}+00$ \\
\hline$Y$ & 1.00 & $1.0 \mathrm{E}+00$ & $1.0 \mathrm{E}+00$ \\
\hline$Y$ & 1.00 & $1.0 \mathrm{E}+00$ & $1.0 \mathrm{E}+00$ \\
\hline Y & 1.00 & $1.0 \mathrm{E}+00$ & $1.0 \mathrm{E}+00$ \\
\hline$Y$ & 1.00 & $1.0 \mathrm{E}+00$ & $1.0 \mathrm{E}+00$ \\
\hline
\end{tabular}

\section{SITE INFORMATION}

Temperature: 12 degrees $\mathrm{C}$ Precipitation: $\quad 16 \mathrm{~cm} / \mathrm{y}$ Mixing Height: $1000 \mathrm{~m}$ 
May 9, $2000 \quad 10: 36$ am

SYNOPSIS

Page 2

(w 2w 40m set2)

RADIONUCLIDE EMISSIONS DURING THE YEAR

Nuclide

GA-67

AS-76

SE-79

BR-82

BR-83

BR-84

BR-85

KR-83M

KR-85

KR-87

KR-88

KR-89

$\mathrm{Kr}-90$

RB-86

RB-87

RB-88

RB-89

RB-90

RB-90M

SR-89

SR-90

SR-91

SR-92

Y-90

$\mathrm{Y}-90 \mathrm{M}$

$\mathrm{Y}-91$

$\mathrm{Y}-91 \mathrm{M}$

$\mathrm{Y}-92$

Y-93

ZR-93

ZR-95
Source

\begin{tabular}{|c|c|c|c|}
\hline & ource & & \\
\hline$\# 1$ & TOTAL & & \\
\hline Class & Size & $\mathrm{Ci} / \mathrm{y}$ & $\mathrm{Ci} / \mathrm{y}$ \\
\hline W & 1.00 & $1.0 \mathrm{E}+00$ & $1.0 \mathrm{E}+00$ \\
\hline W & 1.00 & $1.0 \mathrm{E}+00$ & $1.0 \mathrm{E}+00$ \\
\hline & 0.00 & $1.0 \mathrm{E}+00$ & $1.0 \mathrm{E}+00$ \\
\hline D & 1.00 & $1.0 \mathrm{E}+00$ & $1.0 \mathrm{E}+00$ \\
\hline & 0.00 & $1.0 \mathrm{E}+00$ & $1.0 \mathrm{E}+00$ \\
\hline & 0.00 & $1.0 \mathrm{E}+00$ & $1.0 \mathrm{E}+00$ \\
\hline & 0.00 & $1.0 \mathrm{E}+00$ & $1.0 \mathrm{E}+00$ \\
\hline * & 0.00 & $1.0 \mathrm{E}+00$ & $1.0 \mathrm{E}+00$ \\
\hline * & 0.00 & $1.0 \mathrm{E}+00$ & $1.0 \mathrm{E}+00$ \\
\hline * & 0.00 & $1.0 \mathrm{E}+00$ & $1.0 \mathrm{E}+00$ \\
\hline * & 0.00 & $1.0 \mathrm{E}+00$ & $1.0 \mathrm{E}+00$ \\
\hline$*$ & 0.00 & $1.0 \mathrm{E}+00$ & $1.0 \mathrm{E}+00$ \\
\hline$*$ & 0.00 & $1.0 \mathrm{E}+00$ & $1.0 \mathrm{E}+00$ \\
\hline D & 1.00 & $1.0 \mathrm{E}+00$ & $1.0 \mathrm{E}+00$ \\
\hline D & 1.00 & $1.0 \mathrm{E}+00$ & $1.0 \mathrm{E}+00$ \\
\hline D & 1.00 & $1.0 \mathrm{E}+00$ & $1.0 \mathrm{E}+00$ \\
\hline D & 1.00 & $1.0 \mathrm{E}+00$ & $1.0 \mathrm{E}+00$ \\
\hline & 0.00 & $1.0 \mathrm{E}+00$ & $1.0 \mathrm{E}+00$ \\
\hline & 0.00 & $1.0 \mathrm{E}+00$ & $1.0 \mathrm{E}+00$ \\
\hline D & 1.00 & $1.0 \mathrm{E}+00$ & $1.0 \mathrm{E}+00$ \\
\hline D & 1.00 & $1.0 \mathrm{E}+00$ & $1.0 \mathrm{E}+00$ \\
\hline D & 1.00 & $1.0 \mathrm{E}+00$ & $1.0 \mathrm{E}+00$ \\
\hline D & 1.00 & $1.0 \mathrm{E}+00$ & $1.0 \mathrm{E}+00$ \\
\hline$Y$ & 1.00 & $1.0 \mathrm{E}+00$ & $1.0 \mathrm{E}+00$ \\
\hline & 0.00 & $1.0 \mathrm{E}+00$ & $1.0 \mathrm{E}+00$ \\
\hline$Y$ & 1.00 & $1.0 \mathrm{E}+00$ & $1.0 \mathrm{E}+00$ \\
\hline$Y$ & 1.00 & $1.0 \mathrm{E}+00$ & $1.0 \mathrm{E}+00$ \\
\hline$Y$ & 1.00 & $1.0 \mathrm{E}+00$ & $1.0 \mathrm{E}+00$ \\
\hline Y & 1.00 & $1.0 \mathrm{E}+00$ & $1.0 \mathrm{E}+00$ \\
\hline W & 1.00 & $1.0 \mathrm{E}+00$ & $1.0 \mathrm{E}+00$ \\
\hline W & 1.00 & $1.0 \mathrm{E}+00$ & $1.0 \mathrm{E}+00$ \\
\hline
\end{tabular}

\section{SITE INFORMATION}

Temperature: 12 degrees $\mathrm{C}$ Precipitation: $\quad 16 \mathrm{~cm} / \mathrm{y}$ Mixing Height: $1000 \mathrm{~m}$ 
May 9,2000 10:37 am

Page 2

SYNOPSIS

(w 2w 40m set3)

RADIONUCLIDE EMISSIONS DURING THE YEAR

Nuclide

\begin{tabular}{l}
\hline NB-93M \\
NB-94 \\
NB-95 \\
NB-95M \\
NB-97 \\
NB-97M \\
MO-93 \\
MO-99 \\
TC-99M \\
TC-97 \\
TC-99 \\
TC-101 \\
RU-97 \\
RU-103 \\
RU-105 \\
RU-106 \\
RH-105 \\
RH-105M \\
RH-106 \\
PD-107 \\
PD-109 \\
AG-109M \\
AG-110 \\
AG-110M \\
AG-111 \\
CD-113 \\
CD-113M \\
CD-115 \\
CD-115M \\
IN-113M \\
IN-115 \\
IN-115M
\end{tabular}

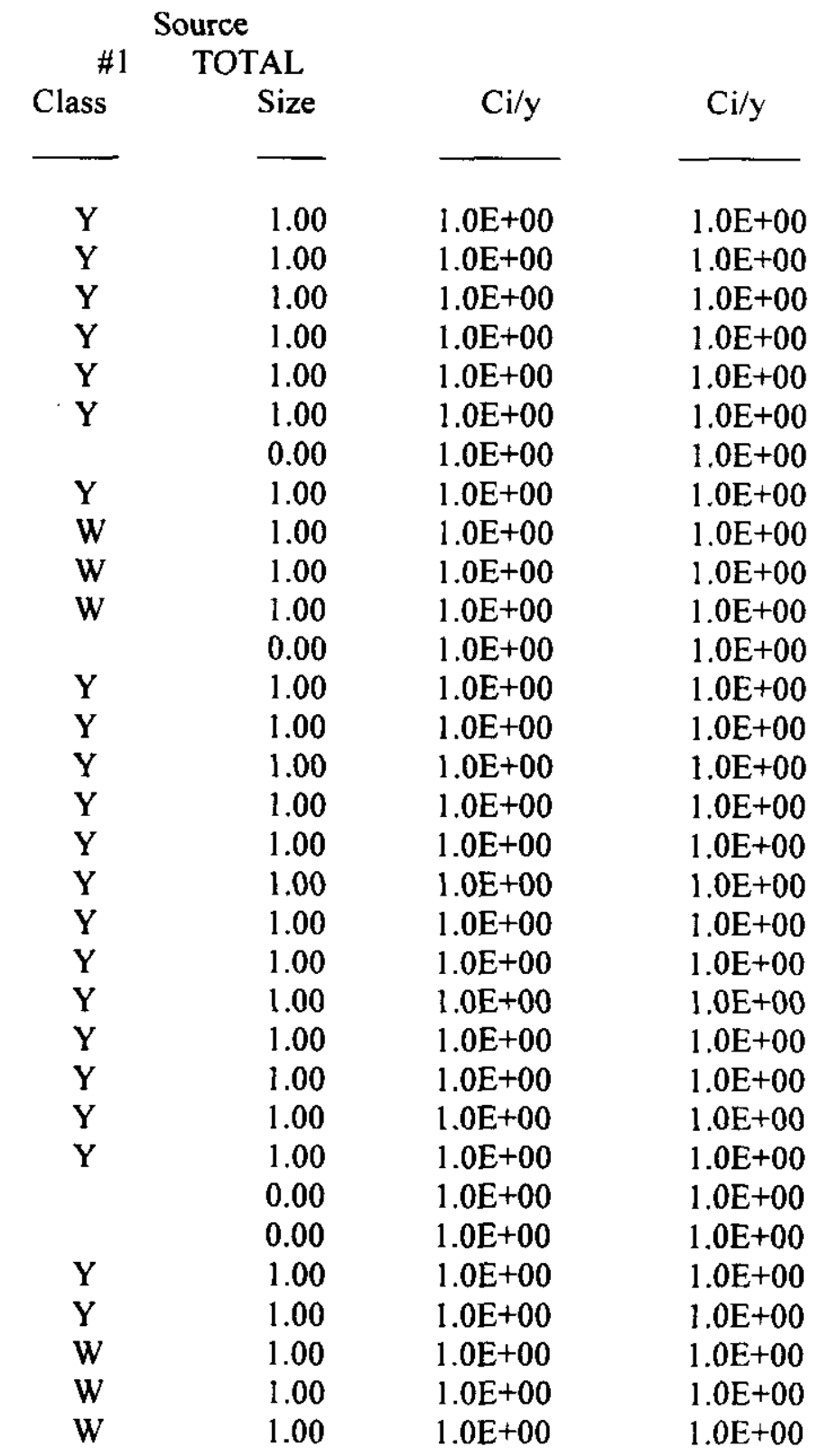

\section{SITE INFORMATION}

Temperature: 12 degrees $\mathrm{C}$ Precipitation: $\quad 16 \mathrm{~cm} / \mathrm{y}$ Mixing Height: $1000 \mathrm{~m}$ 
May 9,2000 10:37 am

SYNOPSIS

Page 2

(w 2w 40m set4)

RADIONUCLIDE EMISSIONS DURING THE YEAR

Nuclide

$\mathrm{SN}-113$

$\mathrm{SN}-125$

$\mathrm{SN}-126$

SB-124

SB-125

SB-126

SB-126M

SB-127

TE-125M

TE-127

TE-127M

TE-129

TE-129M

TE-131

TE-131M

TE-132

TE-133

TE-133M

TE-134

I- 122

I-123

I- 125

I-129

I- 130

I-131

I- 132

I- 133

I-134

I-135
Source

\#1 TOTAL

Class

Size

W

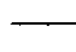

1.00

0.00

1.00

1.00

1.00

1.00

1.00

1.00

1.00

1.00

1.00

1.00

1.00

1.00

1.00

1.00

0.00

0.00

0.00

1.00

1.00

1.00

1.00

1.00

1.00

1.00

1.00

1.00

1.00

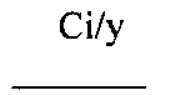

$1.0 \mathrm{E}+00$

$1.0 \mathrm{E}+00$

$1.0 \mathrm{E}+00$

$1.0 \mathrm{E}+00$

$1.0 \mathrm{E}+00$

$1.0 \mathrm{E}+00$

$1.0 \mathrm{E}+00$

$1.0 \mathrm{E}+00$

$1.0 \mathrm{E}+00$

$1.0 \mathrm{E}+00$

$1.0 \mathrm{E}+00$

$1.0 \mathrm{E}+00$

$1.0 \mathrm{E}+00$

$1.0 \mathrm{E}+00$

$1.0 \mathrm{E}+00$

$1.0 \mathrm{E}+00$

$1.0 \mathrm{E}+00$

$1.0 \mathrm{E}+00$

$1.0 \mathrm{E}+00$

$1.0 \mathrm{E}+00$

$1.0 \mathrm{E}+00$

$1.0 \mathrm{E}+00$

$1.0 \mathrm{E}+00$

$1.0 \mathrm{E}+00$

$1.0 \mathrm{E}+00$

$1.0 \mathrm{E}+00$

$1.0 \mathrm{E}+00$

$1.0 \mathrm{E}+00$

$1.0 \mathrm{E}+00$
$\mathrm{Ci} / \mathrm{y}$

$1.0 \mathrm{E}+00$

$1.0 \mathrm{E}+00$

$1.0 \mathrm{E}+00$

$1.0 \mathrm{E}+00$

$1.0 \mathrm{E}+00$

$1.0 \mathrm{E}+00$

$1.0 \mathrm{E}+00$

$1.0 \mathrm{E}+00$

$1.0 \mathrm{E}+00$

$1.0 \mathrm{E}+00$

$1.0 \mathrm{E}+00$

$1.0 \mathrm{E}+00$

$1.0 \mathrm{E}+00$

$1.0 \mathrm{E}+00$

$1.0 \mathrm{E}+00$

$1.0 \mathrm{E}+00$

$1.0 \mathrm{E}+00$

$1.0 \mathrm{E}+00$

$1.0 \mathrm{E}+00$

$1.0 \mathrm{E}+00$

$1.0 \mathrm{E}+00$

$1.0 \mathrm{E}+00$

$1.0 \mathrm{E}+00$

$1.0 \mathrm{E}+00$

$1.0 \mathrm{E}+00$

$1.0 \mathrm{E}+00$

$1.0 \mathrm{E}+00$

$1.0 \mathrm{E}+00$

$1.0 \mathrm{E}+00$

\section{SITE INFORMATION}

Temperature: 12 degrees $\mathrm{C}$ Precipitation: $\quad 16 \mathrm{~cm} / \mathrm{y}$ Mixing Height: $1000 \mathrm{~m}$ 
Page 2

(w 2w 40m set5)

\section{RADIONUCLIDE EMISSIONS DURING THE YEAR}

\begin{tabular}{l} 
Nuclide \\
\hline XE-122 \\
XE-123 \\
XE-125 \\
XE-127 \\
XE-131M \\
XE-133 \\
XE-133M \\
XE-135 \\
XE-135M \\
XE-137 \\
XE-138 \\
CS-134 \\
CS-134M \\
CS-135 \\
CS-136 \\
CS-137 \\
BA-137M \\
CS-138 \\
CS-139 \\
BA-133 \\
BA-133M \\
BA-137M \\
BA-139 \\
BA-140 \\
LA-140 \\
BA-141 \\
BA-142 \\
LA-140 \\
LA-141 \\
LA-142 \\
CE-141 \\
CE-143 \\
CE-144 \\
PR-143 \\
PR-144 \\
PR-144M
\end{tabular}

\begin{tabular}{|c|c|c|c|}
\hline \multicolumn{4}{|c|}{ Source } \\
\hline \multirow{2}{*}{$\begin{array}{c}\# 1 \\
\text { Class }\end{array}$} & TOTAL & \multirow[b]{2}{*}{$\mathrm{Ci} / \mathrm{y}$} & \multirow[b]{2}{*}{$\mathrm{Ci} / \mathrm{y}$} \\
\hline & Size & & \\
\hline$*$ & 0.00 & $1.0 \mathrm{E}+00$ & $1.0 \mathrm{E}+00$ \\
\hline - & 0.00 & $1.0 \mathrm{E}+00$ & $1.0 \mathrm{E}+00$ \\
\hline * & 0.00 & $1.0 \mathrm{E}+00$ & $1.0 \mathrm{E}+00$ \\
\hline * & 0.00 & $1.0 \mathrm{E}+00$ & $1.0 \mathrm{E}+00$ \\
\hline * & 0.00 & $1.0 \mathrm{E}+00$ & $1.0 \mathrm{E}+00$ \\
\hline * & 0.00 & $1.0 \mathrm{E}+00$ & $1.0 \mathrm{E}+00$ \\
\hline * & 0.00 & $1.0 \mathrm{E}+00$ & $1.0 \mathrm{E}+00$ \\
\hline * & 0.00 & $1.0 \mathrm{E}+00$ & $1.0 \mathrm{E}+00$ \\
\hline * & 0.00 & $1.0 \mathrm{E}+00$ & $1.0 \mathrm{E}+00$ \\
\hline * & 0.00 & $1.0 \mathrm{E}+00$ & $1.0 \mathrm{E}+00$ \\
\hline * & 0.00 & $1.0 \mathrm{E}+00$ & $1.0 \mathrm{E}+00$ \\
\hline D & 1.00 & $1.0 \mathrm{E}+00$ & $1.0 \mathrm{E}+00$ \\
\hline D & 1.00 & $1.0 \mathrm{E}+00$ & $1.0 \mathrm{E}+00$ \\
\hline D & 1.00 & $1.0 \mathrm{E}+00$ & $1.0 \mathrm{E}+00$ \\
\hline D & 1.00 & $1.0 \mathrm{E}+00$ & $1.0 \mathrm{E}+00$ \\
\hline D & 1.00 & $1.0 \mathrm{E}+00$ & $1.0 \mathrm{E}+00$ \\
\hline D & 1.00 & $0.0 \mathrm{E}+00$ & $0.0 \mathrm{E}+00$ \\
\hline \multirow{2}{*}{$\mathrm{D}$} & 1.00 & $1.0 \mathrm{E}+00$ & $1.0 \mathrm{E}+00$ \\
\hline & 0.00 & $1.0 \mathrm{E}+00$ & $1.0 \mathrm{E}+00$ \\
\hline D & 1.00 & $1.0 \mathrm{E}+00$ & $1.0 \mathrm{E}+00$ \\
\hline D & 1.00 & $1.0 \mathrm{E}+00$ & $1.0 \mathrm{E}+00$ \\
\hline D & 1.00 & $1.0 \mathrm{E}+00$ & $1.0 \mathrm{E}+00$ \\
\hline D & 1.00 & $1.0 \mathrm{E}+00$ & $1.0 \mathrm{E}+00$ \\
\hline D & 1.00 & $1.0 \mathrm{E}+00$ & $1.0 \mathrm{E}+00$ \\
\hline \multirow[t]{3}{*}{ W } & 1.00 & $0.0 \mathrm{E}+00$ & $0.0 \mathrm{E}+00$ \\
\hline & 0.00 & $1.0 \mathrm{E}+00$ & $1.0 \mathrm{E}+00$ \\
\hline & 0.00 & $1.0 \mathrm{E}+00$ & $1.0 \mathrm{E}+00$ \\
\hline \multirow[t]{3}{*}{ W } & 1.00 & $1.0 \mathrm{E}+00$ & $1.0 \mathrm{E}+00$ \\
\hline & 0.00 & $1.0 \mathrm{E}+00$ & $1.0 \mathrm{E}+00$ \\
\hline & 0.00 & $1.0 \mathrm{E}+00$ & $1.0 \mathrm{E}+00$ \\
\hline $\mathrm{Y}$ & 1.00 & $1.0 \mathrm{E}+00$ & $1.0 \mathrm{E}+00$ \\
\hline $\mathrm{Y}$ & 1.00 & $1.0 \mathrm{E}+00$ & $1.0 \mathrm{E}+00$ \\
\hline $\mathrm{Y}$ & 1.00 & $1.0 \mathrm{E}+00$ & $1.0 \mathrm{E}+00$ \\
\hline Y & 1.00 & $1.0 \mathrm{E}+00$ & $1.0 \mathrm{E}+00$ \\
\hline Y & 1.00 & $1.0 \mathrm{E}+00$ & $1.0 \mathrm{E}+00$ \\
\hline $\mathrm{Y}$ & 1.00 & $1.0 \mathrm{E}+00$ & $1.0 \mathrm{E}+00$ \\
\hline
\end{tabular}

\section{SITE INFORMATION}

Temperature: 12 degrees $\mathrm{C}$

Precipitation: $16 \mathrm{~cm} / \mathrm{y}$

Mixing Height: $1000 \mathrm{~m}$ 
May 9,2000 10:37 am

SYNOPSIS

Page 2

(w 2w 40m set6)

RADIONUCLIDE EMISSIONS DURING THE YEAR

Nuclide

ND-147

PM-147

PM-148

PM-148M

PM-149

PM-151

SM-147

SM-151

SM-153

EU-152

EU-152M

EU-154

EU-155

EU-156

GD-152

TB- 160

HO-166

HO-166M

HF-181

W-181

W-185

W-187
\#1 $\begin{aligned} & \text { Source } \\ & \text { TOTAL }\end{aligned}$

$\begin{array}{lrrr}\text { Class } & \text { Size } & \mathrm{Ci} / \mathbf{y} & \mathrm{Ci} / \mathrm{y} \\ - & - & \end{array}$

$\mathrm{Y} \quad 1.00$

$\begin{array}{ll}\mathrm{Y} & 1.00\end{array}$

$\begin{array}{ll}\mathrm{Y} & 1.00\end{array}$

$\begin{array}{ll}\mathrm{Y} & 1.00\end{array}$

$\begin{array}{ll}Y & 1.00\end{array}$

0.00

1.00

1.00

1.00

1.00

0.00

1.00

1.00

1.00

0.00

1.00

1.00

0.00

1.00

1.00

1.00

1.00

$1.0 \mathrm{E}+00$

$1.0 \mathrm{E}+00$

$1.0 \mathrm{E}+00$

$1.0 \mathrm{E}+00$

$1.0 \mathrm{E}+00$

$1.0 \mathrm{E}+00$

$1.0 \mathrm{E}+00$

$1.0 \mathrm{E}+00$

$1.0 \mathrm{E}+00$

$1.0 \mathrm{E}+00$

$1.0 \mathrm{E}+00$

$1.0 \mathrm{E}+00$

$1.0 \mathrm{E}+00$

$1.0 \mathrm{E}+00$

$1.0 \mathrm{E}+00$

$1.0 \mathrm{E}+00$

$1.0 \mathrm{E}+00$

$1.0 \mathrm{E}+00$

$1.0 \mathrm{E}+00$

$1.0 \mathrm{E}+00$

$1.0 \mathrm{E}+00$

$1.0 \mathrm{E}+00$

SITE INFORMATION

Temperature: 12 degrees $\mathrm{C}$

Precipitation: $\quad 16 \mathrm{~cm} / \mathrm{y}$

Mixing Height: $1000 \mathrm{~m}$ 
May $9,2000 \quad 10: 38$ am

SYNOPSIS

Page 2

(w 2w 40m set7)

RADIONUCLIDE EMISSIONS DURING THE YEAR

Nuclide

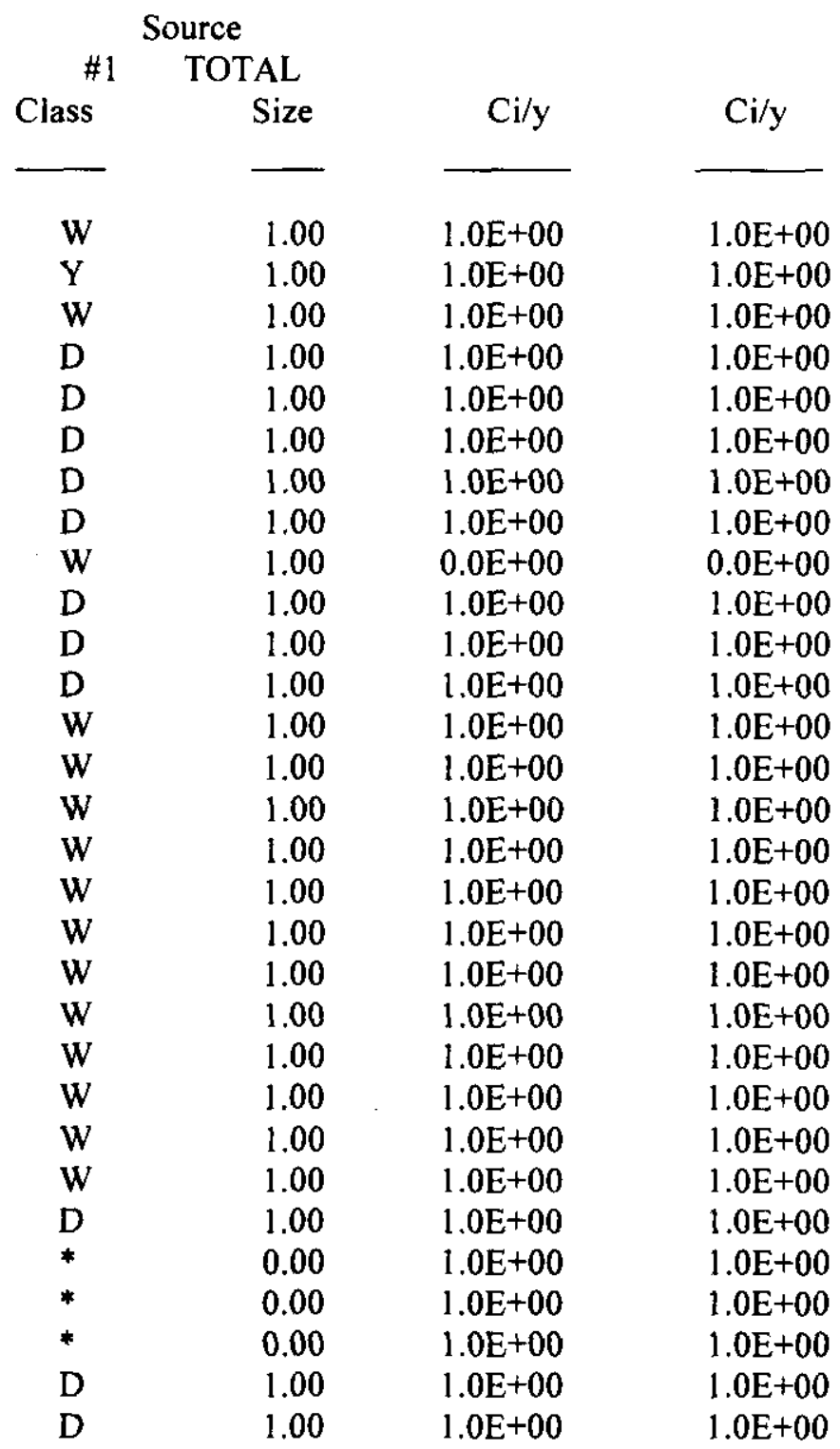

SITE INFORMATION

Temperature: 12 degrees $\mathrm{C}$

Precipitation: $16 \mathrm{~cm} / \mathrm{y}$

Mixing Height: $1000 \mathrm{~m}$ 
May 9,2000 10:38 am

SYNOPSIS

Page 2

(w $2 \mathrm{w} 40 \mathrm{~m}$ set8)

RADIONUCLIDE EMISSIONS DURING THE YEAR

Nuclide

RA-223

RA-224

RA-225

RA-226

RA-228

AC -225

AC -227

AC- 228

TH-227

TH-228

TH-229

TH-230

TH-231

TH-232

RA-228

AC-228

RA-224

RN-220

PO-216

PB-212

BI-212

TL-208

TH-234

PO-218

PA-231

PA-233

PA-234

PA-234M
Source \#1 TOTAL

Class

Size

1.00

1.00

1.00

1.00

1.00

1.00

1.00

1.00

1.00

1.00

1.00

1.00

1.00

1.00

1.00

1.00

1.00

0.00

1.00

1.00

1.00

1.00

1.00

1.00

1.00

1.00

1.00

1.00
$\mathrm{Ci} / \mathrm{y}$$$
1.0 \mathrm{E}+00
$$$$
1.0 \mathrm{E}+00
$$$$
1.0 \mathrm{E}+00
$$$$
1.0 \mathrm{E}+00
$$$$
1.0 \mathrm{E}+00
$$

$1.0 \mathrm{E}+00$

$1.0 \mathrm{E}+00$

$1.0 \mathrm{E}+00$

$0.0 \mathrm{E}+00$

$1.0 \mathrm{E}+00$

$1.0 \mathrm{E}+00$

$1.0 \mathrm{E}+00$

$1.0 \mathrm{E}+00$

$1.0 \mathrm{E}+00$

$0.0 \mathrm{E}+00$

$0.0 \mathrm{E}+00$

$0.0 \mathrm{E}+00$

$0.0 \mathrm{E}+00$

$0.0 \mathrm{E}+00$

$0.0 \mathrm{E}+00$

$0.0 \mathrm{E}+00$

$0.0 \mathrm{E}+00$

$1.0 \mathrm{E}+00$

$1.0 \mathrm{E}+00$

$1.0 \mathrm{E}+00$

$1.0 \mathrm{E}+00$

$1.0 \mathrm{E}+00$

$1.0 \mathrm{E}+00$
$\mathrm{Ci} / \mathrm{y}$

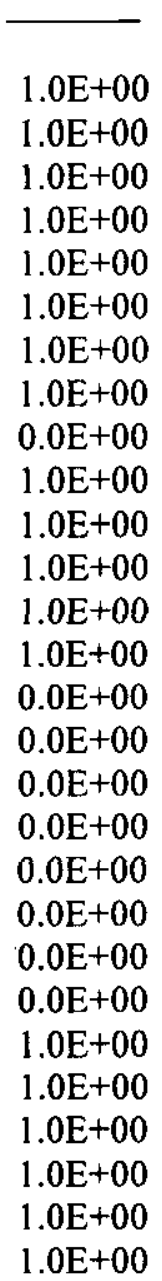

SITE INFORMATION

Temperature: 12 degrees $\mathrm{C}$ Precipitation: $16 \mathrm{~cm} / \mathrm{y}$ Mixing Height: $1000 \mathrm{~m}$ 
May 9,2000 10:38 am

Page 2

SYNOPSIS

(w 2w 40m set9)

\section{RADIONUCLIDE EMISSIONS DURING THE YEAR}

Nuclide

$\mathrm{U}-232$

U. 233

U-234

U-235

$\mathrm{U}-236$

U-237

$\mathrm{U}-238$

TH-234

PA-234

U-234

TH-230

RA-226

RN-222

PO-218

PB-214

BI-214

PO-214

PB-210

BI-210

PO-210

U-240

NP-237

NP-238

NP-239

NP-240

NP-240M

PU-236

PU-238

PU-239

PU-240

PU-241

PU-242

PU-243

PU-244
Source

\begin{tabular}{|c|c|c|c|}
\hline \multicolumn{4}{|c|}{ Source } \\
\hline$\# 1$ & TOTAL & & \\
\hline Class & Size & $\mathrm{Ci} / \mathrm{y}$ & $\mathrm{Ci} / \mathrm{y}$ \\
\hline Y & 1.00 & $1.0 \mathrm{E}+00$ & $1.0 \mathrm{E}+00$ \\
\hline$Y$ & 1.00 & $1.0 \mathrm{E}+00$ & $1.0 \mathrm{E}+00$ \\
\hline Y & 1.00 & $1.0 \mathrm{E}+00$ & $1.0 \mathrm{E}+00$ \\
\hline Y & 1.00 & $1.0 \mathrm{E}+00$ & $1.0 \mathrm{E}+00$ \\
\hline Y & 1.00 & $1.0 \mathrm{E}+00$ & $1.0 E+00$ \\
\hline Y & 1.00 & $1.0 \mathrm{E}+00$ & $1.0 \mathrm{E}+00$ \\
\hline$Y$ & 1.00 & $1.0 \mathrm{E}+00$ & $1.0 \mathrm{E}+00$ \\
\hline $\mathbf{Y}$ & 1.00 & $0.0 \mathrm{E}+00$ & $0.0 \mathrm{E}+00$ \\
\hline Y & 1.00 & $0.0 \mathrm{E}+00$ & $0.0 \mathrm{E}+00$ \\
\hline$Y$ & 1.00 & $0.0 \mathrm{E}+00$ & $0.0 \mathrm{E}+00$ \\
\hline Y & 1.00 & $0.0 \mathrm{E}+00$ & $0.0 \mathrm{E}+00$ \\
\hline W & 1.00 & $0.0 \mathrm{E}+00$ & $0.0 \mathrm{E}+00$ \\
\hline * & 0.00 & $0.0 \mathrm{E}+00$ & $0.0 \mathrm{E}+00$ \\
\hline W & 1.00 & $0.0 \mathrm{E}+00$ & $0.0 \mathrm{E}+00$ \\
\hline D & 1.00 & $0.0 \mathrm{E}+00$ & $0.0 \mathrm{E}+00$ \\
\hline W & 1.00 & $0.0 \mathrm{E}+00$ & $0.0 \mathrm{E}+00$ \\
\hline W & 1.00 & $0.0 \mathrm{E}+00$ & $0.0 \mathrm{E}+00$ \\
\hline D & 1.00 & $0.0 \mathrm{E}+00$ & $0.0 \mathrm{E}+00$ \\
\hline W & 1.00 & $0.0 \mathrm{E}+00$ & $0.0 \mathrm{E}+00$ \\
\hline W & 1.00 & $0.0 \mathrm{E}+00$ & $0.0 \mathrm{E}+00$ \\
\hline $\mathrm{Y}$ & 1.00 & $1.0 \mathrm{E}+00$ & $1.0 \mathrm{E}+00$ \\
\hline $\mathbf{W}$ & 1.00 & $1.0 \mathrm{E}+00$ & $1.0 \mathrm{E}+00$ \\
\hline W & 1.00 & $1.0 \mathrm{E}+00$ & $1.0 \mathrm{E}+00$ \\
\hline W & 1.00 & $1.0 \mathrm{E}+00$ & $1.0 \mathrm{E}+00$ \\
\hline W & 1.00 & $1.0 \mathrm{E}+00$ & $1.0 \mathrm{E}+00$ \\
\hline W & 1.00 & $1.0 \mathrm{E}+00$ & $1.0 \mathrm{E}+00$ \\
\hline $\mathrm{Y}$ & 1.00 & $1.0 \mathrm{E}+00$ & $1.0 \mathrm{E}+00$ \\
\hline$Y$ & 1.00 & $1.0 \mathrm{E}+00$ & $1.0 \mathrm{E}+00$ \\
\hline $\mathrm{Y}$ & 1.00 & $1.0 \mathrm{E}+00$ & $1.0 \mathrm{E}+00$ \\
\hline $\mathrm{Y}$ & 1.00 & $1.0 \mathrm{E}+00$ & $1.0 \mathrm{E}+00$ \\
\hline Y & 1.00 & $1.0 \mathrm{E}+00$ & $1.0 \mathrm{E}+00$ \\
\hline Y & 1.00 & $1.0 \mathrm{E}+00$ & $1.0 \mathrm{E}+00$ \\
\hline$Y$ & 1.00 & $1.0 \mathrm{E}+00$ & $1.0 \mathrm{E}+00$ \\
\hline $\mathrm{Y}$ & 1.00 & $1.0 \mathrm{E}+00$ & $1.0 \mathrm{E}+00$ \\
\hline
\end{tabular}

\section{SITE INFORMATION}

Temperature: 12 degrees $\mathrm{C}$

Precipitation: $16 \mathrm{~cm} / \mathrm{y}$

Mixing Height: $1000 \mathrm{~m}$ 
May 9, $2000 \quad 10: 38$ am

SYNOPSIS

Page 2

(w 2w 40m set10)

RADIONUCLIDE EMISSIONS DURING THE YEAR

Nuclide

AM-241

AM-242

AM-242M

AM-243

$\mathrm{CM}-242$

$\mathrm{CM}-243$

$\mathrm{CM}-244$

CM-245

$\mathrm{CM}-246$

$\mathrm{CM}-247$

CM-248

CF-252

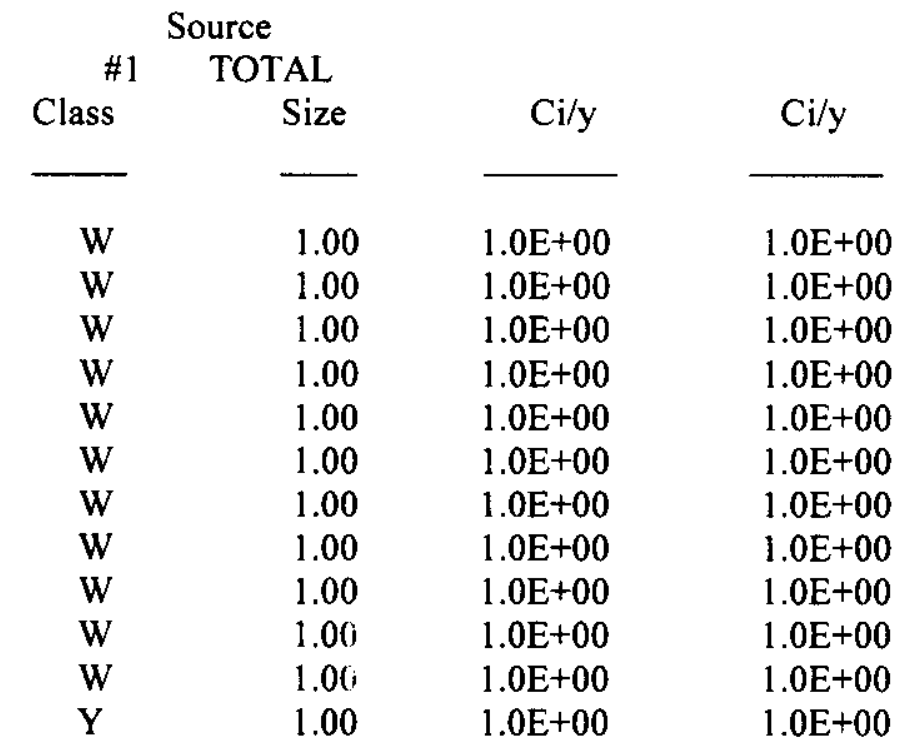

\section{SITE INFORMATION}

Temperature: 12 degrees $\mathrm{C}$

Precipitation: $16 \mathrm{~cm} / \mathrm{y}$

Mixing Height: $1000 \mathrm{~m}$ 
May 9,2000 10:36 am

Page 3

(w 2w 40m set 1 )

\section{SOURCE INFORMATION}

Source Number: 1

Stack Height $(\mathrm{m}): \quad 40.00$

Diameter (m): $\quad 0.00$

\section{SYNOPSIS}

SYNOPSIS

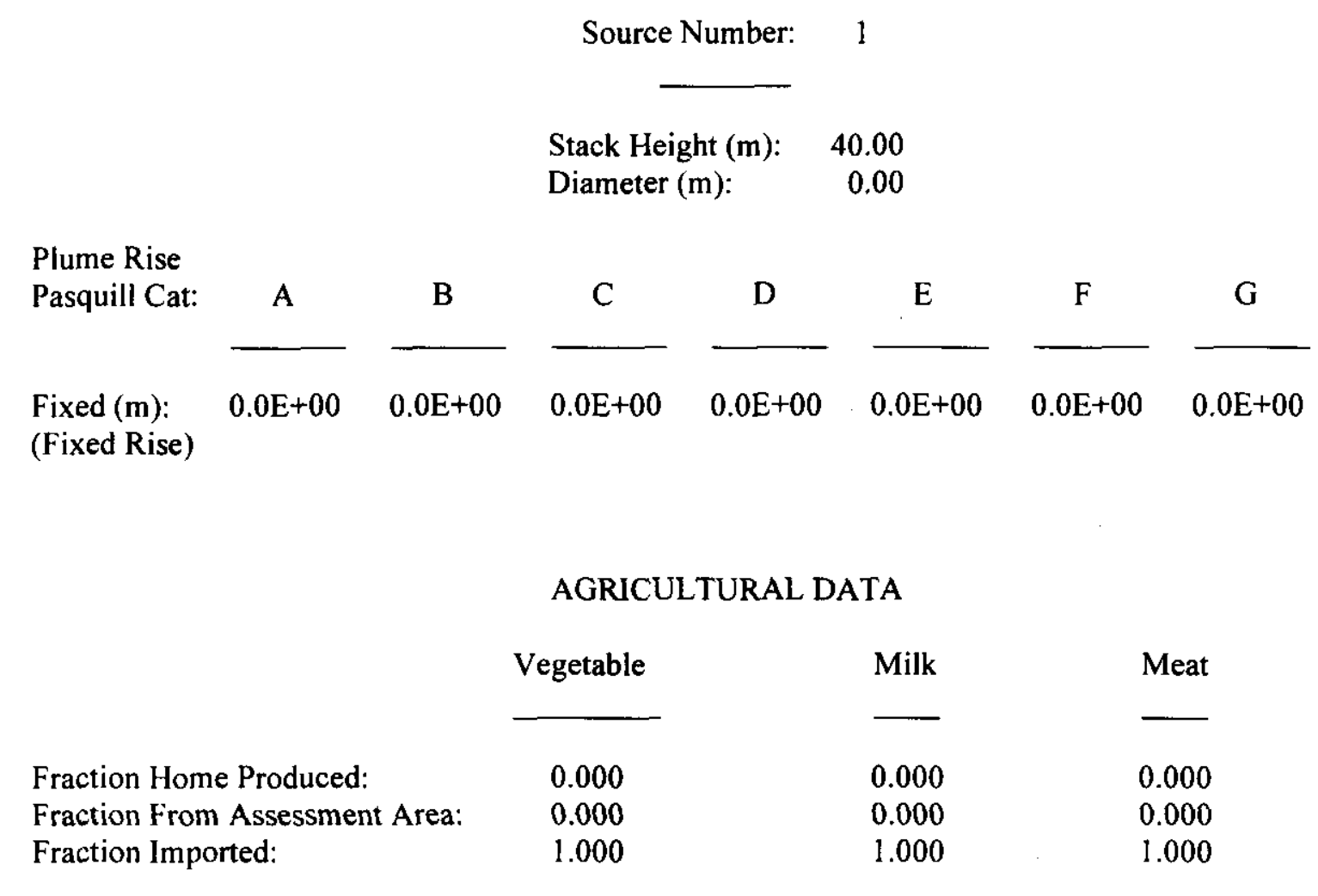

Food Arrays were not generated for this run.

Default Values were used

DISTANCES USED FOR MAXIMUM INDIVIDUAL ASSESSMENT

18310 


\section{DISTRIBUTION}

J. Leitch

United States Environmental Protection Agency

Region 10

1200 Sixth Avenue

Seattle, Washington, 98101

A. W. Conklin

Washington State Department of Health

7171 Cleanwater Lane, Building 5

Olympia, Washington 98504

R. S. Acselrod

Washington State Department of Health

PMB 385

2839 W. Kennewick, Avenue

Kennewick, Washington 99336

Dirk A. Dunning

Oregon Office of Energy

625 Marrian Street N.E., Suite 1

Salem, OR 97301-3742

J. Wilkinson

Confederated Tribes of the Umatilla Indian Nation

P. O. Box 638

Pendleton, Oregon 97801

P. Sobotta

Nez Perce Tribe

P. O. Box 365

Lapwai, Idaho 83540

R. Jim, Manager

Environmental Restoration/Waste Management Program Yakama Nation

P. O. Box 151

Toppenish, Washington 98948

U.S. Department of Energy, Richland Operations Office

P. J. Krupin (2)

A2-15

G. L. Sinton

$\mathrm{H} 0-12$

R. N. Warren

$\mathrm{H} 0-12$

Public Reading Room 


\section{DISTRIBUTION}

MSIN

Fluor Hanford

J. A. Bates

G1-30

R. R. Bloom

T4-51

G. A. Curn

G] -30

L. P. Diediker

G1-27

R. H. Engelmann

G1-30

J. E. Geary

T4-51

C. K. Girres

T3-01

M. F. Hackworth

T4-51

J. E. Hyatt

R. E. Johnson

G1-32

G1-30

N. M. Menard

G1-30

T. Moleff

T4-52

J. C. Sonnichsen

G1-30

J. F. Williams

G1-30

N. P. Willis

T4-52

AOP File

G1-30

Pacific Northwest National Laboratory

Hanford Technical Library

P8-55

Lockheed Martin Services, Inc.

Central Files

B1-07

DPC

H6-08

$\operatorname{EDMC}(2)$

H6-08 